WHOI $-82-40$

BEACH CHANGES AT NAUSET INLET, CAPE COD, MASSACHUSETTS

$1670-1981$

by

P. E. Speer, D. G. Aubrey, and

E. Ruder

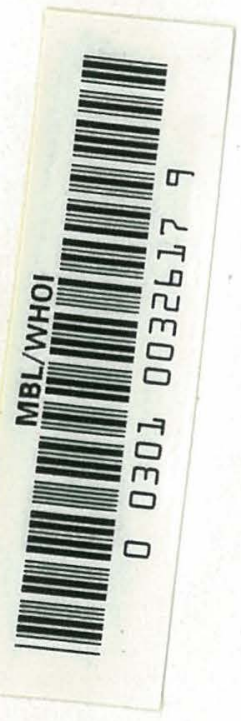

WOODS HOLE OCEANOGRAPHIC INSTITUTION
Woods Hole, Massachusetts 02543

August 1982

TECHNICAL REPORT

Prepared for NOAA, Office of Sea Grant under Grant NA 80-AA-D$00077(R / B-21)$ and for the U.S. Army Research Office under Grant DAAG29-81-K-0004.

Reproduction in whole or in part is permitted for any purpose of the United States Government. This report should be cited as: woods Hole Oceanog. Inst. Tech. Rept. WHOI-82-40.

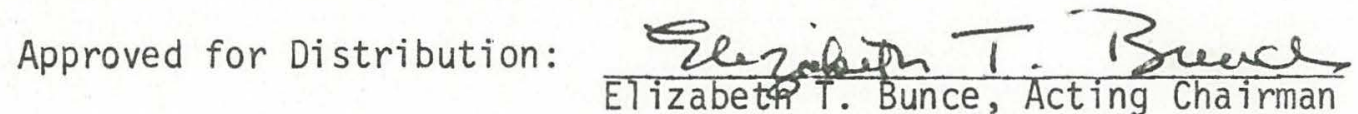
Geology and Geophysics Department 


\section{BEACH CHANGES AT NAUSET INLET, CAPE COD, MASSACHUSETTS 1670-1981}

By

$$
\begin{gathered}
\text { P.E. Speer 1, D.G. Aubrey 1, and E. Ruder } 2 \\
\text { July, } 1982
\end{gathered}
$$

1 Woods Hole Oceanographic Institution, Woods Hole, MA 02543 (U.S.A.)

2 Wesleyan University, Middletown, CT 06457 (U.S.A.) 


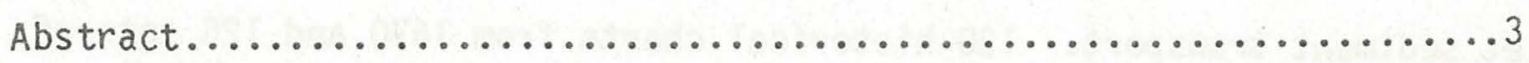

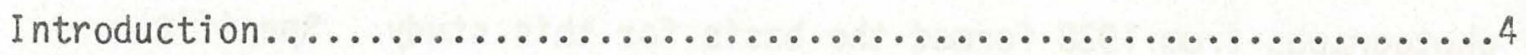

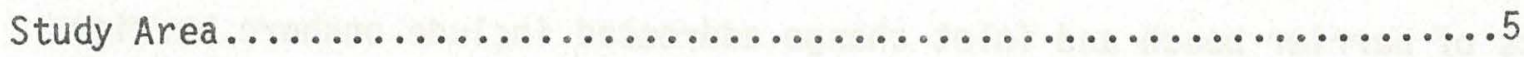

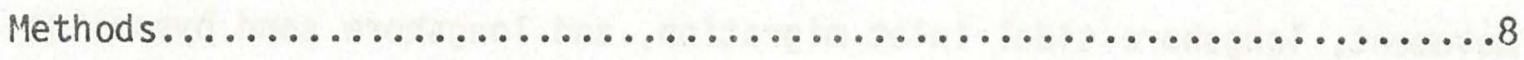

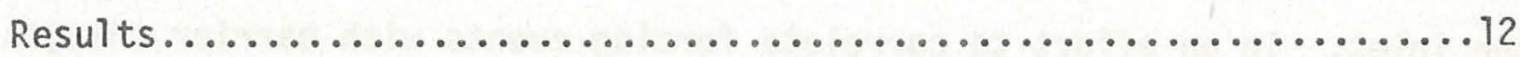

a. Longshore intet/barrier beach migration................

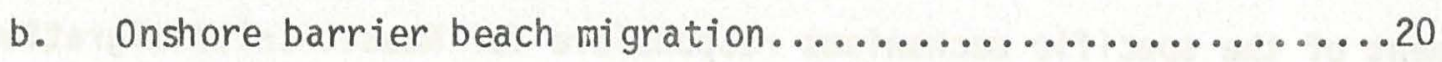

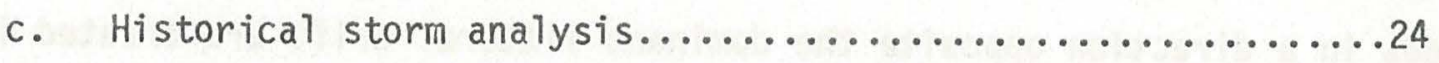

d. Bar bypassing of longshore sediment transport.............. 32

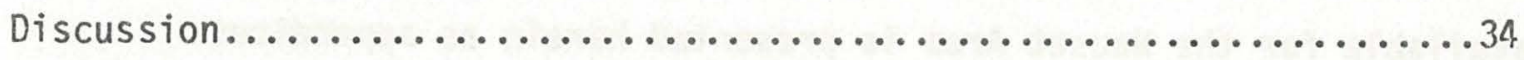

a. Longshore inlet migration models.....................

b. Future trends in longshore inlet migration.............

c. Onshore migration of barrier beach and

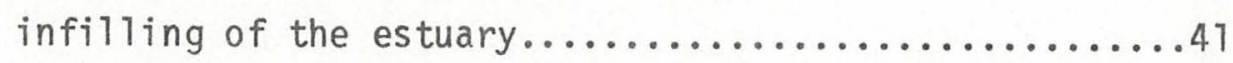

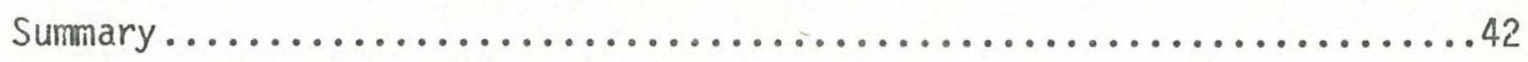

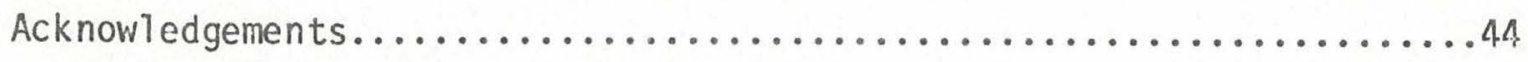

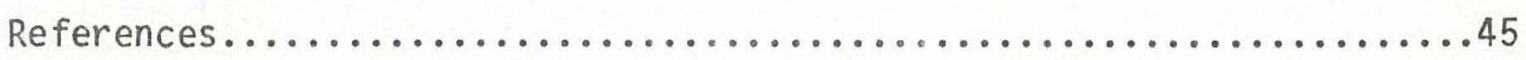

Appendices

1. Historical charts $(1670-1978) \ldots \ldots \ldots \ldots \ldots \ldots \ldots \ldots \ldots$

2. Historical photographs $(1938-1981) \ldots \ldots \ldots \ldots \ldots \ldots \ldots$

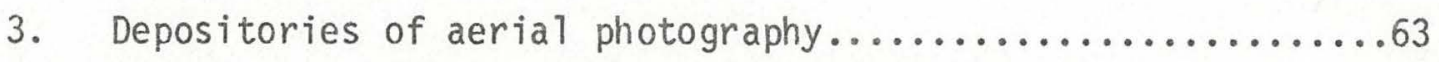

4. Tracings of selected historical maps and photographs.......66 


\section{ABSTRACT}

A historical study of barrier beach and inlet changes for the Nauset Inlet region, Cape Cod, Massachusetts, was performed to document patterns of beach and inlet change as a preliminary to designing and carrying out field studies of inlet sediment transport. 120 historical charts from 1670 and 125 sets of aerial photographs from 1938 formed the basis for this study. Specific aspects of barrier beach and inlet change addressed include onshore barrier beach movement, longshore tidal inlet migration, and longshore sand bypassing past the inlet. In an effort to correlate forcing events with barrier changes, an exhaustive study of the local storm climate was performed. Detsiled treatment of the specific mechanisms responsible for Nauset Inlet migration episodes in a direction opposite the dominant littoral drift are treated in a companion paper by Aubrey, Speer, and Ruder (1982). Documentation of the data base available for the Nauset Area is presented herein as appendices. 
This document presents the results of an historical survey of barrier beach changes at Nauset InTet, MA. Onshore barrier movement, tidal inlet migration, and bypassing events are al1 discussed in this document. Data on which this work was based are presented as several appendices.

Migration of tidal inlets and the associated changes in adjacent barrier beaches have profound implications on both the geological evolution of inlet/ estuary systems and the short-term stability of these features. Past studies have documented many instances of inlets migrating in the direction of net littoral drift along sandy shores, but have uncovered few cases (e.g., Indian River, Delaware, and Thorsminde Inlet, Denmark) where inlets appear to migrate in directions opposed to the dominant longshore transport direction (Bruun, 1978). Migration of tidal inlets in a direction opposite to littoral drift increases the incidence of inlet-induced changes in the estuary (specifically filling in the estuary with littoral sands derived from updrift sources, as flood tide delta growth accompanies the migration of the inlet). The freedom to migrate in an updrift direction causes marsh development (colonization and plant emergence) to become more variable and less permanent.

Previous attempts to explain the reversal in direction of inlet migration suggest a change in direction of net littoral drift, causing a change in migration direction. This explanation is not realistic for some inlets where wave forcing and nearshore bathymetry have remained constant through time. This study presents three alternatives to explain the tendency of some inlets to migrate updrift, each supported by historical observations at a site with a large-volume, directional7y-biased littoral drift. 


\section{STUDY AREA}

The study site is located on the Atiantic coast of Cape Cod, Massachusetts (figure 1), exposed to open ocean waves from the east and a two-meter ocean tide. Offshore bathymetry and sediments are described elsewhere (Aubrey, Twichell and Pfirman, 1982). Nearshore sediments are described by Wright (1978) and Wright and Brenninkmeyer (1979). Longshore transport rates and directions were studied by Zeigler (1954, 1960), and net littoral drift has been estimated at $250,000 \mathrm{~m}^{3}$ per year towards the south (U.S. Army Corps of Engineers, 1969). Sediment is derived from erosion of sea cliffs bordering Nauset Inlet to the north.

Overwash processes along Nauset barrier beaches are described in Zaremba and Leatherman (1982). Aubrey and Speer $(1981,1982)$ discuss tidal flows and velocity asymmetries in the bay. Other sedimentologic studies of the general area can be found in a summary volume by Leatherman (1981).

Sea level in this area is rising at an average rate of about $3 \mathrm{~mm} / \mathrm{year}$ (based on tidal data at two nearby stations, Table 1). This rate is three times greater than the mean sea level rise of one mm/year over the past 2100 years estabiished from measurements of salt marsh peat accumulation at Barnstable Harbor, Cape Cod (Redfield and Rubin, 1962). As discussed by Emery (1980) and others, even short-term mean sea level records show considerable oscillations about a mean trend; thus the present increased rate of sea level rise may represent just a short-term oscillation superimposed on the slower 2100 year trend. Sea level rise favors landward migration of developing barrier beaches. 


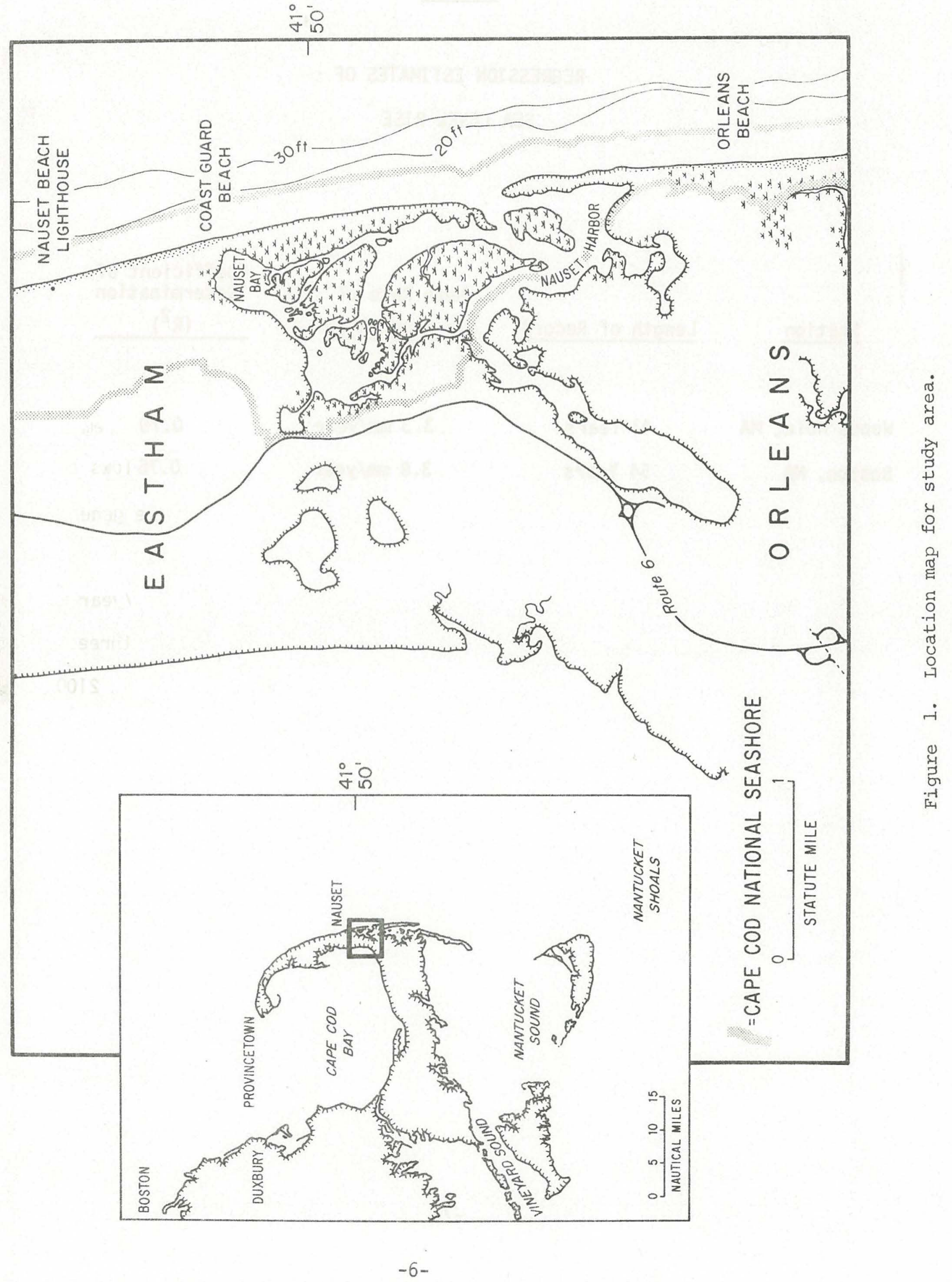


TABLE 1

\section{REGRESS ION EST IMATES OF}

SEA LEVEL RISE

Mean Rate of

Station Length of Record Sea Level Rise

Woods Hole, MA

Boston, MA
43 Years

54 Years
$3.3 \mathrm{~mm} /$ year

$3.8 \mathrm{~mm} /$ year
Coefficient of Determination $\left(R^{2}\right)$ 
Historical charts and aerial photographs of the Nauset Inlet area dating from 1670 and 1938, respectively, were examined to define and (where possible) quantify changes in inlet and shoreline position and morphology. Historical data (figure 2) were obtained from a variety of sources including government agencies, the National Archives, the Library of Congress, the Woods Hole Oceanographic Institution, and private industry (Apendices 1 and 2). Chart coverage is dense from 1790 to present (coverage was sparse before 1790), and good aerial photographic coverage exists from 1951 to present (only one aerial photo sequence was available prior to 1951 , taken in 1938).

Smal1 scale and uncertain mapping techniques used in pre-1846 historical charts make it difficult to quantify changes in inlet morphology during this period, but these charts are valuable in depicting general trends in intet morphology. Care was required in interpreting the charts because several of the charts from the 1800 's did not specify survey dates, and are merely reproductions of earlier and perhaps outdated surveys. Also, in the case of U.S. Coast and Geodetic Survey (USCaGS) charts, only limited shoreline segments were updated between editions.

Aerial photographs provide more detailed information than the charts because they are generally larger in scale (allowing resolution of shoreline features such as bars and marshes). They also provide more comprehensive temporal coverage for a limited period (1951 to 1981) than do the charts, and the dates of coverage are unambiguous. Fifty vertical sets of the 125 photographs available were measured to quantify inlet and spit migration at Nauset. The remaining photographs were not measured because they were taken 


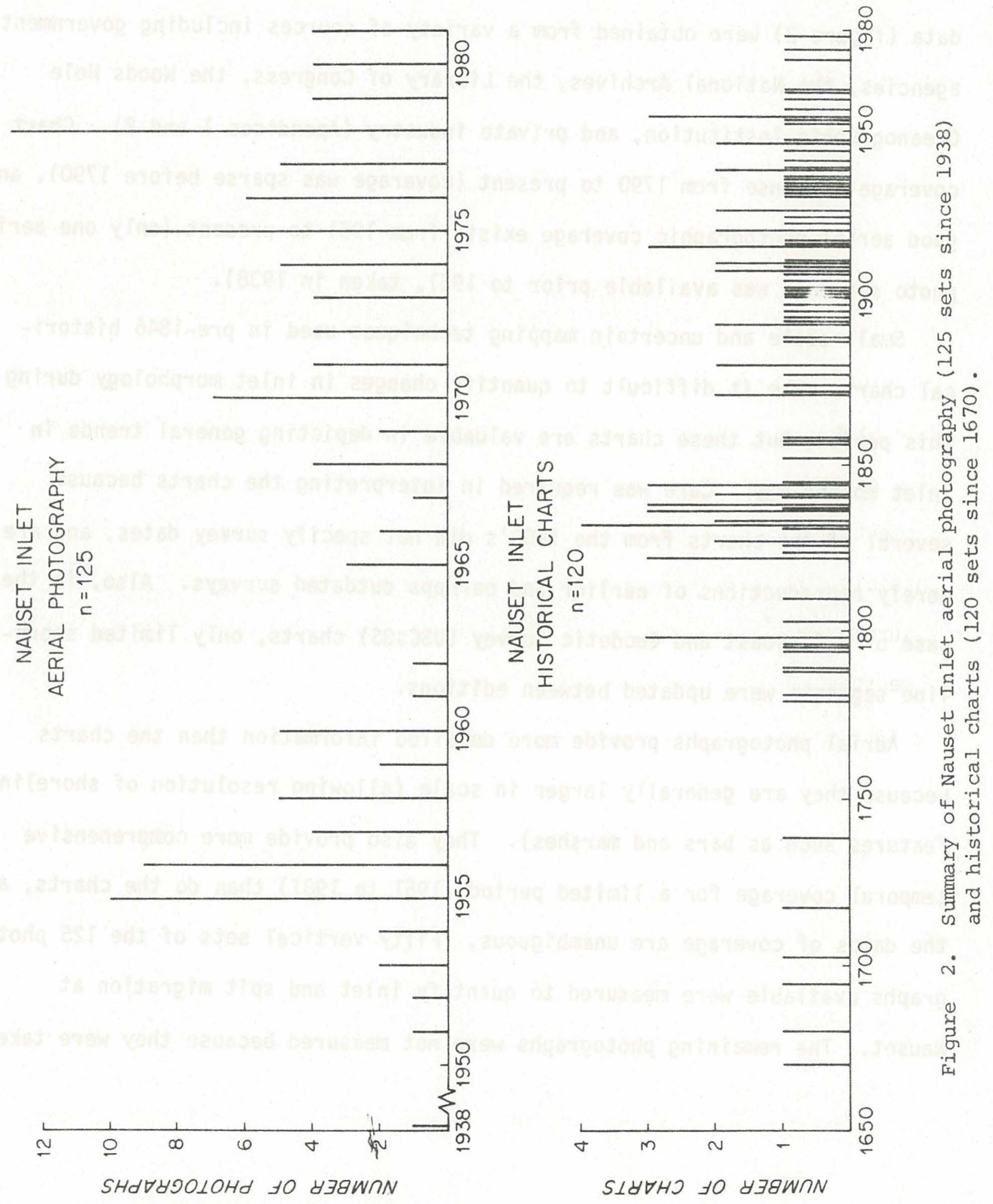


at oblique angles, were poorly fitted mosaic series, or lacked sufficient ground control to assure measurement accuracy. They were, however, instrumental in providing a continuous record of relative changes in inlet and spit locations during the past 30 years.

Measurements of shoreline, spit and inlet location are relative to a baseline, sub-parallel to the shoreline, established between well-defined, permanent features identified on each set of aerial photographs (Figure 3). The known length of this baseline provided a consistent determination of scale for all photos. Shoreline was measured at each of ten evenly-spaced stations between the reference points. Shoreline location was defined as the perpendicular distance from the baseline station to the waterline. Measurement to the high tide line would be preferred, but variations in photo resolution, due to differing degrees of exposure, environmental conditions and photographic equipment, make accurate and consistent location of the high tide line impossible. Estimates of tidal stage for each photo (based on observations of exposure of marshes, offshore bars and tidal deltas) were incorporated into the measurements of shoreline and inlet location. The majority of photographs were taken at or near low water, presumably to allow for better resolution of intertidal features.

Additional uncertainty in some measurements results when one of the two primary reference points is absent from the particular photo mosaic. In these cases, secondary landmarks are used along with geometrical relations to define the baseline from the one available endpoint. As a result of such variations in the photographs, overall accuracy of measurements is estimated to be $\pm 15 \mathrm{~m}$, despite a measurement resolution of $5 \mathrm{~m}$. 


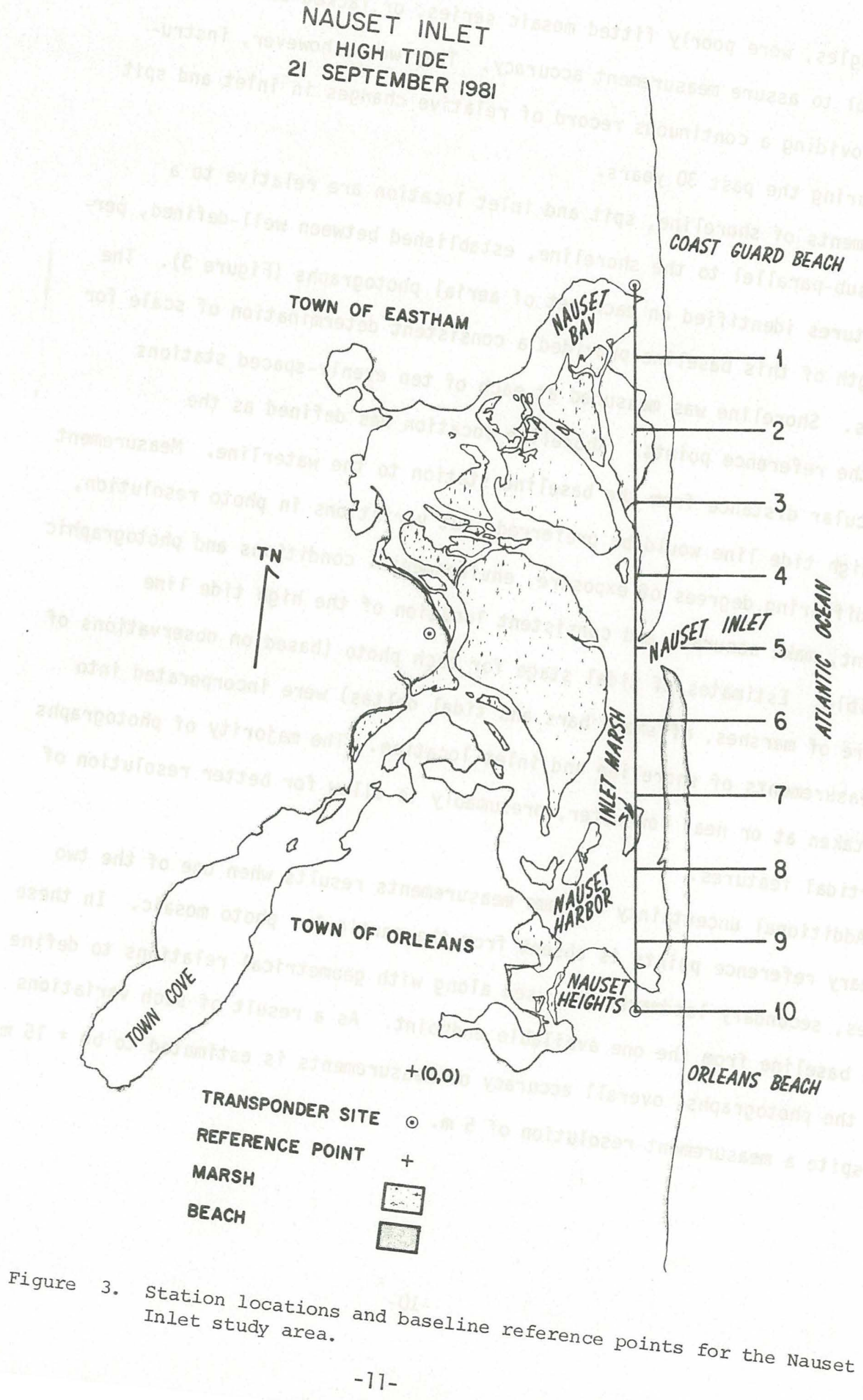


No allowances or corrections were made for seasonal variations in beach profiles and sea level, which can alias a high-frequency variation into lower-frequency trends. Measurements of seasonal mean sea level (MSL) intercept migrations along this beach show an average winter shoreward displacement of about $30 \mathrm{~m}$ compared to the summer position (Miller and Aubrey, 1982). This is partly balanced by an estimated $30 \mathrm{~cm}$ steric sea level drop in the winter (Emery and Uchupi, 1972). Neglecting profile readjustment, a $30 \mathrm{~cm}$ vertical change translates to a $7 \mathrm{~m}$ horizontal seasonal change in MSLintercept, with a seaward motion in the winter.

\section{RESULTS}

Analysis of historical charts and photographs reveals patterns of inlet migration and barrier beach elongation/shortening at Nauset. Two specific problems were addressed in the historical analysis: inlet migration with accompanying barrier beach changes and onshore/offshore barrier beach migration. The analysis has also provided insight into patterns for bypassing longshore sediment transport past a tidal inlet. Finally, the storm climate at Cape Cod was compiled for correlation with major inlet migration episodes. LONGSHORE INLET/BARR IER BEACH MIGRATION

Historical charts (dating from 1779) and aerial photography (dating from 1938) show the preferred inlet location to have been just north of Nauset Heights, at the southern (downdrift) extremity of the bay drainage system. Subject to limitations imposed by sparse historical coverage (figure 2), the charts indicate that prior to the 1950's Nauset Inlet consistently has been immediately north of Nauset Heights (figure 4). No charts examined to 1946 reveal a significant south spit. Previous episodes of inlet migration may be undersampled by aperiodic historical coverage. The persistence of the southern location, however, suggests this is an historically stable inlet configuration. 


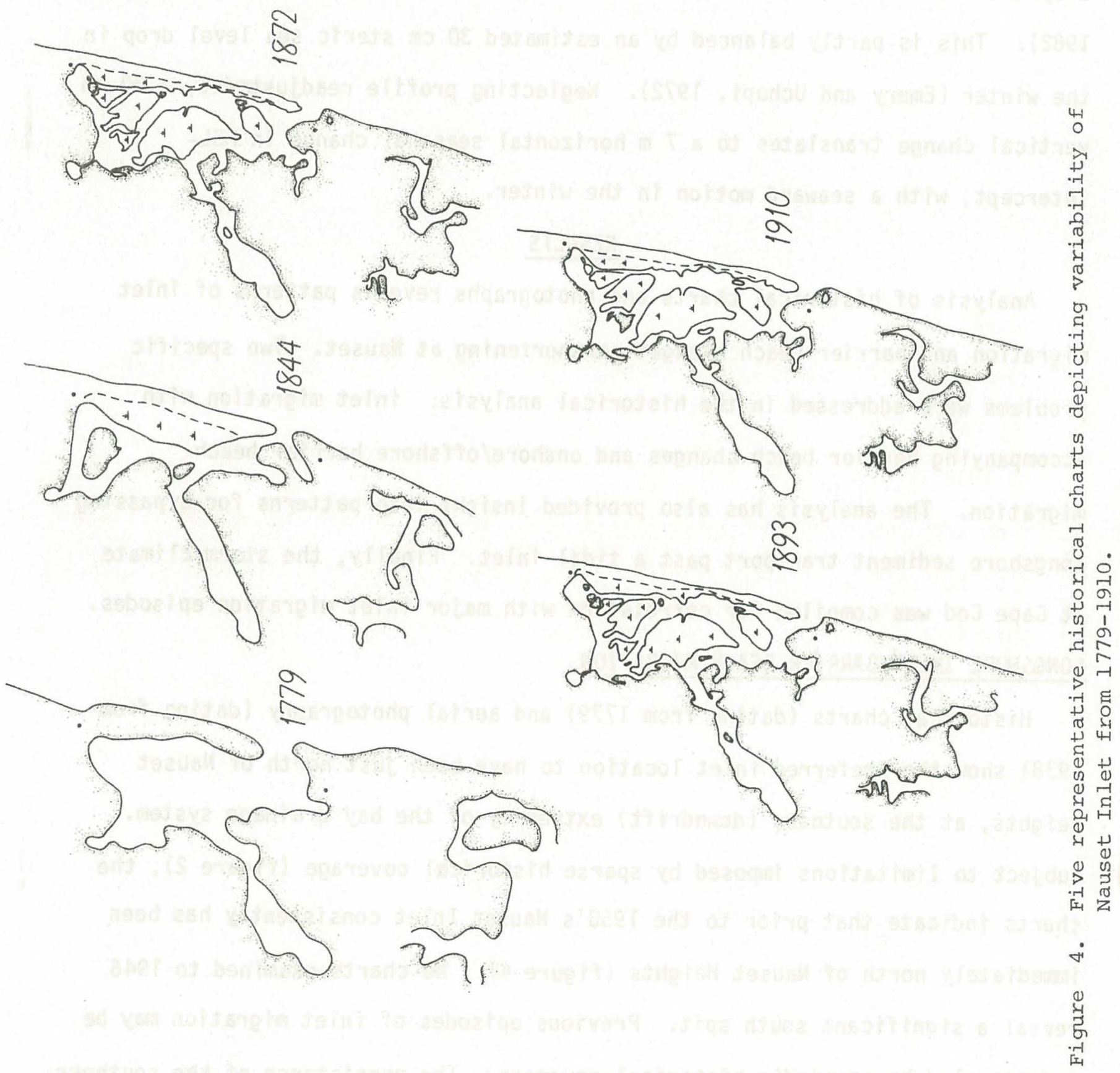


Two peculiar features depicted in the earliest charts are missing in later charts: a channel connecting Pleasant Bay to Nauset Harbor, and multiple inlets in the north barrier beach. Pleasant Bay is a bay to the south of Nauset which drains into Nantucket Sound and the Atlantic Ocean. The 1779 Des Barres chart is the first showing the Pleasant Bay channel. Charts from 1781 , 1795, 1798 and 1810 (Appendix 4) also show this channel. It apparently filled in between 1810 and 1832. Vestiges exist today as a marshy region and a smal1 pond west of Orleans Beach below Nauset Heights. If deep enough, the connection to the large drainage system of Pleasant Bay may have had significant impact on inlet stability. Three charts $(1779,1781,1795)$ show three openings in the north barrier beach. It is not clear whether these openings were semipermanent inlets or simply large overwashes through the dune line. Aside from temporary and very shallow storm breaches, no other instances of multiple inlets have been noted.

A 1938 aerial photograph places the inlet just north of Nauset Heights, with no south barrier apparent (figures 5, 6a). No photographs exist for the 1940 's; however, a 1946 U.S.G.S. chart shows the inlet still in this location (figure 6b). From the 1950's into the early 1980's, the intet has been very active, with several cycles of migration culminating in a recent steady, northward movement.

Between 1946 and October 1951, the southern spit lengthened $800 \mathrm{~m}$ north from the headlands at Nauset Heights. This growth was most likely the result of a storm breaching the north spit (figure $6 c$ ). The northern spit eroded 690 m over this same period. In 1952, a breach developed on the north spit, shortening it by approximately $420 \mathrm{~m}$. A marshy island (Inlet Marsh; figures $3,6 a)$, formerly located behind the north spit, was exposed to the ocean (figure $6 \mathrm{~d}$ ). During this period, the south spit remained in the same 


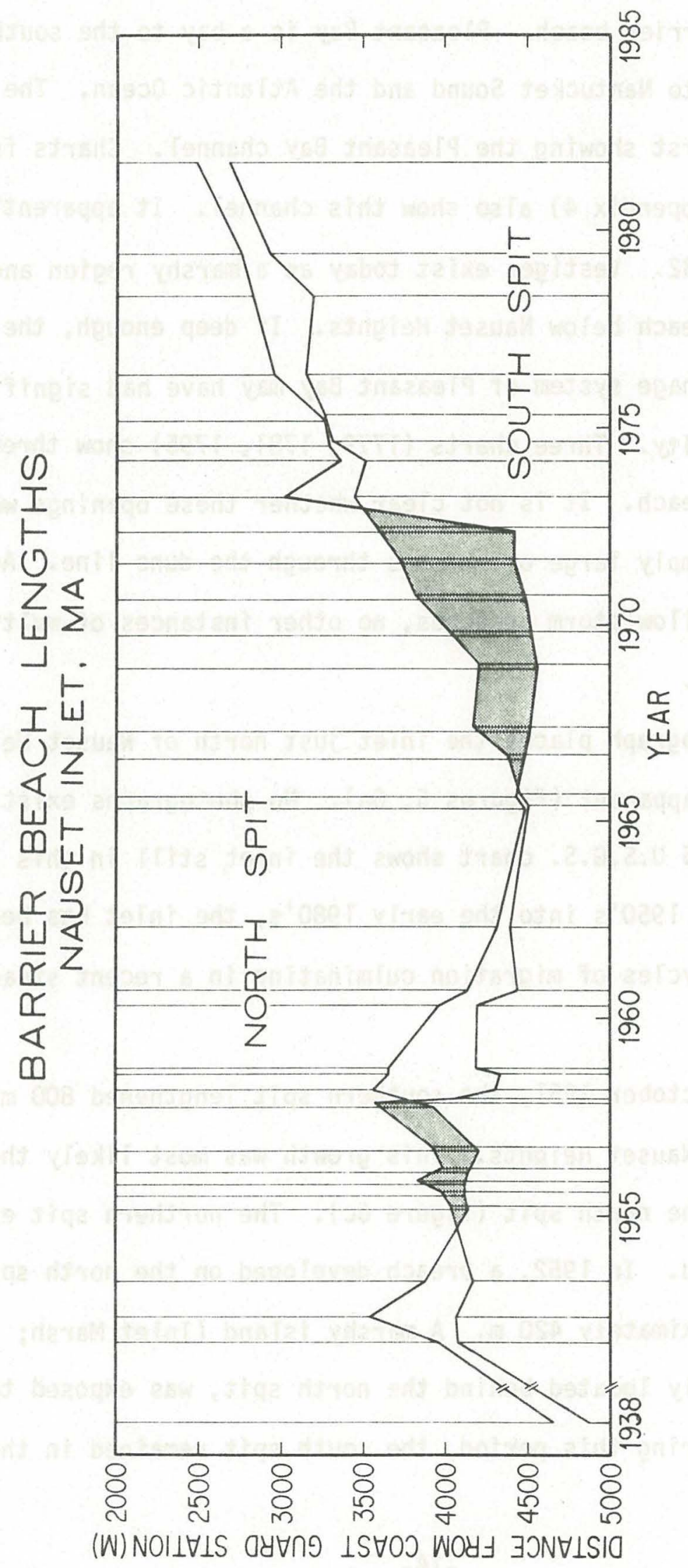

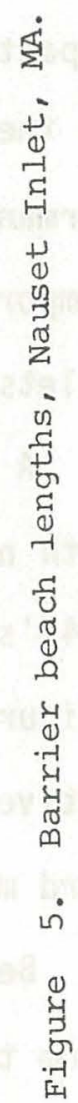



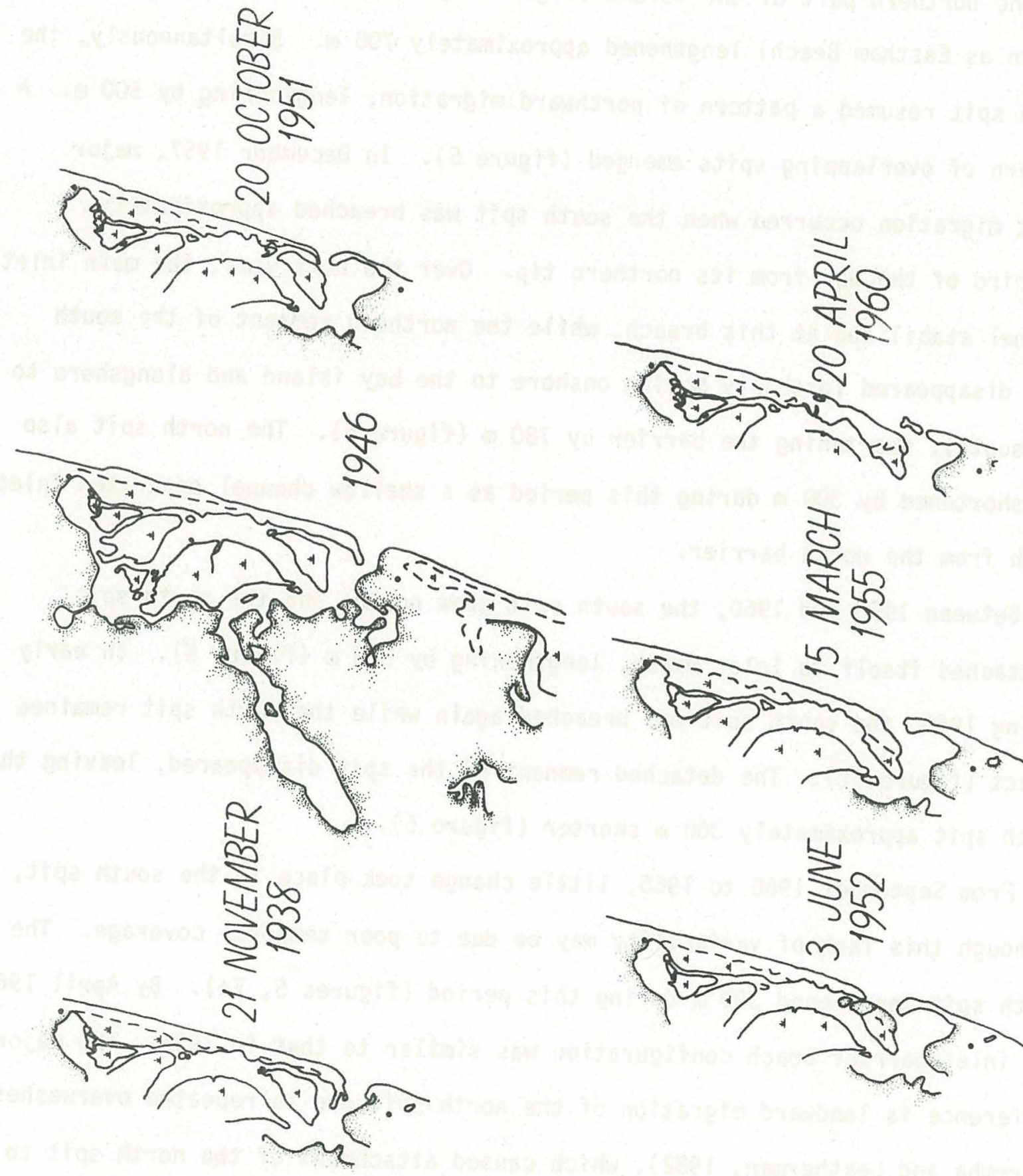

0
0
0
3
0
0
+1
0
-1
5
1
+1
0
0
7
7
$z$
4
0
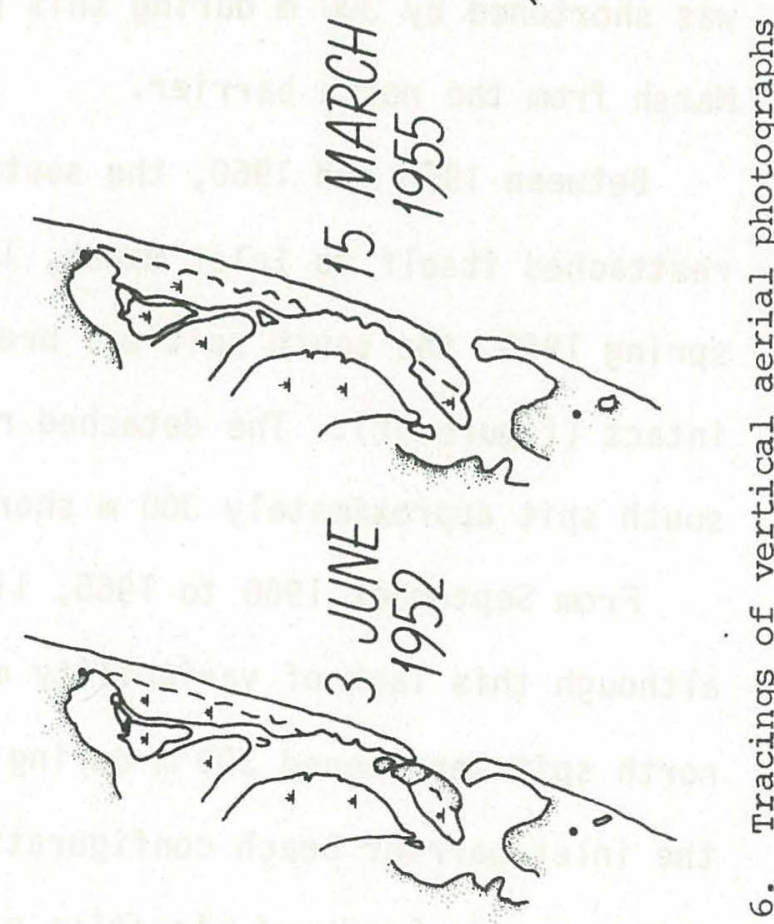

$+$

30
40

. 0 न

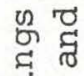

엄

स्मेन

ம்

苟 
location, as did the main inlet channel. From 1952 to 1957, the north spit grew southward and attached itself to the bay island (Inlet Marsh), as longshore transport closed a shallow channel which had separated the barrier and the northern part of the island (figures 5, 6e). The resultant beach (known as Eastham Beach) 1engthened approximately $700 \mathrm{~m}$. Simultaneously, the south spit resumed a pattern of northward migration, lengthening by $500 \mathrm{~m}$. A pattern of overlapping spits emerged (figure 5). In December 1957, major inlet migration occurred when the south spit was breached approximately on-third of the way from its northern tip. Over the next year, the main inlet channel stabilized at this breach, while the northern remnant of tho south spit disappeared (probably moving onshore to the bay island and alongshore to the south), shortening the barrier by $780 \mathrm{~m}$ (figure 5). The north spit also was shortened by $300 \mathrm{~m}$ during this period as a shallow channel separated Inlet Marsh from the north barrier.

Between 1958 and 1960, the south spit grew north, and the north spit reattached itself to Inlet Marsh, lengthening by $500 \mathrm{~m}$ (figure 5). In early spring 1960, the south spit was breached again while the north spit remained intact (figure $6 \mathrm{f}$ ). The detached remnant of the spit disappeared, leaving the south spit approximately $300 \mathrm{~m}$ shorter (figure 5 ).

From September 1960 to 1965, little change took place in the south spit, aithough this lack of variability may be due to poor temporal coverage. The north spit lengthened $300 \mathrm{~m}$ during this period (figures 5, 7a). By Apri1 1965, the inlet/barrier beach configuration was similar to that in 1938 . The major difference is landward migration of the north spit due to repeated overwashes (Zaremba and Leatherman, 1982), which caused attachment of the north spit to the marsh island (Inlet Marsh), originally separated by a narrow channel. From 

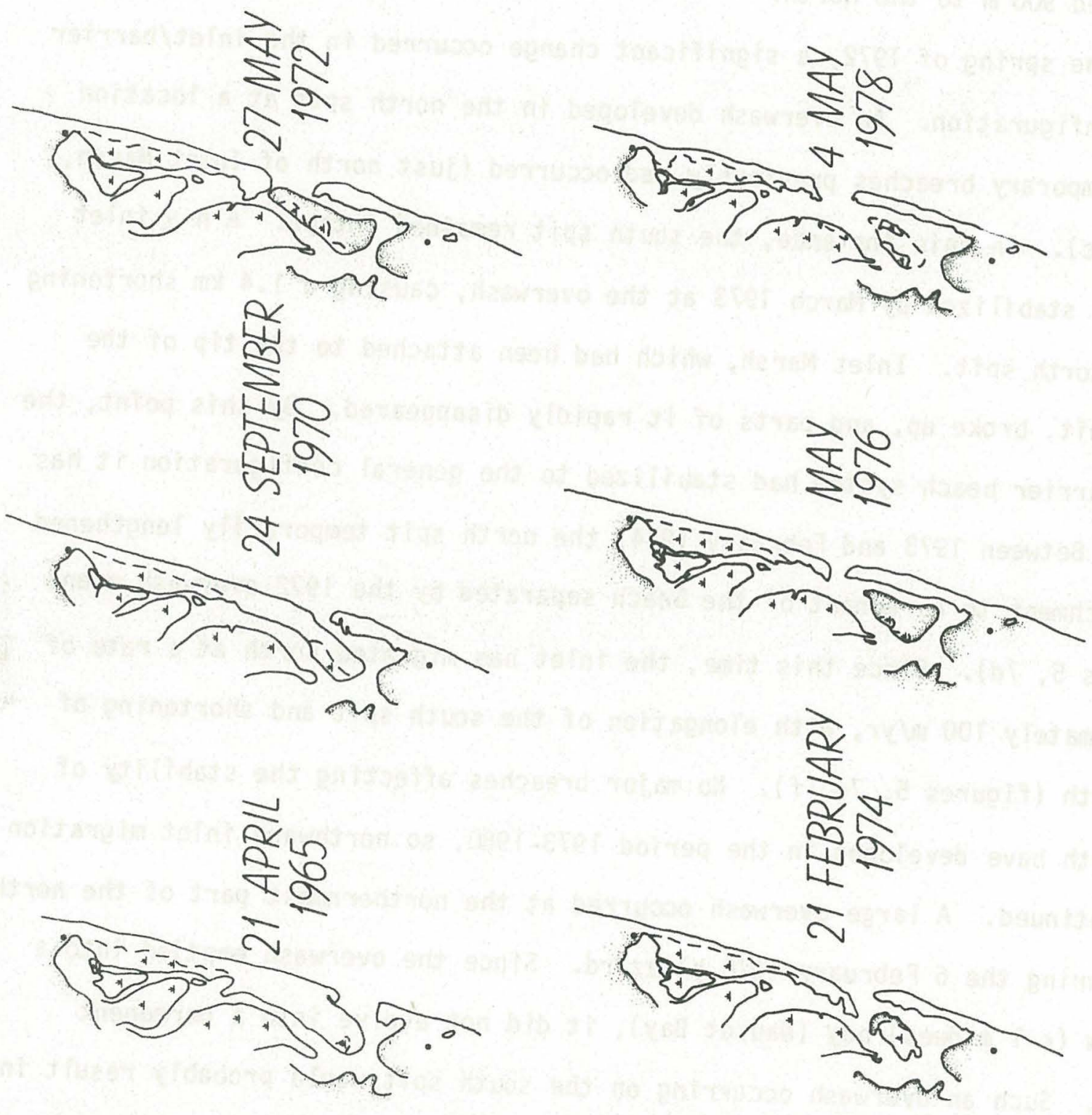
1965 to 1972, the pattern of barrier overlap observed in the 1950's again repeated. The south spit grew nearly $900 \mathrm{~m}$ during this period, while the north spit remained approximately the same length (figures 5, 7b). The main inlet channel, while maintaining its base at the 1965 position, consequently lengthened $900 \mathrm{~m}$ to the north.

In the spring of 1972, a significant change occurred in the inlet/barrier beach configuration. An overwash developed in the north spit at a location where temporary breaches previously had occurred (just north of Inlet Marsh, figure 7c). In this instance, the south spit remained intact. A n v inlet location stabilized by March 1973 at the overwash, causing a $1.4 \mathrm{~km}$ shortening of the north spit. Inlet Marsh, which had been attached to the tip of the north spit, broke up, and parts of it rapidly disappeared. By this point, the inlet/barrier beach system had stabilized to the general configuration it has today. Between 1973 and February 1974, the north spit temporarily lengthened by attachment to a remnant of the beach separated by the 1972 overwash event (figures 5, 7d). Since this time, the inlet has migrated north at a rate of approximately $100 \mathrm{~m} / \mathrm{yr}$, with elongation of the south spit and shortening of the north (figures $5,7 \mathrm{e}, \mathrm{f}$ ). No major breaches affecting the stability of the south have developed in the period 1973-1980, so northward inlet migration has continued. A large overwash occurred at the northernmost part of the north spit during the 6 February 1978 blizzard. Since the overwash emptied into a shallow ( $1 \mathrm{~m}$ deep) bay (Nauset Bay), it did not evolve into a permanent breach. Such an overwash occurring on the south spit would probably result in a new inlet location. 
Changes in shoreline position at ten stations spaced at equal intervals of $535 \mathrm{~m}$ along the photographic baseline (figure 3) were documented by analysis of vertical photographs. The analysis shows onshore spit migration to be highly variable in both location and time (figure 8). For the purposes of discussion, the stations are divided into three groups: station 1-5, all on the north spit; stations 6-8, in areas of inlet migration; and stations 9 and 10, south of the inlet.

Stations 1-4 show a coherent picture of shoreline changes over time. A11 four show a seaward movement of the barrier during the period 1951-1953, followed by a relatively stable position up to 1956. The magnitude of the growth from 1951 to 1953 ranged from $50 \mathrm{~m}$ at station 1 to approximately $100 \mathrm{~m}$ at station 4. At station 4, a further $50 \mathrm{~m}$ seaward migration occurred through December 1957. A similar seaward growth at stations 1-3 is suspected though there were problems making accurate measurements for these stations. This pattern of migration may be partly explained by seasonal differences in mean water level. A landward migration of the shoreline took place at the four stations from 1958 to 1962 . The retreat was approximately $100 \mathrm{~m}$ at station 4 and as much as $190 \mathrm{~m}$ at station 1. The period 1962 to 1972 showed 1 ittle net change in shoreline position. Since 1972, shoreline position has retreated landwards from $40 \mathrm{~m}$ to $80 \mathrm{~m}$ at these stations, especially noticable at stations 1, 3, and 4 (Table 2). Excursions of the shoreline both seaward and landward on the order of 40-50 m occur during this period and, in the case of station 2, obscure any trend in the 1970's. For most of this time period, station 5 shows similar trends to stations 1-4. Seaward migration from 1951 to 1953 of $75 \mathrm{~m}$ was followed by a stable period until March 1955. The shoreline then retreated 1 andward (with oscillations) $130 \mathrm{~m}$ up to March 1962 . From 


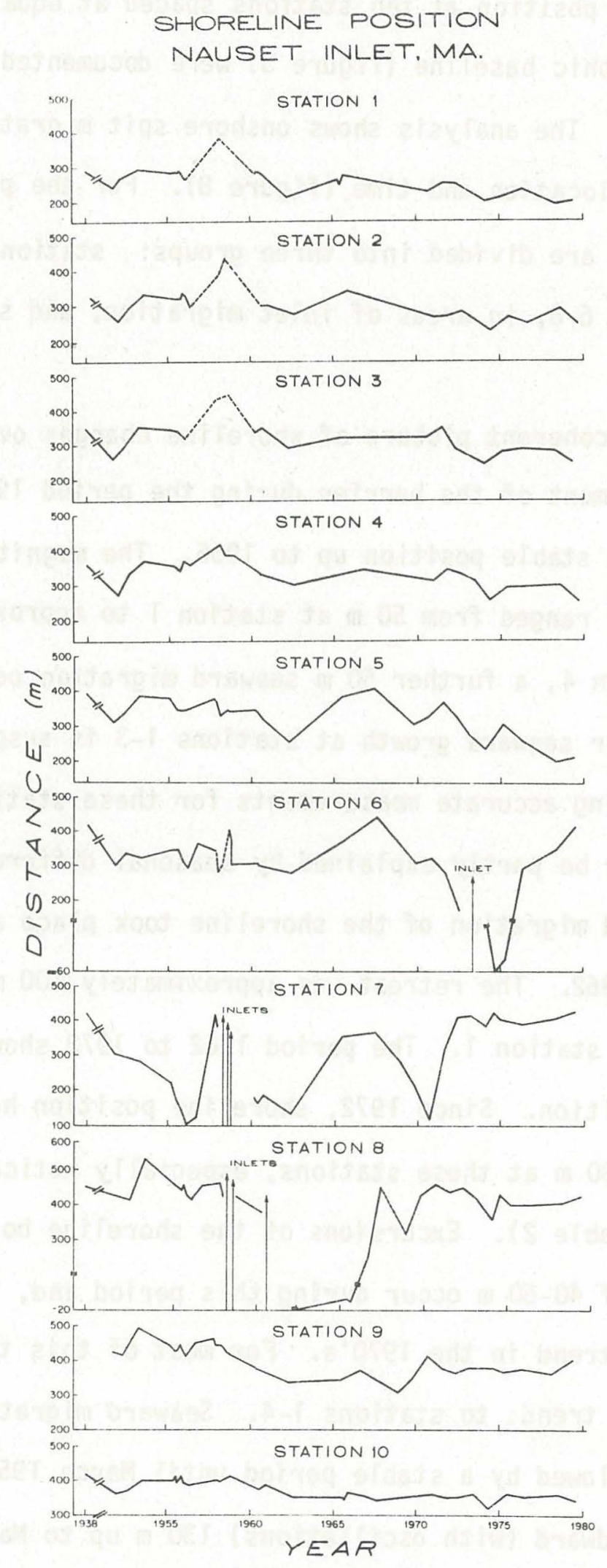

Figure 8. Shoreline position, Nauset Inlet, MA. 


\section{REGRESS ION ESTIMATES OF SHOREL INE POS ITION}

STATION

1

2

3

4

5

6

7

8

9

10 $\frac{\text { SLOPE }}{\left(\frac{m / y e a r}{)}\right)}$

$-2.5$

$-1.7$

$-1.7$

$-2.3$

$-3.6$

$-5.3$

$-4.7$

$-2.0$

$-3.3$

$-2.0$
INTERCEPT

412

405

416

480

553

624

457

504

605

502
$\mathrm{R}^{2}$

0.61

0.25

0.28

0.35

0.42

0.18

0.15

0.02

0.42

0.57 
1962 to 1967, the shoreline moved seaward $160 \mathrm{~m}$. The period 1967 to May 1979 has seen a shoreline retreat of approximately $240 \mathrm{~m}--\mathrm{a}$ rate of nearly $20 \mathrm{~m} / \mathrm{yr}$. Again, large excursions of the shoreline $(\sim 75 \mathrm{~m})$ over shorter time scales are superimposed on this general trend.

Stations 6-8 (especially 7 and 8) show a complicated picture of onshore/ offshore spit migration since they are in the region of active inlet movement. This is particularly true until the period following 1972 . Stations 7 and 8 have been on the south spit in the period 1973-1982 and shoreline position has been stable. Station 6 has displayed a trend of seaward migration in shoreline since 1975, amounting to approximately $400 \mathrm{~m}$. The large chanc?s in shoreTine position for all these stations may be attributed to rapid beach erosion or accretion of sand bars during periods of inlet migration.

Stations 9 and 10 are the southernmost lines measured. In 1938 station 9 was located in the inlet, but it has been part of the south spit since the early 1950's. Station 10 is located south along Nauset Heights and has not been directly affected by episodes of inlet migration. A general onshore migration of the south spit occurred at station 9 from 1953 to 1968, with a net shoreline displacement of $190 \mathrm{~m}$, followed by a seaward migration of approximately $105 \mathrm{~m}$ from 1968 to 1971. Since 1972, no real trend in onshore/ offshore migration has been observed at this station. Little net change in shoreline position occurred at station 10 during this study. In the 1950's, the shoreline was essentially stable. From 1958 to 1962 , it retreated landward approximate $7 y 50 \mathrm{~m}$. Since 1962, it has shown no strong tendency for either onshore or offshore migration. 
The Atlantic shore of Cape Cod is frequently buffeted by storms which have the potential to cause dramatic changes in shoreline configuration. A U.S. Army Corps of Engineers report (1979) cites 160 gales with wind speeds greater than 32 mph between 1870-1975. Half of these were northeasters. Both tropical and extra-tropical (including northeasters) cyclones produce dramatic changes at Nauset Inlet because of the geographical orientation of the outer Cape.

Three types of storm data were collected for comparison with large-scale morphologic changes at Nauset (documented by aerial photos):

a) Hayden and Smith (1982) compiled a monthly list of cyclone occurrences off the east coast between 1885 and 1982, using as a data base the "Tracks of the Centers of Cyclones at Sea Level" published by Monthly Weather Review and in recent years by Mariners Weather Log. Cyclone statistics (both tropical and extra-tropical) are available on $2.5^{\circ}$ latitude by $5^{\circ}$ longitude grid cells. The four grid cells bordering the Cape Cod region to the east and southeast (total area covered is $60^{\circ} \mathrm{W}$ to $70^{\circ} \mathrm{W}, 371 / 2^{\circ} \mathrm{N}$ to $421 / 2^{\circ} \mathrm{N}$ ) are used as the region of storm influence for the study area. For generation of year-by-year and monthly mean statistics, storm values for the four grid cells are summed. Al though this yields an overestimate of the number of storms (the same storm may pass more than one grid cell), it will still provide a qualitative indication of storm duration and persistence, since on the average a storm tracking through two grid cells generates waves in the study area for a longer period of time than one passing a single grid cell.

Cyclone statistics resulting from the averaging serve as a crude indicator of wave activity. Large cyclone counts suggest high wave activity; a small 
cyclone count represents low wave activity. Persistence and frequency of storms are our criteria for wave intensity. Clearly storm intensity or magnitude would be a useful weighting factor for linking waves and storms; unfortunately, this information is not available.

Monthly mean storm frequency over the 96 year period (Figure 9) shows the expected result that storm incidence is highest in the winter (Jan., Feb. and March) and lowest in the late spring and summer (June through September). These data can also be combined to yield annual number of storms since 1885 (Figure 10). The period from 1885 through 1949 experienced a relat ely low incidence of storm activity. Within this low background level, the periods from 1885-1893, 1921-1924, and 1930-1941 have 1ocal maxima in cyclone frequency. The last thirty years of the record show consistentiy higher cyclone frequency, with 1ocal maxima at 1950-1954, 1961-1962, 1972 and 1974. A1 though the absolute number of storms may be sensitive to the quality and quantity of weather observation stations, local trends (minima and maxima) are valid indicators of relative storm occurrence.

b) Another source of storm incidence data was the U.S. Army Waterways Experiment Station (WES) wave hindcast program (data provided by $W$. Birkemeier). This program computes nearshore wave height statistics based on weather observations and local bathymetry. The study identified the 157 largest storm events from 1956 to 1976 (inclusive). These storms were assigned recurrence intervals according to their rankings, allowing for weighting of storms by severity. The WES compilation (Figures 11 and 12) correlates well with cyclone data. Relative seasonal values are similar, but the difference between summer and winter storm activity is much greater in the W.E.S. modeling than in the cyclone 


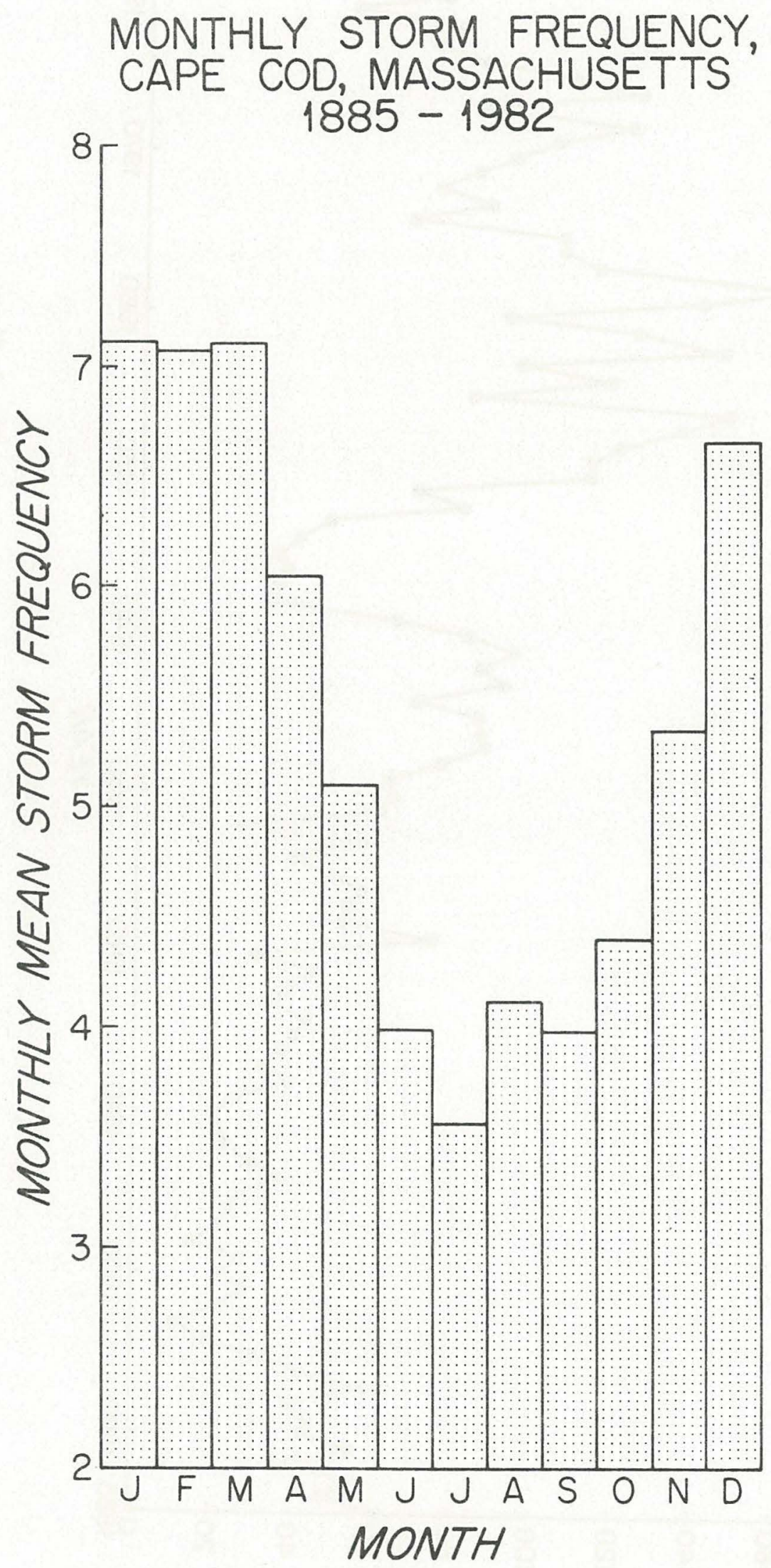

Figure 9. Mean monthly cyclone frequency off Cape cod, Massachusetts (including area $60^{\circ} \mathrm{W}$ to $70^{\circ} \mathrm{W}, 37 \frac{1}{2}^{\circ} \mathrm{N}$ to $42 \frac{1}{2}^{\circ} \mathrm{N}$ ), from Hayden and Smith (1982). 


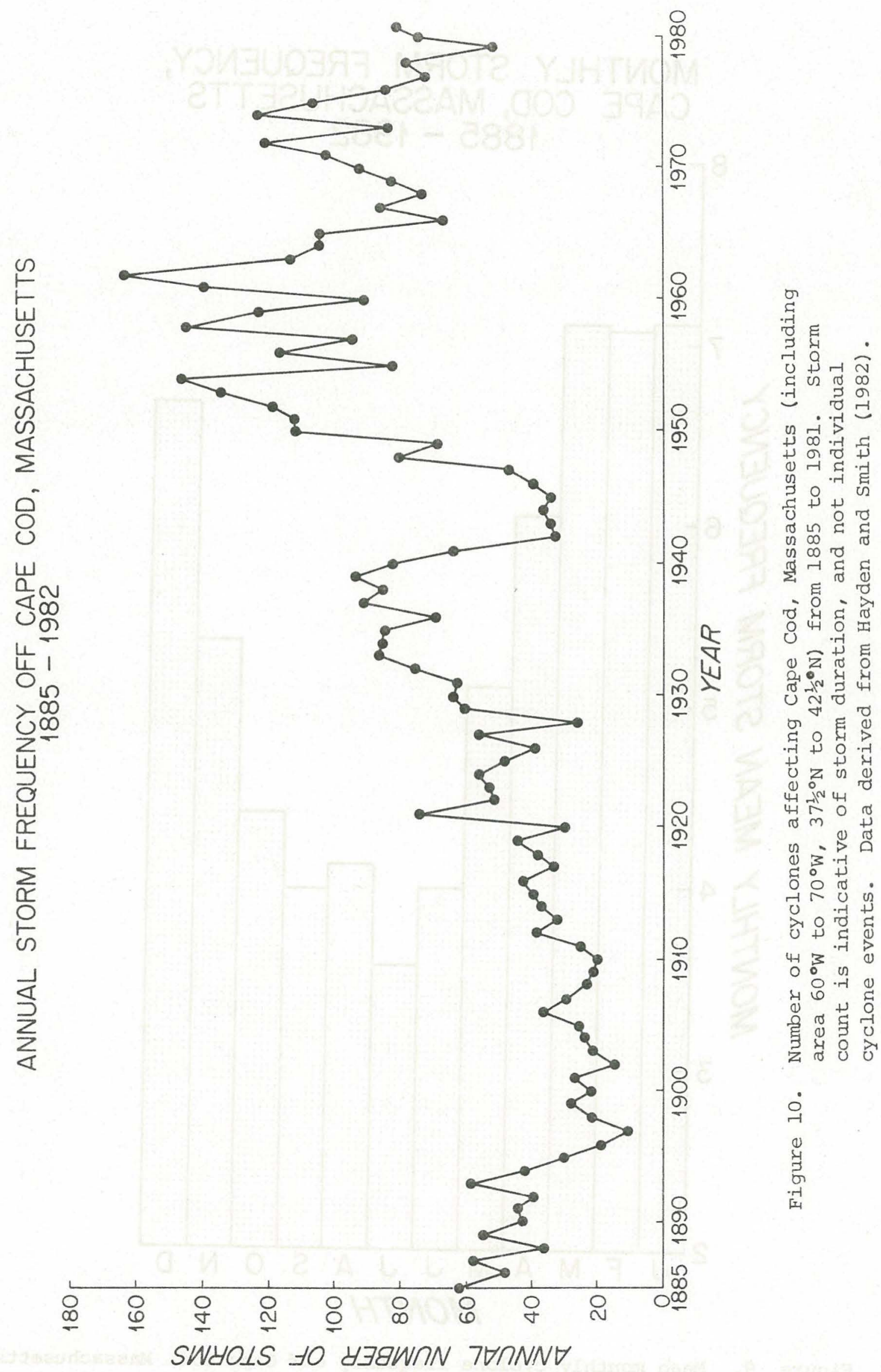




\section{SEASONAL STORM RECURRENCE INTERVALS $1956-1975$}

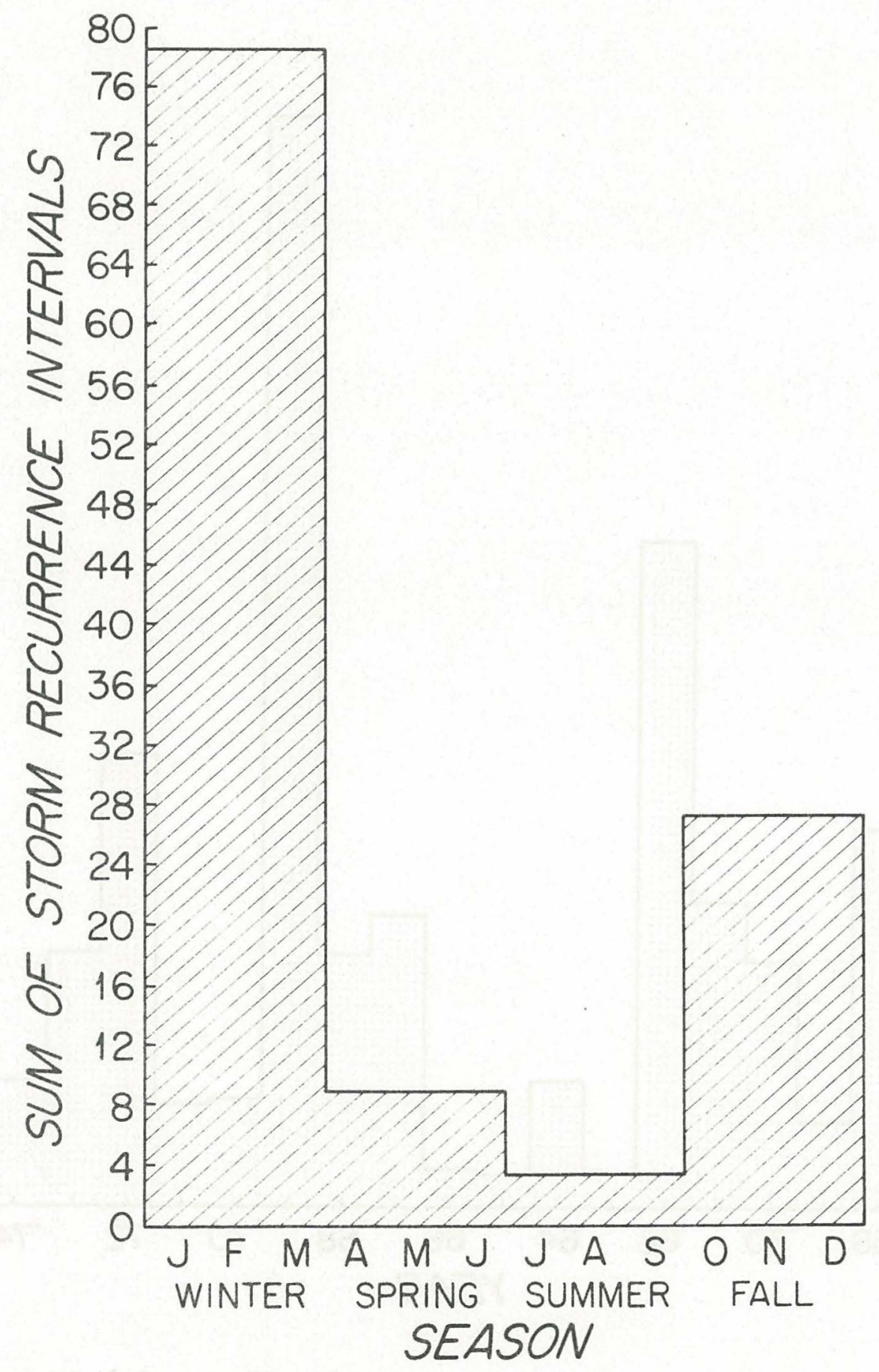

Figure 11. Seasonal storm activity as indicated by storm recurrence intervals for period 1956-1975. Data from W.E.S. compilation. 


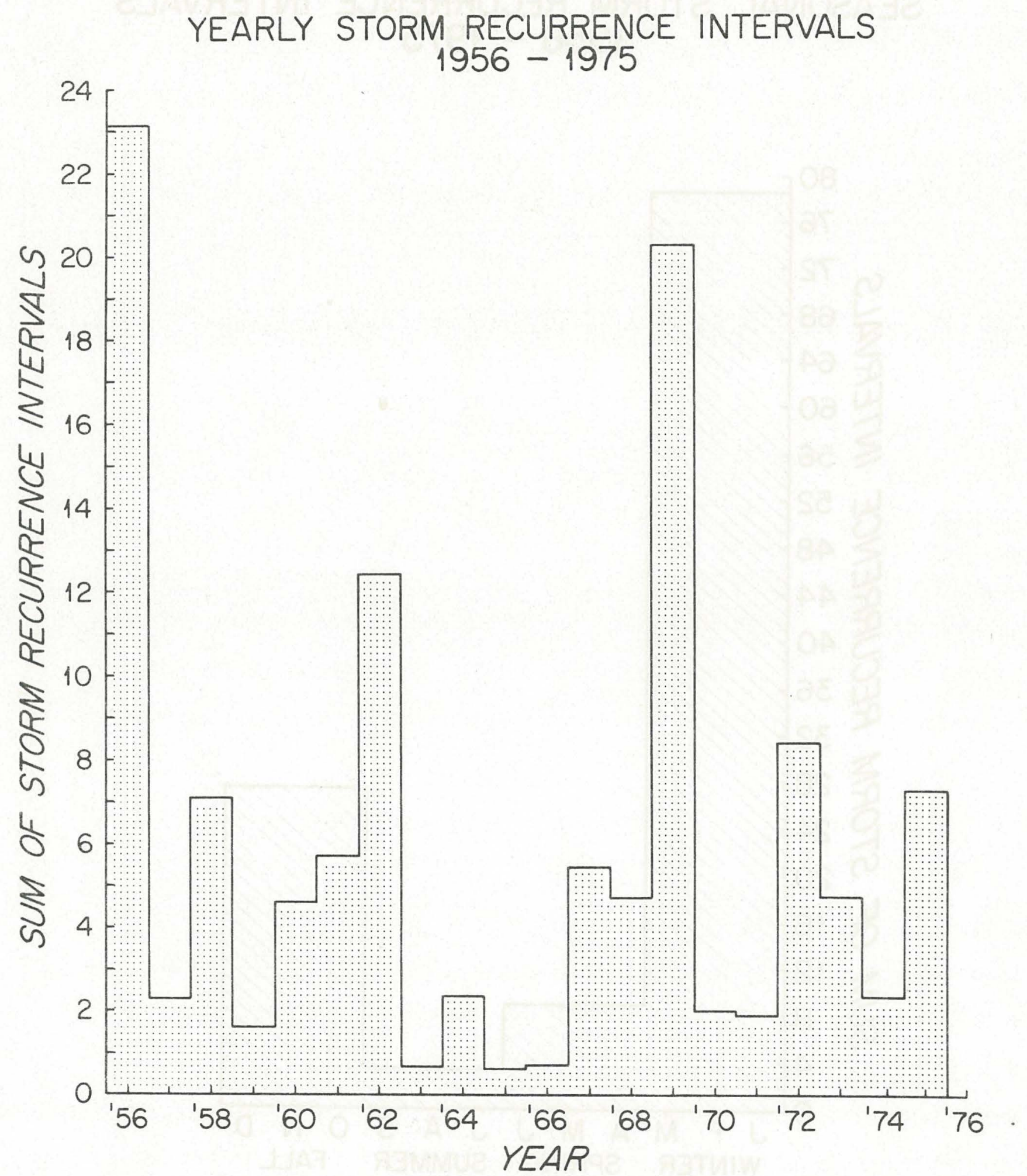

Figure 12. Yearly storm activity from 1956-1976 off Cape Cod, Massachusetts, determined by W.E.S. hindcast. 
statistics. W.E.S. data show high storm activity in 1956, 1962, and 1972; however, it also indicates a high level of storm activity in 1969 which does not appear in cyclone data. Differences between the two data sets are the result both of weighting procedures and different representations of the data base.

c) Finally, a list of major storms affecting the outer Cape was compiled from newspapers, historical descriptions, and published tropical storm tracks (Figure 13). This list is incomplete since prior to 1948 it only includes hurricanes and storms of historical significance. It is possible to identify specific storms which are likely to cause changes at Nauset Inlet, al though irregular sampling afforded by aerial photography (figure 2) makes direct correlation difficult. Through this method, ten significant storms were found that were not hindcast in the WES study.

The importance of storm activity to major changes in inlet/barrier beach configuration is illustrated by comparison of inlet migration with storm frequency. Historical data (figures 10, 12, 13) show three periods of high storm activity since 1933, preceded by a 48 year period of relative quiescence. The first period of intense activity lasted from 1933 until 1939. Unfortunately, inadequate chart or photo coverage prevents documentation of the response to this stormy period. The second period of high storm activity couvered the years 1950 to 1962. Large scale inlet migration, together with overwash and breaching of the barrier beaches, occurred during this time. Breaches developed through the north barrier during May 1953 and January 1956, and through the south barrier during December 1957 and early spring 1960. Storm-induced changes in barrier beach length of as much as $780 \mathrm{~m}$ have been noted. A third period of intense storm activity existed in the early 1970's. One of the peak years, 1972, coincides with a breach in the north spit, which initiated the current phase of steady northward inlet migration. 


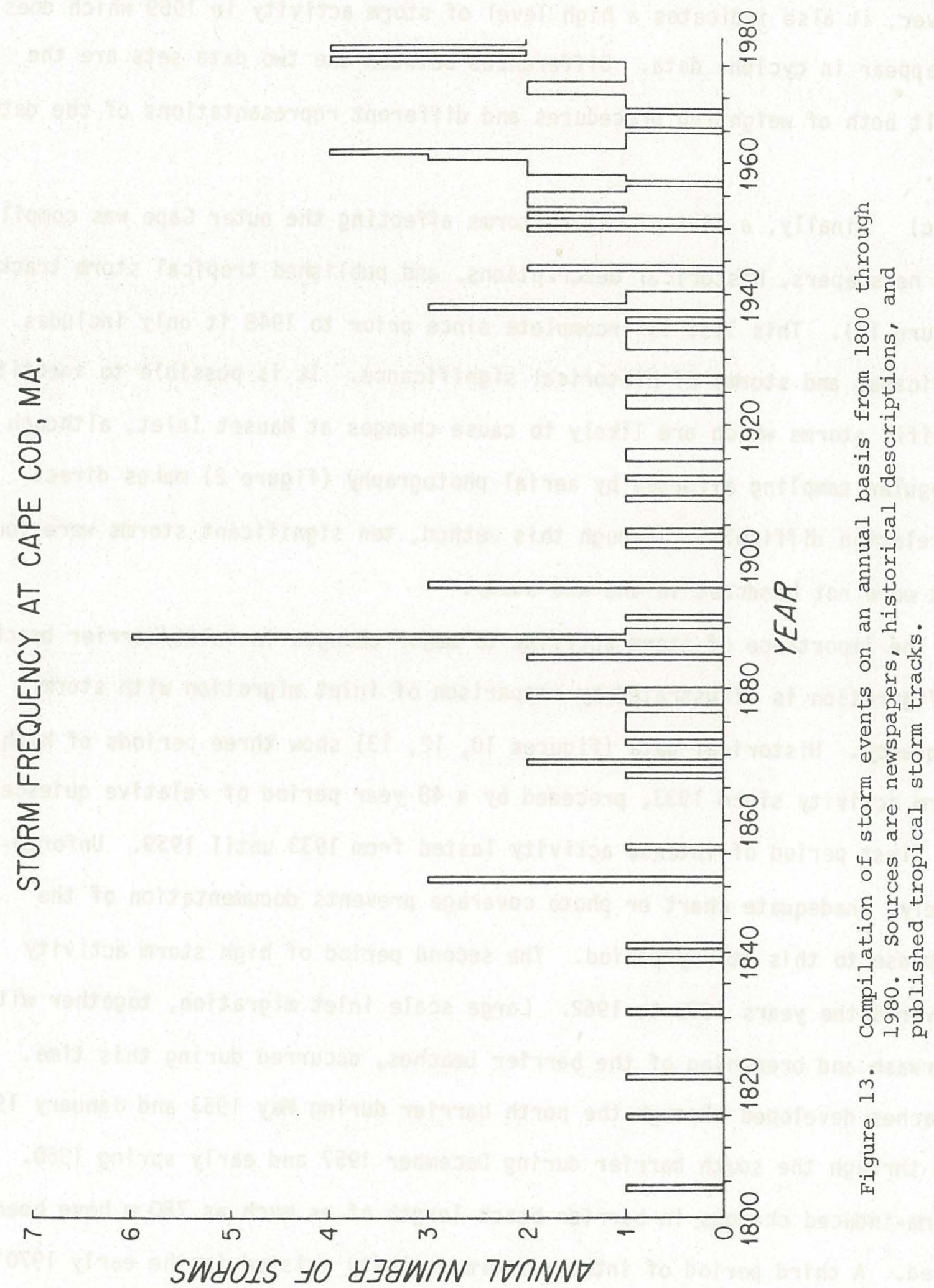


A question of central importance to tidal inlet stability is the means by which longshore sediment transport bypasses the inlet. The volume rate of longshore transport and the tidal prism are two primary indicators of inlet stability (e.g., Brunn and Gerritsen, 1959; Brunn, 1978). Large net 1ongshore transport rates, estimated to be about $250,000 \mathrm{~m}^{3} / \mathrm{yr}$ to the south (U.S. Army Corps of Engineers, 1969), occur in this area. Consequently, shallow overwashes typically are filled quickly, and the tidal prism seems capable of supporting only a single stable inlet. The relative proportions of sediment trapped in the inlet/estuary and bypassed to the south are not known. Two mechanisms for sediment bypassing at inlets have been identified (Brunn, 1978):

a. Bar Bypassing - Sand moves alongshore on the ebb tide delta, from the updrift barrier to the downdrift barrier, driven by a combination of wave and current action.

b. Tidal Bypassing - Sand enters the estuary on the flood tide and exits on the ebb, with a net downdrift bias. Both mechanisms invoke some unknown mechanism for sediment to escape the refractive influence of the ebb tide delta.

Bar bypassing has been documented several times at Nauset Inlet, increasing the length of the southern (downdrift) barrier. Three series of photographs in the mid-1950's demonstrate the existence of a bar bypassing mechanism at Nauset. The photographs show the motion of distal ebb delta bars around the perimeter of the delta and in two cases, attachment of a bar to the south spit.

The first series consists of four photographs taken during summer 1955 on May 2, June 15, Ju7y 14 and August 20 (figure 14). The motion of two bars on the ebb delta was measured. One bar was north of the main inlet channel and the other was south of the channel. The northern bar moved $150 \mathrm{~m}$ southward and 

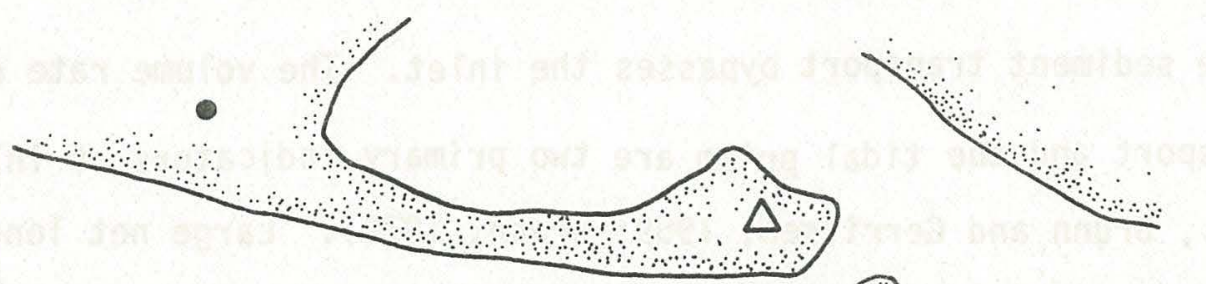

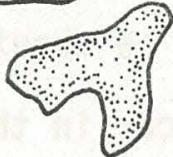

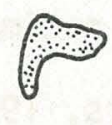

2 MAY 1955
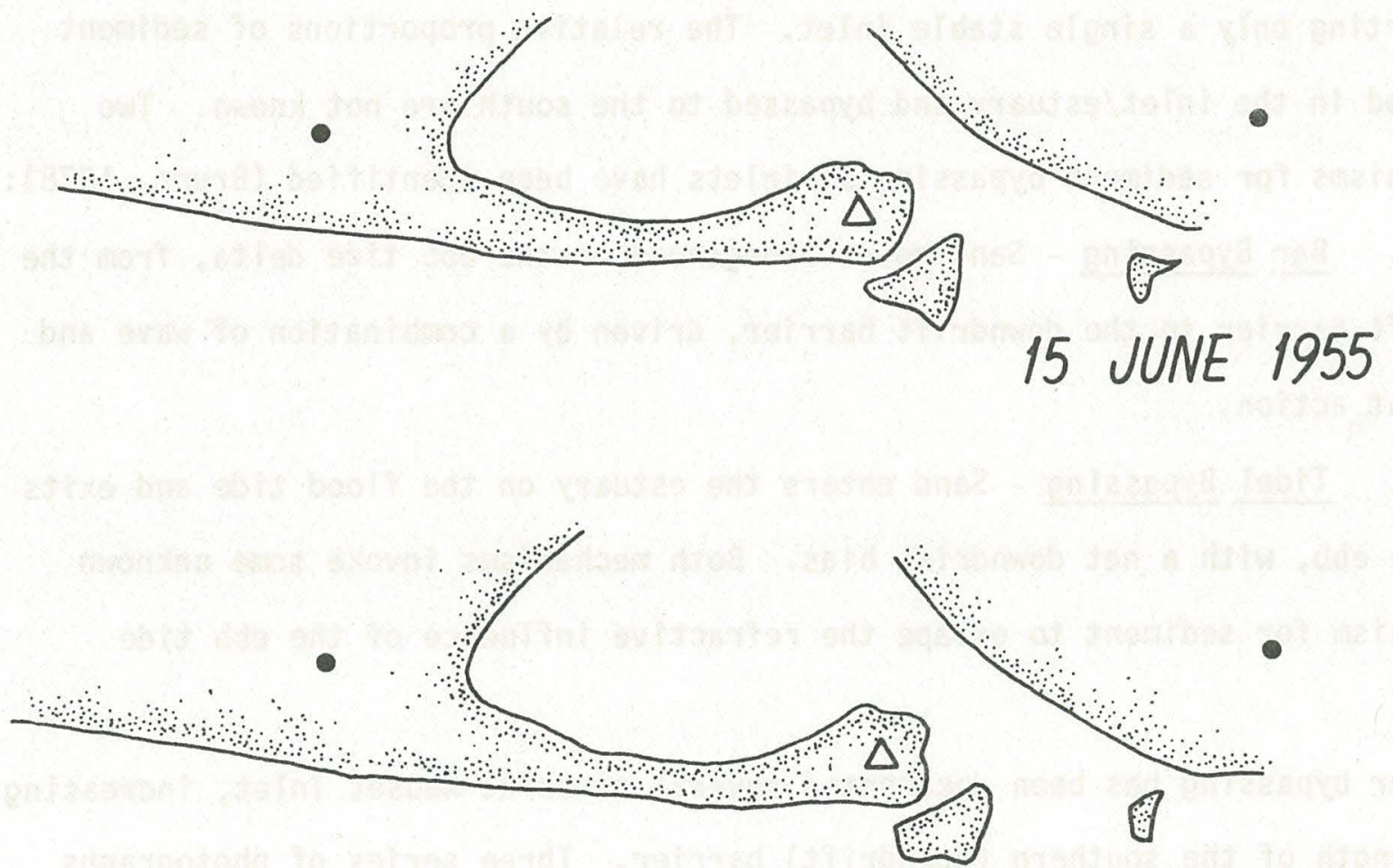

14 JULY 1955

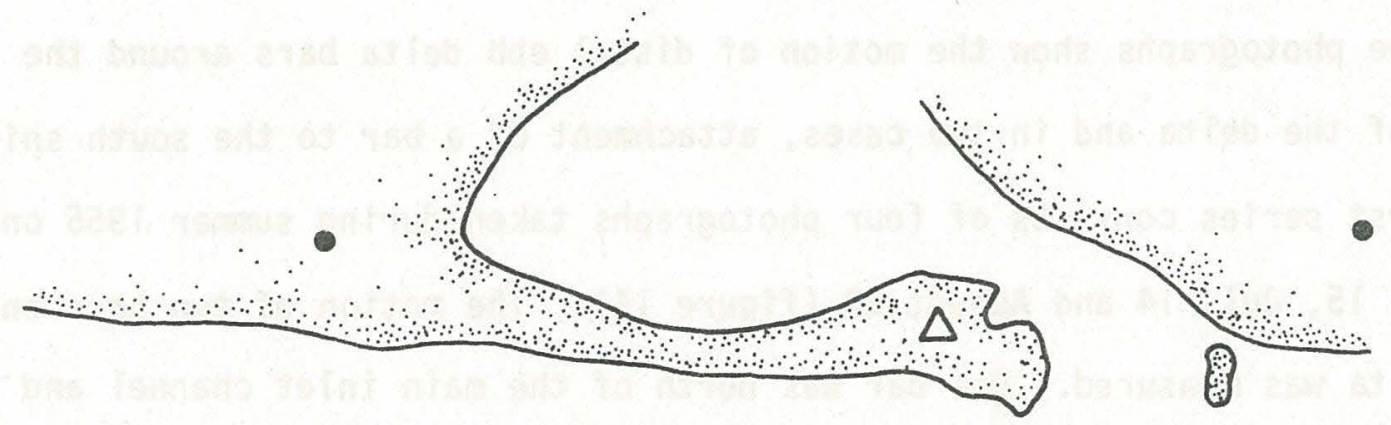

20 AUGUST 1955

Figure 14. Four month bar-bypassing events observed at Nauset Inlet, Cape Cod, Massachusetts. Ebb tide distal bar migrated 300 meters shoreward, attaching itself to and lengthening the downdrift barrier spit. 
$380 \mathrm{~m}$ westward between May 25 and August 20, however, it did not cross the inlet channel axis. The southern bar displayed no net alongshore motion, moving first south and then north. It did migrate $270 \mathrm{~m}$ to the west over the summer and welded to the tip of the south spit by August 20 .

The second series includes photographs taken February 9, February 21 and March 9, 1956. Additional observations were made on May 21 and on September 14, 1956. In this sequence, four bars were located on the ebb delta south of the inlet channel. One of the bars welded to the south spit between February 9 and 21. The other three migrated southward from $0 \mathrm{~m}$ to $100 \mathrm{~m}$ and westward from $40 \mathrm{~m}$ to $100 \mathrm{~m}$. The bars followed a path along the edge of the ebb delta and, as they neared the tip of the south spit, elongated to the east.

The third series of photographs in which bar migration was measured dates from the winter of 1957-1958. Positions of three bars were measured on October 21, 1957, December, 19, 1957 and March 13, 1958. The three bars moved between 0 and $80 \mathrm{~m}$ southward and between 110 and $240 \mathrm{~m}$ westward during this period.

\section{DISCUSSION}

The historical study has identified the following important features of Nauset Inlet's migration patterns: The apparent stability of the southernmost inlet entrance, the role of storms in initiating major changes in the inlet/ barrier beach system, and the recent tendency for the inlet to move in a direction opposite the predominant longshore drift. Migration of the inlet with accompanying changes in the barrier beaches takes place on essentially two different time scales. Major relocations of the inlet, involving longshore movements of hundreds of meters in several days, occur episodically during large storms. These dramatic changes have a recurrence interval of 
about one every ten years. The other important time scale is the recent steady migration of the inlet in a general northward direction. The combined effects of wave activity, tidal flows and longshore sand transport cause this movement. The magnitude is on the order of $100 \mathrm{~m} / \mathrm{yr}$. Northward migration of the inlet is accompanied by extension of the southern barrier and in some instances (e.g., 1973-1982) by shortening of the northern barrier.

The general stability of a southern inlet location at Nauset is not surprising. Most of the tidal prism passes through the southernmost channels of the marsh, therefore a southern inlet provides the most direct link to the ocean. The dominance of friction in Nauset's shallow inlet/estuary system (Aubrey and Speer, 1981 and 1982) makes a southern inlet location energetically favorable. The southernmost location has important effects on barrier beach configuration. In general, the northern barrier is not strongly eroded by tidal flows when the inlet is in this location as compared to a more northerly one (reasons for this are presented in the next section). Occasionally, a short, slowly growing southern spit can develop without catastrophic storm influence. Large scale growth of a south barrier is dependent on storm activity and breaching of the northern barrier. MODEL FOR LONGSHORE INLET MIGRATION

During the past 30 years, three distinct episodes of northward inlet growth have been ooserved: mid 1950's, late 1960's to early 1970's, and 1973-1982. The first two involved extension of the inlet channel to the north from a southern location, stability of the north barrier, and northward growth of the south barrier. A pattern of overlapping spits resulted in both cases. The most recent phase of inlet migration is qualitatively different from the 
previous two. The inlet channel has migrated to the north instead of simply elongating and the north barrier has been substantialiy eroded while the south barrier has extended north.

Inlets generally migrate in the direction of net longshore transport if they move at 211 (Brunn, 1978). Three different mechanisms (figure 15) are proposed to explain the unusual northward movement of Nauset Inlet, opposite the longshore transport direction: growth of the downdrift spit through bar bypassing of longshore sand transport, storm induced shifts of the inlet location; steady northward migration characterized by "flow around a bend" during etb tides. Each period of inlet migration is characterized by one or more of these processes.

The 1950's pattern of barrier overlap was initiated by breaching of the northern barrier during a storm. The barrier remnant south of the breach attached to Nauset Heights to form a relatively long southern spit. The base of the inlet channel retained its southern location and extended through the breach. Subsequently, the northern barrier lengthened by attachment to a marshy island in the bay. The south spit elongated by means of bar bypassing, resulting in the pattern of overlapping spits. As the south spit grew to the north, the inlet channel lengthened. The north spit remained relatively stable after attachment to the bay island.

The barriur overlap pattern of the late 1960's to early 1970's was initiated when the inlet was at its southernmost location. With the inlet at this position, the estuary channels empty directly into the ocean. No tendency exists for ebb flows to preferentially erode the north barrier. Tidal flows are strong enough, however, to prevent material transported past the north spit from filling in the inlet channel. Bar bypassing of littoral drift leads to 


\section{ACCRETION OF EBB DELTA BARS}
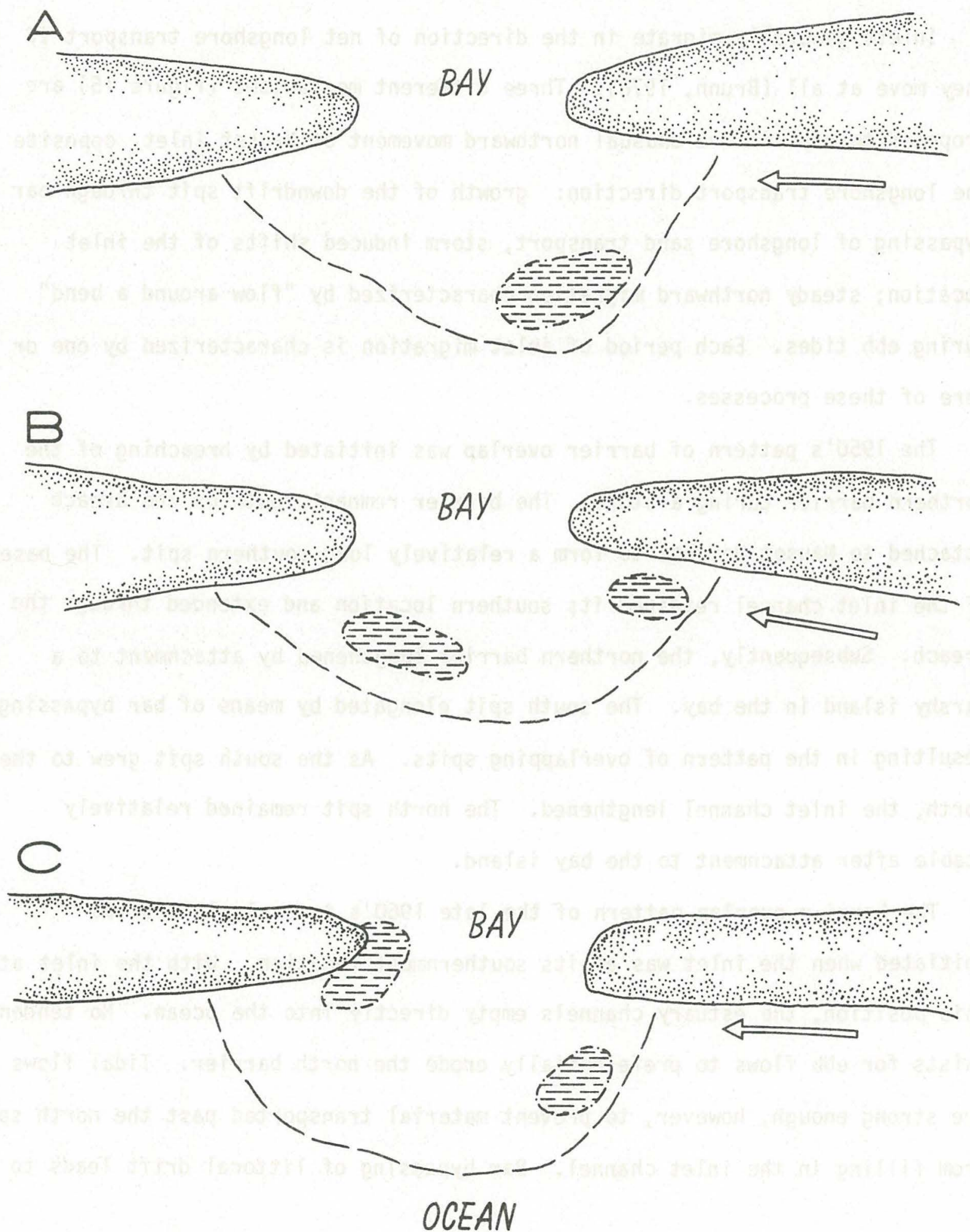

\section{$\lessdot \quad$ LONGSHORE SAND TRANSPORT}

Figure 15. Three modes of updrift inlet migration responding to different combinations of waves, tides and storms. All three modes have been observed at Nauset Inlet, Cape Cod, Massachusetts. 


\section{STORM-INDUCED SHIFTS}

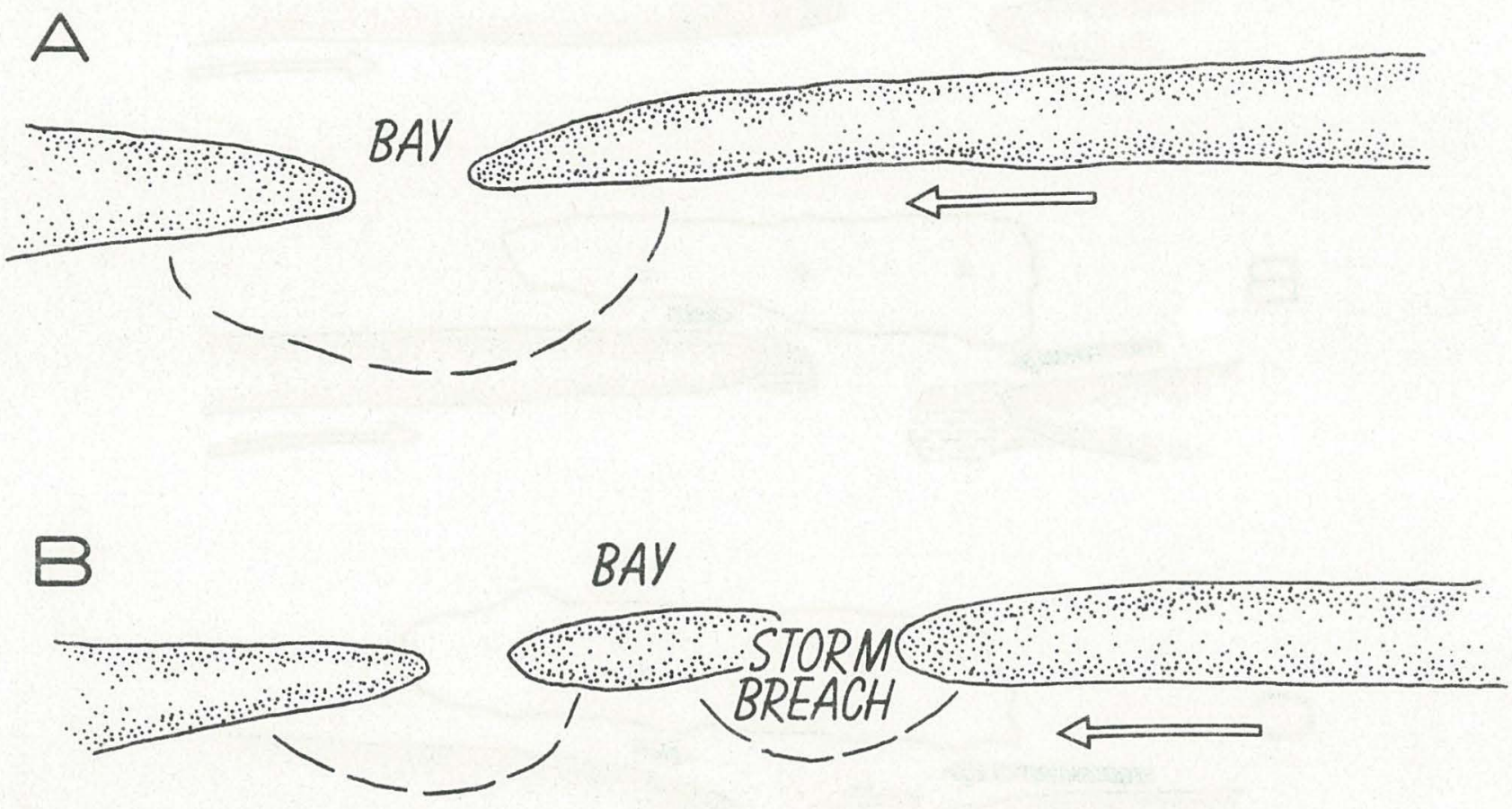

c

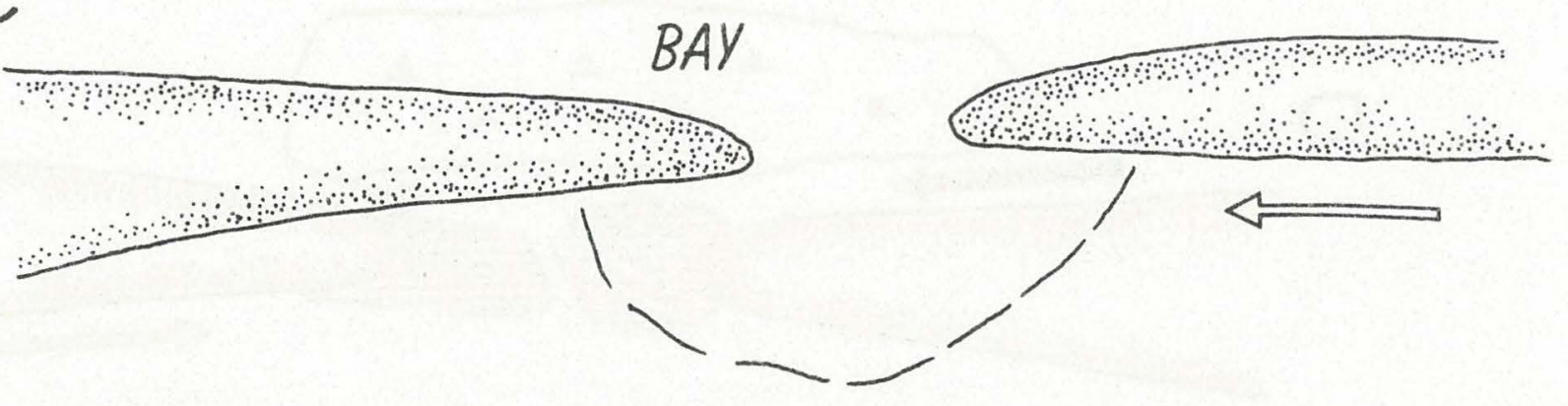

OCEAN

$\nLeftarrow$ LONGSHORE SAND TRANSPORT 

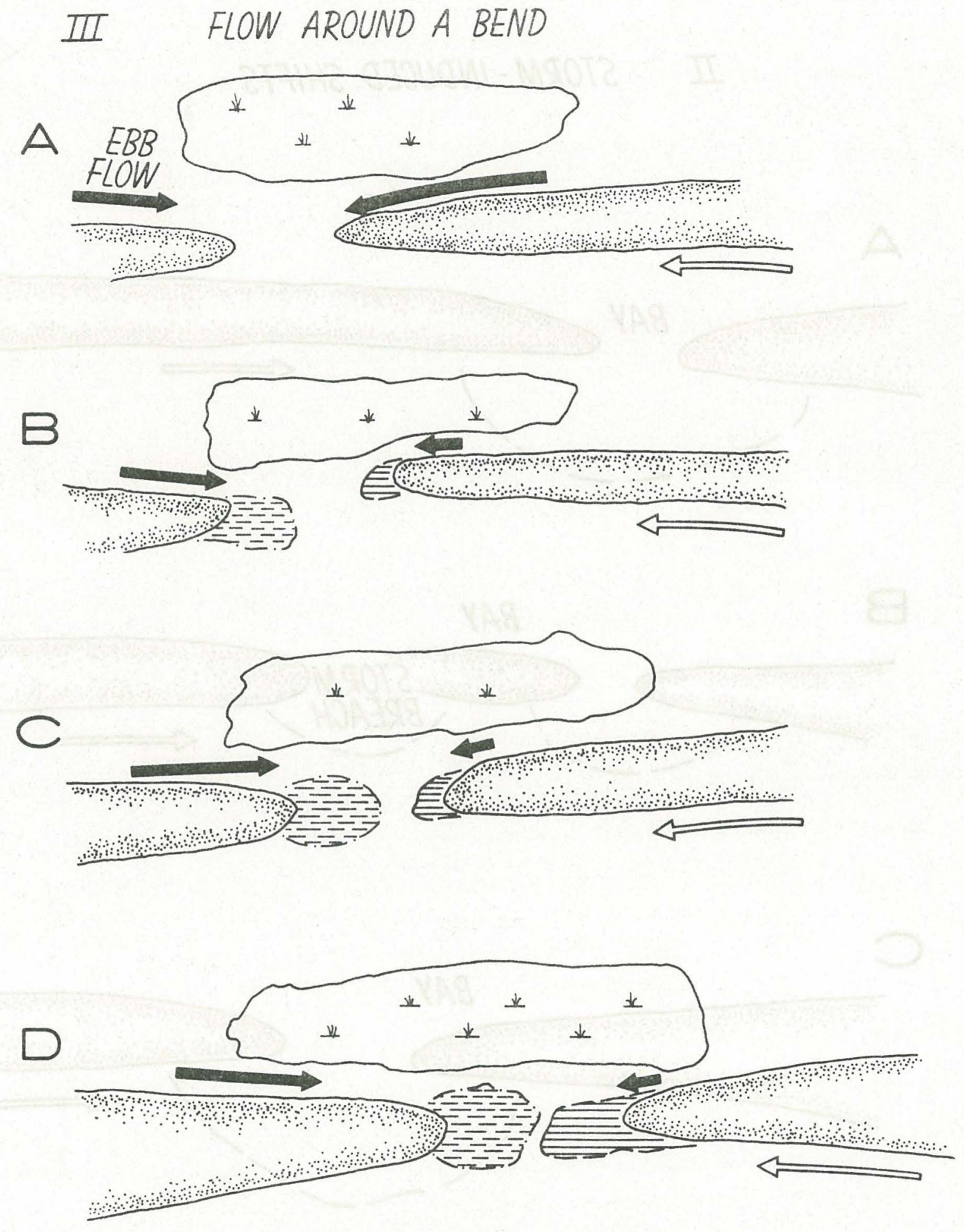

OCEAN

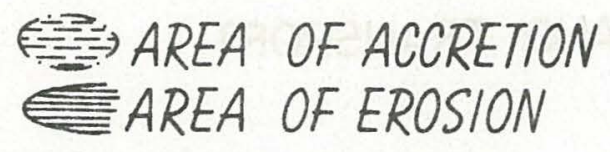

$\hookleftarrow$ LONGSHORE SAND TRANSPORT 
the development of a south spit. If storms do not halt this growth, the south spit can extend to the north and overlap the north spit, as occurred during this period.

The storm which breached the north spit in 1972 caused a new migration pattern to develop. The main inlet channel stabilized further north than it had previously been located. The dominant ebb tidal flow was constrained to flow north, and then east through the inlet channel. An analogy is drawn to "flow around a bend" in a river (Aubrey, in prep.). Experiment and theory have shown that in "flow around a bend", maximum flows and bottom stress are found on the outside of the bend (figure 15). Also, the surface of the water is superelevated on the outside of the bend. In a simple case, the superelevation produces a barotropic pressure gradient which drives a secondary flow towards the inner bank of the bend. This flow pattern resuits in erosion on the outer bank and deposition of a bar on the inner bank leading to migration of the river meanders. We are likely observing an analogous process at Nauset as a result of the storm-induced change in inlet location. The north wall of the inlet channel is presently eroding and a large sand deposit is forming on the south bank of the channel. Bar bypassing of longshore transport continues to add sand to the south spit. The emergent pattern is northward migration of the inlet with accompanying barrier beach changes, driven largely by unequal tidal discharge through southern and northern estuarine channels. The dominance of water exchange through the south channel imparts a strong directional bias leading to erosion of the north barrier, and deposition along the southern. 
This "flow around a bend" has been operating for approximately ten years, leading to nearly $1 \mathrm{~km}$ of northward inlet movement. Northward migration will probably continue until either the inlet encounters an erosion resistant substrate or a major storm changes the inlet location. In the case of Nauset, the former is unlikely (see Aubrey et al., 1982a) since inlet tidal flows are currently eroding relatively resistant peat deposits underneath the sandy barrier spits. Nothing more erosion-resistant is likely to be encountered under the north spit. The storm-induced inlet relocation is a strong possibility. The long, frictionally dominated channels carrying the tidal prism at present would probably be abandoned if a more southerly breach were created by a storm. In that case, the large longshore transport could quickly close off the present inlet. A more northerly inlet created by storm overwash is not likely to persist (as the February 1978 blizzard demonstrated) because the northern tidal prism is too small. An additional factor increasing the Tikelihood of breaching near Nauset Harbor is the narrow width of the barrier at this point. This narrowing is caused by erosion on the bay side of the barrier during ebb tide, as the easterly-flowing tide is redirected northwards towards the present inlet (resulting in another complex, more non-uniform flow pattern).

ONSHORE MIGRATION AND FATE OF THE ESTUARY

The long-term fate of this estuary is affected by two dominant trends: inlet migration (which contributes sediment to the estuary via flood tide delta growth) and onshore spit migration. Net onshore migration of the Nauset barrier beach is apparent in spite of large, higher frequency fluctuations. The steady shoreward migration is a result of sea level rise (a relatively 
minor factor) combined with overwash and inlet processes (barrier roll-over). Higher frequency oscillations superimposed on this steady retreat result from inlet migration episodes, seasonal beach changes, bar bypassing events, and Targe, nearshore bedform generation (Aubrey, 1980). The effect of the onshore migration is a reduction in tidal prism (specifically by reduction of the area of the back bay). Tidal prism is also reduced by deposition of sand as a flood tide delta, an important factor since 1972, as the inlet has steadily migrated northwards approximately $1 \mathrm{~km}$. Vestiges of the former flood tidal deltas are visible on recent aerial photographs of the area. As a result of overwash and bay infilling, the stable inlet configuration will become narrower and shallower with time (reduced equilibrium cross-sectional area).

\section{SUMMARY}

Three distinct patterns of natural inlet migration have been identified from historical data (figure 15), and their underlying causes hypothesized. These mechanisms explain the rare case where an inlet migrates in a direction opposite the dominant longshore sand transport, such as at Nauset Inlet. Large variability in barrier spit length across a baymouth can also be a reflection of these mechanisms. This rapid, spatially variable, inlet migration contributes to infilling of some inlet/estuary complexes on a geological time scale, as the continually enlarging flood tide delta evolves at each inlet location. The result is an accelerated shrinkage of some estuaries, with consequent reduction in inlet channel depth and width (the decreased channel area responding to a reduced tidal prism). Whether or not this flood tide delta growth significantly alters the fate of the estuary depends on the hydraulic characteristics of the inlet and estuary (flood tide delta growth is a function of flood/ebb flow dominance). 
The three distinct patterns of inlet migration are (fig. 15):

1) Growth of the downdrift spit by addition of sediment from ebb tide delta distal bars: some of these distal bars weld onto the downdrift spit without escaping the inlet environment. The time scale of these growth episodes is months, with an associated spit growth on a scale of $100 \mathrm{~m}$. The spit growth is relatively slow compared to the other two growth mechanisms.

2) Storm-induced shifts in inlet position associated with superelevated water levels: these changes are rare but significant, with time scales of tens of years and spatial scales of hundreds of meters. Storm breaches "ill remain stable and replace previous inlets if they are hydraulically more efficient than alternative breaches. These major inlet relocations have played an important role at Nauset Inlet, by shifting the inlet position to the north lagainst the sense of net littoral drift) and allowing the flow characteristics to set up a stable, steady northward inlet migration independent of storm influences.

Storm effects in the future are expected to influence the Nauset barriers significantly, and shift the inlet to the south. Since the southernmost limit of the estuary/inlet system has historically been the preferred position (because it is the most efficient location for tidal exchanges between the ocean and bay), a breach at this narrow part of the barrier will likely become the preferred inlet position. At present, a stable dune-line is inhibiting storm overwash and breaching at this location.

3) Steady northward migration characterized by flow around a bend (erosion on outside of bend, accretion on inside of bend) during ebb tides: this migration has occurred since 1972 when a storm breach rapidly shifted the inlet location, setting up a long, confined southern barrier-parallel channel through which most tidal exchange takes place. Ebb flow through this 
barrier-paraliel channel must make a sharp bend through the inlet to exit into the ocean. This bend creates a distinctive three-dimensional flow pattern similar to river bend flows, eroding the north spit and accreting to the south. The result is a steady northward migration which will cease when a storm opens a breach further south of the present inlet; this new breach will Tikely become the preferred inlet position.

\section{ACKNOWLEDGEMENTS}

This work was supported by NOAA, Office of Sea Grant under Grant No. NA80AA-D-00077 (R/B-21) and by the U.S. Army Research Office, under Grant DAAG2981-K-0004. Personnel from the Woods Hole Oceanographic Institution Archives, the U.S. National Archives, and the U.S. Library of Congress, were particularly helpful in making available data for our study. Final drafting of all figures was performed by W.H.O.I. Graphic Services personnel, particularly Stefan Masse and Phyl1is Hartley. The manuscript was typed by Pamela Barrows. 
References

Aubrey, D.G., 1980. Our dynamic coastlines. Oceanus, v. 23, no. 4, p. 4-13. Aubrey, D.G. and P.E. Speer, 1981. Tidal behavior through a tidal inlet.

[ABS.] Spring Meeting, A.G.U., Baltimore, MD.

Aubrey, D.G., D.C. Twichell and S.L. Pfirman, 1982. Holocene sedimentation in the shallow nearshore zone off Nauset Inlet, Cape Cod, Massachusetts, Marine Geology, v. 47, p. 243-259.

Aubrey, D.G. and P.E. Speer, 1982. Propagation of tidal disturbances through a shallow estuarine embayment; [ABS.] AGU/ASLO meeting, San Antrnio, TX. Aubrey D.G., P.E. Speer and E. Ruder, submitted. Updrift migration of tidal inlets: a natural response to wave, tide, and storm forcing. Aubrey, D.G., in preparation. Flow around a bend: a mechanism for tidal inlet migration.

Bruun, P., 1978, Stability of Tidal Inlets. Elsevier, New York, 506 pp. Bruun, P. and F. Gerritsen, 1960, Stability of Coastal Inlets. Amsterdam, North Holland Pub. Co., 124 pp.

Emery, K.0., 1980. Relative sea levels from tide gage records. Proc. of the National Academy of Sciences, v. 77, p. 6968-6972.

Emery, K.0. and E. Uchupi, 1972. Western North Atlantic Ocean: topography, rocks, structure, water, 1ife and sediments, AAPG, Memoir 17, 532 pp. Hayden, B.P. and W. Smith, 1982. Season-to-season cyclone frequency prediction. Monthly Weather Review, v. 110, p. 239-253. Leatherman, S.P. (ed.), 1979. Environmental Geologic Guide to Cape Cod National Seashore, S.E.P.M. Field Guide Book, 249 pp. Leatherman, S.P., A.J. Williams, and J.S. Fisher, 1977, Overwash sedimentation associated with a large scale northeaster. Marine Geology, v. 24, p. $109-121$. 
Miller, M.C. and D.G. Aubrey, 1982. Beach changes at Cape Cod, MA., U.S. Army C.E.R.C. Misc. Report, in press.

Redfield, A.C., and M. Rubin, 1962, The age of salt marsh peat and its relation to recent changes in sea level at Barnstable, MA. Proc. Nat. Acad. of Sciences, v. 48, p. 1728-1735.

U.S. Army Corps of Engineers, 1969. Nauset Harbor, Orleans and Eastham, Massachusetts, Survey Report, Department of the Army, New England Division, Corps of Engineers, Waltham, Mass., $13 \mathrm{pp} .+$ appendices. U.S. Army Corps of Engineers, 1979, Cape Cod easterly shore beach erosion study, v. 1, 11, 111. New England Division, Corps of Engineers, Waltham, MA.

Wright, A.E., 1978. Statistical verification of geomorphic changes on a breached spit. Unpublished thesis, Boston College, Dept. of Geology and Geophysics, 232 pp.

Wright, A.E. and B.M. Brenninkmeyer, 1979. Sedimentation patterns at Nauset Inlet, Cape Cod, Massachusetts. In Leatherman, S.P. (ed.), Environmental Geologic Guide to Cape Cod National Seashore, S.E.P.M. Guide Book, p. 119-140.

Zaremba, , and S.P. Leatherman, 1979, Overwash processes and barrier dynamics: Nauset Spit, Cape Cod, MA., U. MA-N.P.S.-C.R.U. Progress Report, 245 p.

Zeigler, J.M., 1954. Beach Studies in the Cape Cod area conducted during the period January 1, 1954 - June 30, 1954. Woods Hole Oceanographic Institution, unpublished manuscript, reference number 54-59, 14 pp. Zeigler, J.M., 1960, Cape Studies, Cape Cod, Aug. 1953 - Apri1 1960. Woods Hole Oceanographic Institution, unpublished report No. 60-20, 32 pp. 
APPENDIX 1

HISTORICAL CHARTS (1670 - 1978)

$-47-$ 


\begin{tabular}{|c|c|c|c|c|}
\hline Date & Scale $e^{1 /}$ & Source & Depository & Title (or Description) \\
\hline 1670 & $(1: 24,000)$ & Anon. & WHOI $156 \mathrm{M}$ & $\begin{array}{l}\text { Chart of Eastham and } \\
\text { Orleans. }\end{array}$ \\
\hline 1680 & $(1: 328,000)$ & Anon. & WHOI $154 \mathrm{M}$ & $\begin{array}{l}\text { Chart of the coast of } \\
\text { Maine, New Hampshire, } \\
\text { Massachusetts and New } \\
\text { Plymouth. }\end{array}$ \\
\hline 1694 & $(1: 398,000)$ & Southhack & $\begin{array}{l}\text { NA P.G-23 } \\
844: 1734\end{array}$ & $\begin{array}{l}\text { Chart of the coast of } \\
\text { Massachusetts from survey } \\
\text { made by Capt. Cyprian } \\
\text { Southack. }\end{array}$ \\
\hline 1702 & ---- & ---- & NPS & \\
\hline 1717 & ----- & $-\ldots$ & NPS & \\
\hline 1738 & $(1: 182,000)$ & Anon. & WHOI $152 \mathrm{M}$ & $\begin{array}{l}\text { Colony of Plymouth... (Map } \\
\text { of Cape Cod and S.E. } \\
\text { Massachusetts). }\end{array}$ \\
\hline 1779 & $(1: 135,000)$ & Desbarres & LC & (Map of Cape Cod) \\
\hline $177 ?$ & $(1: 450,000)$ & Anon. & LC & $\begin{array}{l}\text { A plan of the Sea Coast } \\
\text { from Boston Bay to the } \\
\text { Light House near Rhode } \\
\text { Island. }\end{array}$ \\
\hline 1781 & $(1: 137,000)$ & $\begin{array}{l}\text { Atlantic } \\
\text { Neptune }\end{array}$ & WHOI $162 \mathrm{M}$ & (Map of Cape Cod) \\
\hline 1788 & -..-- & Green & LC & (Map of Cape Cod) \\
\hline $1788-9$ & $-\cdots$ & Carlton & LC & (Map of Cape Cod) \\
\hline 1794 & $-\ldots-$ & Stockdale & LC & (Map of Cape Cod) \\
\hline 1795 & $(1: 1,200,000)$ & Lewis & WHOI $177 \mathrm{M}$ & (Map of Cape Cod) \\
\hline 1795 & ----- & ---- & NPS & \\
\hline 1796 & $(1: 1,500,000)$ & $\begin{array}{l}\text { Morse/ } \\
\text { Jedidiot } \\
\text { (Denison) }\end{array}$ & LC & Map of Massachusetts \\
\hline
\end{tabular}




\section{HISTORICAL CHARTS (NAUSET)}

\begin{tabular}{|c|c|c|c|c|}
\hline Date & Scale & Source & Depository & Title (or Description) \\
\hline 1798 & $-\cdots--$ & Sotzman & WHOI & \\
\hline 1798 & $(1: 125,000)$ & Anon. & WHOI $160 \mathrm{M}$ & $\begin{array}{l}\text { (Map of Cape Cod; Concord } \\
\text { Public Library). }\end{array}$ \\
\hline 1798 & $(1: 160,000)$ & Anon. & WHOI $249 \mathrm{M}$ & $\begin{array}{l}\text { (Map of Cape Cod; Anerican } \\
\text { Antiquities Society). }\end{array}$ \\
\hline 1803 & $(1: 140,000)$ & Anon. & WHOI $114 \mathrm{M}$ & (Map of Cape Cod). \\
\hline 1810 & $(1: 250,000)$ & Levis & LC & $\begin{array}{l}\text { (Geographic and political } \\
\text { map of Mass.). }\end{array}$ \\
\hline 1822 & $1: 680,000$ & Carey and Lea & LC & The State of Massachusetts. \\
\hline 1822 & $--\cdots-$ & Carleton & NA U.S. 97 & Map of Massachusetts. \\
\hline 1822 & ----- & Gillet & LC & (Map of Cape Cod). \\
\hline 1824 & $-\cdots$ & Finely & LC & (Map of Cape Cod by Levis). \\
\hline 1826 & $(7 ; 690,000)$ & $\begin{array}{l}\text { Lucas/ } \\
\text { Fielding }\end{array}$ & LC & $\begin{array}{l}\text { Geographical, Historical } \\
\text { and Statistical Map of } \\
\text { Massachusetts. No. } 12 \text {. }\end{array}$ \\
\hline 1827 & $-\cdots-$ & Morse & LC & (Map of Cape Cod). \\
\hline 1827 & $-\ldots--$ & Carey/Lea & LC & (Map of Cape Cod by Levis). \\
\hline $183 ?$ & ---- & Finley & LC & (Map of Cape Cod by Levis). \\
\hline 1831 & $-\ldots-$. & $-\ldots-$. & NPS & (CENSUS Map). \\
\hline 1832 & $(?: 160,000)$ & Anon. & WHOI 101 & (Map of Cape Cod). \\
\hline 1832 & $-m n---$ & Mitchell & LC & (Map of Cape Cod by Lewis). \\
\hline 1832 & $---\cdots$ & $\begin{array}{l}\text { Hinton, } \\
\text { Sinpkin, \& } \\
\text { Marshalt }\end{array}$ & LC & (Map of Massachusetts). \\
\hline 1832 & $-\cdots$ & Hitchcock & WHOI & \\
\hline 1833 & $-\cdots--$ & Sumner & LC & (Map of Cape Cod by Levis). \\
\hline
\end{tabular}




\begin{tabular}{|c|c|c|c|c|}
\hline Date & Scale ${ }^{1 /}$ & Source & Depository & Title (or Description) \\
\hline 1833 & $1: 830,000$ & Tanner & LC & $\begin{array}{l}\text { Massachusetts and Rhode } \\
\text { Island. }\end{array}$ \\
\hline 1836 & $1: 400,000$ & Otis/Broader & LC & New Map of Massachusetts. \\
\hline 1836 & $1: 490,000$ & Wilcox & LC & $\begin{array}{l}\text { Map of Massachusetts, } \\
\text { Rhode I sland and } \\
\text { Connecticut. }\end{array}$ \\
\hline 1836 & ---- & Packard/Brown & LC & (Map of Cape Cod by Lewis). \\
\hline 1837 & $-\cdots--$ & Mitchell & LC & (Map of Cape Cod by Lewis). \\
\hline 1838 & $-\cdots--$ & & NPS & (Town planning map). \\
\hline 1838 & $\cdots-$ & Bradford & LC & \\
\hline 1838 & $-\cdots--$ & $\begin{array}{l}\text { Brovm } \\
\text { Parsons }\end{array}$ & LC & \\
\hline 1840 & $-\cdots--$ & Darr/Howland & LC & \\
\hline 1841 & $(1: 830,000)$ & Tanner & LC & $\begin{array}{l}\text { Massachusetts and Rhode } \\
\text { Island. }\end{array}$ \\
\hline 1841 & $\cdots--$ & Phelps/Ensign & LC & $\begin{array}{l}\text { Map of Massachusetts, } \\
\text { Rhode Island and } \\
\text { Connecticut. }\end{array}$ \\
\hline 1844 & $1: 316,800$ & Hitchcock & $\begin{array}{l}\text { NA RG-23 } \\
\text { L\&A } 844 \\
1844-3(2)\end{array}$ & $\begin{array}{l}\text { Geological Map of } \\
\text { Massachusetts. }\end{array}$ \\
\hline 1844 & $1: 158,400$ & Borden & $\begin{array}{l}\text { NA RG-23 } \\
\text { L\&A 844: } \\
1844-2(1)\end{array}$ & (Map of Massachusetts). \\
\hline 1844 & $-\cdots--$ & Smith & LC & (Map of Massachusetts). \\
\hline 1845 & $1: 80,000$ & USC\&GS & & $\begin{array}{l}\text { Chart 110-111, Map of Cape } \\
\text { Cod. }\end{array}$ \\
\hline 1852 & $-\cdots--$ & Anon. & ----- & $\begin{array}{l}\text { (Map of Cape Cod in } \\
\text { Thoreau Gasetteer). }\end{array}$ \\
\hline
\end{tabular}


HISTORICAL CHARTS (NAUSET)

\begin{tabular}{|c|c|c|c|c|}
\hline Date & Scale & Source & Depository & Title (or Description) \\
\hline 1856 & $-\ldots-\ldots$ & Anon. & WHOI 239-M & Nauset Harbor. \\
\hline 1857 & $\ldots-\cdots$ & Bache & NA $R G-77$ & Nauset Ilarbor. \\
\hline 1858 & $1: 81,000$ & Walling & LC & (Map of Massachusetts). \\
\hline 1871 & $-\cdots--$ & Anon. & LC & (Map of Massachusetts). \\
\hline 1871 & $--\cdots-$ & Anon. & WHOI $143 \mathrm{II}$ & \\
\hline 1872 & $1: 80,000$ & USC\&GS & WHOI $230 \mathrm{M}$ & $\begin{array}{l}\text { Chart 110, Map of Cape Cod } \\
\text { (Topo. 1848-68). }\end{array}$ \\
\hline 1874 & $1: 80,000$ & USC\&GS & $\therefore$ & Chart 111. \\
\hline 1877 & $1: 570,000$ & Gray & $\begin{array}{l}\text { NA } R G-77 \\
\text { US } 373-59\end{array}$ & $\begin{array}{l}\text { Massachusetts, Thode Island } \\
\text { and Connecticut. }\end{array}$ \\
\hline 1880 & $-\cdots-$ & Anon. & NPS & (Town of Orleans). \\
\hline 1880 & ---- & Anon. & NPS & Map No. 17. \\
\hline 1887 & $1: 10,000$ & Marindin & WHOI $2.20 \mathrm{M}$ & $\begin{array}{l}\text { Cross Sections off Nauset } \\
\text { beach. }\end{array}$ \\
\hline $\begin{array}{l}1848- \\
1888\end{array}$ & $1: 40,000$ & Marindin & LC & $\begin{array}{l}\text { Physical Survey Cape Cod, } \\
\text { Mass. }\end{array}$ \\
\hline 1892 & $1: 130,000$ & Walker & LC & Cape Cod and Vicinity. \\
\hline 1892 & $1: 80,000$ & USC\&GS & NA & Cape Cod Bay. \\
\hline 1893 & $-\cdots-$ & Gannet (USGS) & NA & \\
\hline 1894 & 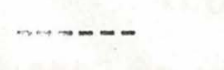 & Anon. & NPS & (USC\&GS). \\
\hline 1896 & $-\cdots$ & Eldridge & WHOI $159 \mathrm{M}$ & \\
\hline 1898 & $-\cdots-$ & & & \\
\hline 1900 & ----- & Anon. & NPS & (USC\&GS). \\
\hline 1901 & $\ldots \ldots$ & Anon. & NPS & (USC\&GS). \\
\hline
\end{tabular}




\begin{tabular}{|c|c|c|c|c|}
\hline Date & Scale & Source & Depository & Title (or Description) \\
\hline 1902 & $-\cdots$ & Walker & LC & $\begin{array}{l}\text { (Map of Cape Cod and } \\
\text { Vicinity). }\end{array}$ \\
\hline 1903 & $\ldots-\cdots$ & Anon. & NPS & \\
\hline 1905 & $-\ldots--$ & Walker & LC & $\begin{array}{l}\text { (Map of Cape Cod and } \\
\text { Vicinity). }\end{array}$ \\
\hline 1907 & $--\cdots$ & Walker & LC & $\begin{array}{l}\text { (Map of Cape Cod and } \\
\text { Vicinity). }\end{array}$ \\
\hline 1908 & $-\ldots$ & Walker & LC & $\begin{array}{l}\text { (Map of Cape Cod and } \\
\text { Vicinity). }\end{array}$ \\
\hline 1908 & $-\ldots$ & & NPS & \\
\hline 1909 & $-\cdots-$ & Walker & LC & $\begin{array}{l}\text { (Map of Cape Cod and } \\
\text { Vicinity). }\end{array}$ \\
\hline 1910 & $1: 80,000$ & USC\&GS & NA $R G-23$ & Cape Cod Bay, Chart 110. \\
\hline 1910 & $-\ldots--$ & Walker & LC & $\begin{array}{l}\text { (Map of Cape Cod and } \\
\text { Vicinity). }\end{array}$ \\
\hline 1911 & $-\ldots$ & Walker & LC & $\begin{array}{l}\text { (Map of Cape Cod and } \\
\text { Vicinity). }\end{array}$ \\
\hline 1915 & $1: 80,000$ & USC\&GS & NPS & $\begin{array}{l}\text { Chart } 111 \text {, (topography not } \\
\text { updated). }\end{array}$ \\
\hline 1915 & $1: 80,000$ & USC\&GS & NPS & $\begin{array}{l}\text { Chart } 1208 \text { (topography not } \\
\text { updated). }\end{array}$ \\
\hline 1915 & ---- & Walker & LC & $\begin{array}{l}\text { (Map of Cape Cod and } \\
\text { vicinity). }\end{array}$ \\
\hline 1916 & $-\ldots-$ & Woodworth & WHOI 198 H & (Geology of Cape Cod). \\
\hline 1917 & $1: 62,500$ & USGS & NA & $\begin{array}{l}\text { Massachusetts, Wellfleet, } \\
\text { Mass Quadrangle. }\end{array}$ \\
\hline 1920 & $-\ldots-$ & Anon & LC & $\begin{array}{l}\text { (Map of Postal routes on } \\
\text { Cape Cod). }\end{array}$ \\
\hline 1920 & $(1: 80,000)$ & $\begin{array}{l}\text { US Bureau } \\
\text { of Soils }\end{array}$ & LC & $\begin{array}{l}\text { Soils Map, Massachusetts, } \\
\text { Barnstable County Sheet. }\end{array}$ \\
\hline
\end{tabular}


HISTORICAL CHARTS (NAUSET)

\begin{tabular}{|c|c|c|c|c|}
\hline Date & Scale $1 /$ & Source & Depository & Title (or Description) \\
\hline 1922 & $\ldots$ & $\begin{array}{l}\text { Bureau of } \\
\text { Public Works }\end{array}$ & LC & (Map of Cape Cod). \\
\hline 1924 & $-\cdots-$ & Eldridge & WHOI $199 \mathrm{M}$ & (llap of Cape Cod). \\
\hline 1926 & $-\cdots-\cdots$ & Malanie & LC & $\begin{array}{l}\text { (Pictoral chart of Cape } \\
\text { Cod). }\end{array}$ \\
\hline 1926 & $1: 62,500$ & USGS & NA & $\begin{array}{l}\text { Chatham, Mass. Quadrangle } \\
\text { (not updated). }\end{array}$ \\
\hline 1930 & $-\cdots$ & $\cdots-\cdots$ & LC & (Pictoral map of Cape Cod). \\
\hline 1931 & $(1: 160,000)$ & Tripp & LC & $\begin{array}{l}\text { (I) lustrated map of Cape } \\
\text { Cod). }\end{array}$ \\
\hline 1932 & $-\cdots-\cdots$ & Goffney & LC & (Map of Cape Cod). \\
\hline 1933 & $-\cdots-$ & Cravford Press & LC & (Pictoral map of Cape Cod). \\
\hline 1934 & $-\cdots-\cdots$ & $\begin{array}{l}\text { Cape Cod } \\
\text { Chamber of } \\
\text { Commerce }\end{array}$ & LC & Tourist Map of Cape Cod. \\
\hline 1935 & $-\cdots--$ & $\begin{array}{l}\text { National Ocean } \\
\text { Survey, Co. }\end{array}$ & LC & $\begin{array}{l}\text { (Tourist map of Cape Cod } \\
\text { for Copley Plaza). }\end{array}$ \\
\hline 1936 & $\ldots-\cdots$ & Robbins Studio & LC & Wallet Map of Cape Cod. \\
\hline 1938 & (AER & AL PHOTO COVERAG & AE STARTS HERE & - See Appendix 2) \\
\hline 1938 & $\ldots-\cdots$ & USC\&GS & WHOI $200 \mathrm{~L}$ & \\
\hline 1939 & 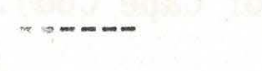 & Gulf $0 i l$ & LC & (Road Map of Cape Cod). \\
\hline 1941 & $-\cdots+--$ & Auto & LC & (Auto Map of Cape Cod). \\
\hline 1944 & $-\cdots-$ & USC\&GS \#50 & WHOI 247 M & $\begin{array}{l}\text { (Map of Cape Cod; based on } \\
\text { surveys up to 1941). }\end{array}$ \\
\hline 1946 & $1: 80,000$ & USC\&GS & WHOI & $\begin{array}{l}\text { Chart } 1208 \text { (Map of Cape } \\
\text { Cod dated 1942: updated } \\
1946) \text {. }\end{array}$ \\
\hline 1946 & $1: 24,000$ & USGS & WHOI $300 \mathrm{~L}$ & Orleans, Mass. Quadrangle. \\
\hline
\end{tabular}




\begin{tabular}{|c|c|c|c|c|}
\hline Date & Scale & Source & Depository & Title (or Description) \\
\hline 1947 & $\ldots-\ldots$ & Miller & LC & (Map of Cape Cod). \\
\hline 1952 & $1: 10,560$ & Shaw & WHOI & Eastham Marsh. \\
\hline 1953 & $1: 80,000$ & USC\&GS & WHOI & $\begin{array}{l}\text { Chart } 1208 \text { (Map of Cape } \\
\text { Cod dated 1942: updated in } \\
1953 \text { ). }\end{array}$ \\
\hline $\begin{array}{l}7954 \\
17 \text { May }\end{array}$ & $1: 2400$ & Zeigler & $\begin{array}{l}\text { WHOI ref. } \\
\# \text { 55-12 }\end{array}$ & $\begin{array}{l}\text { (Plane table survey of } \\
\text { Nauset Beach). }\end{array}$ \\
\hline $\begin{array}{l}1954 \\
25 \text { June }\end{array}$ & $7: 2400$ & Zeigler & $\begin{array}{l}\text { WHOI ref. } \\
\# 55-12\end{array}$ & $\begin{array}{l}\text { (Plane table survey of } \\
\text { Nauset Beach). }\end{array}$ \\
\hline $\begin{array}{l}1954 \\
12 \text { Ju7y }\end{array}$ & $1: 2400$ & Zeigler & $\begin{array}{l}\text { WHOI ref. } \\
\# 55-12\end{array}$ & $\begin{array}{l}\text { (Plane table survey of } \\
\text { Nauset Beach). }\end{array}$ \\
\hline $\begin{array}{l}1954 \\
23 \text { Aug } \\
1954 \\
2 \text { Sept }\end{array}$ & $1: 2400$ & $\begin{array}{l}\text { Zeigler } \\
\text { Zeigler }\end{array}$ & $\begin{array}{l}\text { WHOI ref. } \\
\# \text { 55-12 } \\
\text { WHOI ref. } \\
\# 55-12\end{array}$ & $\begin{array}{l}\text { (Plane table survey of } \\
\text { Nauset Beach). } \\
\text { (Plane table survey of } \\
\text { Nauset Beach). }\end{array}$ \\
\hline $\begin{array}{l}1954 \\
15 \text { Sept }\end{array}$ & $1: 2400$ & Zeigler & $\begin{array}{l}\text { WHOI ref. } \\
\text { \# 55-12 }\end{array}$ & $\begin{array}{l}\text { (Plane table survey of } \\
\text { Nauset Beach). }\end{array}$ \\
\hline $\begin{array}{l}1954 \\
14 \text { oct }\end{array}$ & $1: 2400$ & Zeigler & $\begin{array}{l}\text { WHOI ref. } \\
\# 55-12\end{array}$ & $\begin{array}{l}\text { (Plane table survey of } \\
\text { Nauset Beach). }\end{array}$ \\
\hline $\begin{array}{l}1954 \\
1 \mathrm{DeC}\end{array}$ & $1: 2400$ & Zeigler & $\begin{array}{l}\text { WHOI ref. } \\
\# 55-12\end{array}$ & $\begin{array}{l}\text { (Plane table survey of } \\
\text { Nauset Beach). }\end{array}$ \\
\hline 1956 & ---- & Map Corp. & LC & (Map of Cape Cod). \\
\hline 1959 & ---- & $\begin{array}{l}\text { Conmunity } \\
\text { Advertising }\end{array}$ & LC & (Map of Cape Cod). \\
\hline 1961 & $-\cdots-$ & USC\&GS & NPS & (Topography no updated). \\
\hline 1962 & $1: 24,000$ & USGS & WHOI $300 \mathrm{~L}$ & Orleans, Mass. Quadrangle. \\
\hline 1971 & $7: 80,000$ & USC\&GS & WHOI & Chart 1208. \\
\hline 1974 & $1: 24,000$ & USGS & WHOI & Orleans, Mass. Quadrangle. \\
\hline 1978 & $1: 80,000$ & NOAA & WHOI & Chart 13246 (1208). \\
\hline
\end{tabular}


ABBREVIATIONS:

LC: Library of Congress, Geography and Maps Room, Washington, D.C.

MA: Commonvealth of Massachusetts Archives. Boston, MA.

NA: National Archives, (RG = Records Group). Washington, D.C.

USC\&GS: U.S. Coast and Geodetic Survey (and NOS - National Ocean Survey), Rockville, MD.

USGS: United States Geological Survey, Sioux Falls, S.D.

WHOI: Woods Hole Oceanographic Institution, Woods Hole, MA.

NPS: National Park Service, Cape Cod National Seashore, Wellfieet, M. 
$-55 a-$ 
APPENDIX 2

HISTORICAL PHOTOGRAPHS (1938 - 1981)

$-56-$ 
APPENDIX 2

AERIAL PHOTOGRAPHS OF NAUSET INLET

Year Date Photographed Obtained Vertical/Frame \#('s) Scale By From oblique

\begin{tabular}{|c|c|c|c|c|c|}
\hline 193821 Nov. & & NARS & V & GSF 509,511 & $1: 23,158$ \\
\hline 195120 oct. & NOS & NOS/NOAA & V & J 5148-5154 & $1: 9498$ \\
\hline 19523 June & & VIMS (P.JB) & V & DPL $3 K \quad G \& 8$ & $1: 20,220$ \\
\hline 195310 May & NOS (USC\&GS) & NOS & V & $\begin{array}{l}\mathrm{J} 0782,0784, \\
0786\end{array}$ & $1: 9950$ \\
\hline 1953 Aug & & $\begin{array}{l}\text { JMZ-WHOI } \\
\text { Ref \#55-12 }\end{array}$ & 0 & & \\
\hline 1954 Summer & & $\begin{array}{l}\text { JMZ-WHOI } \\
\text { Ref \#55-12 }\end{array}$ & 0 & & \\
\hline 1954 Summer & & $\begin{array}{l}\text { JMZ-WHOI } \\
\text { Ref \#55-12 }\end{array}$ & V & & \\
\hline $195518 \mathrm{Jan}$. & Stetson & JMZ-WHOI & V & & \\
\hline 195515 Mar. & USC\&GS & NOS & V & W 5002, 5004 & $1: 24599$ \\
\hline 195511 Apri1 & Stetson & JMZ-WHOI & V & & \\
\hline 19552 May & Stetson & JMZ-WHOI & V & & $1: 10,395$ \\
\hline 195525 May' & Stetson & JMZ-WHOI & V & & $1: 10101$ \\
\hline 195515 June & Stetson & JMZ-WHOI & V & & $1: 13,122$ \\
\hline 195514 July & Stetson & JMZ-WHOI & V & & $1: 16,747$ \\
\hline 195520 Aug. & Stetson & JMZ-WHOI & V & & $1: 16,463$ \\
\hline 195525 oct. & Stetson & JMZ-WHOI & V & & $1: 15,746$ \\
\hline 195527 Nov. & Stetson & JMZ-WHOI & v & & \\
\hline $195624 \mathrm{Jan}$. & Stetson & JMZ-WHOI & V & & \\
\hline 19568 Feb. & Stetson & JMZ-WHOI & V & & \\
\hline 19569 Feb. & Stetson & JMZ-WHOI & V & & $1: 16,312$ \\
\hline 95621 Feb. & & JMZ-WHOI & V & & $1: 15,689$ \\
\hline
\end{tabular}




\section{AERIAL PHOTOGRAPHS OF NAUSET INLET}

\begin{tabular}{|c|c|c|c|c|c|c|}
\hline Year & Date & $\begin{array}{c}\text { otographed } \\
\text { By }\end{array}$ & $\begin{array}{l}\text { Obtained } \\
\text { From }\end{array}$ & $\begin{array}{l}\text { tical/ } \\
\text { ique }\end{array}$ & Frame \#('s) & Scale \\
\hline 1956 & 9 Mar. & & JMZ-WHOI & V & & $1: 15,723$ \\
\hline 1956 & 27 May & Stetson & JMZ-WHOI & v & & 7: \\
\hline 1956 & Summer & Stetson & JMA-WHOI & V & & \\
\hline 1956 & 14 Sept. & & JMZ-WHOI & v & & $1: 5168$ \\
\hline 1956 & 26 oct. & Stetson & JMZ-WHOI & V & & \\
\hline 1957 & $210 \mathrm{ct}$. & Stetson & JMZ-WHOI & v & & $1: 17,686$ \\
\hline 1957 & 6 Nov. & Stetson & JMZ-WHOI & v & & \\
\hline 1957 & 21 Nov. & Stetson & JMZ-WHOI & v & & \\
\hline 1957 & $19 \mathrm{Dec}$ & & VIMS (RJB) & V & & $1: 17,686$ \\
\hline 1958 & 13 Mar. & & JMZ-WHOI & v & & $1: 17,750$ \\
\hline 1958 & $18 \mathrm{Mar}$. & Stetson & JMZ-WHOI & 0 & & \\
\hline 1958 & 17 July & & JMZ-WHOI & v & & \\
\hline 1958 & 11 Aug. & & JMZ-WHOI & v & & $1: 16,195$ \\
\hline 1958 & 23 Sept. & & JMZ-WHOI & v & & $1: 16,440$ \\
\hline 1959 & $14 \mathrm{Jan}$. & & VIMS (RJB) & v & & \\
\hline 1959 & 8 sept. & & VIMS (RJB) & v & & \\
\hline 1960 & 27 Feb. & & USNPS & v & $\begin{array}{l}\text { TR-3-60-1561 } \\
\text { thru } 67\end{array}$ & \\
\hline 1960 & Apri1 & FAS & FAS & & $C-24490-P$ & \\
\hline 1960 & 20 April & TDG & TDG & & $\begin{array}{l}23831-3 \\
540,542,558 \\
560,562\end{array}$ & $7: 6955$ \\
\hline 1960 & 6 May & USAF & EROS & V & & $1: 60,147$ \\
\hline 1960 & 13 Sept. & & JMZ-WHOI & v & & $1: 12,575$ \\
\hline
\end{tabular}




\section{AERIAL PHOTOGRAPHS OF NAUSET INLET}

\begin{tabular}{|c|c|c|c|c|c|c|}
\hline Year & Date & $\begin{array}{l}\text { tographed } \\
\text { By }\end{array}$ & $\begin{array}{l}\text { Obtained } \\
\text { From }\end{array}$ & $\begin{array}{l}\text { tical/ } \\
\text { ique }\end{array}$ & Frame \#('s) & Scale \\
\hline 1961 & 10 JuTy & & VIMS (RJB) & V & & \\
\hline 1962 & 23 Mar & USC\&GS & NOS & V & 53080,3082 & $1: 18,746$ \\
\hline 1965 & 21 Apri1 & LKBI & LKBI & V & $5520 ; 52-624$ & $1: 40,060$ \\
\hline 1965 & 11 June & & VIMS (RJB) & V & & $7: 5540$ \\
\hline 1965 & 25 Aug. & & VIMS (P.JB) & V & & $1: 6466$ \\
\hline 1966 & 25 Aug & & VIMS (RJB) & v & & $1: 11,445$ \\
\hline 1966 & Nov. & RK & RK & 0 & & \\
\hline 1967 & 30 May & & NED & V & & $7: 9514$ \\
\hline 1968 & 13 July & PK & RK & 0 & & \\
\hline 1968 & 21 Nov. & PK & RK & 0 & & \\
\hline 1968 & $6 \mathrm{Dec}$. & PK & RK & V & $33 \& 28$ & $1: 6466$ \\
\hline 1968 & 6 Dec. & PK & RK & 0 & & \\
\hline 1969 & 15 July & RK & RK & 0 & & \\
\hline 1969 & oct. & & CERC & V & & $1: 12,812$ \\
\hline 1970 & 28 May & RK & RK & 0 & & \\
\hline 1970 & 5 Aug. & USGS & WHOI & 0 & & \\
\hline 1970 & 5 Aug. & RK & RK & 0 & & \\
\hline 1970 & 3 Sept. & RK & RK & 0 & & \\
\hline 1970 & 12 Sept. & USC\&GS & NOS & V & & $1: 19,412$ \\
\hline 1970 & 20 Sept. & ASCS & USNPS & V & $\mathrm{DPL} \quad 171-80$ & $7: 40,287$ \\
\hline 1970 & 24 Sept. & USGS & EROS & V & R. $01170-10-3$ & $1: 25,419$ \\
\hline 1971 & 28 April & (NED) & UMAS & V & $\begin{array}{l}15544,2942 \& \\
43 ; \operatorname{RF} 6813\end{array}$ & \\
\hline
\end{tabular}




\section{AERIAL. PHOTOGRAPHS OF NAUSET INLET}

\begin{tabular}{|c|c|c|c|c|c|}
\hline Year Date & $\begin{array}{c}\text { hotographed } \\
\text { By }\end{array}$ & $\begin{array}{l}\text { Obtained } \\
\text { From }\end{array}$ & $\begin{array}{l}\text { Vertical/ } \\
\text { oblique }\end{array}$ & Frame \#('s) & Scale \\
\hline 197115 May & RK & RK & 0 & & \\
\hline 19717 Aug. & ASCS & WHOI & v & $D P L-2 m m-211$ & $1: 26,960$ \\
\hline $19715 \mathrm{Dec}$. & RK & RK & 0 & & \\
\hline 19725 April & RK & RK & 0 & & \\
\hline 1972 May & RK & RK & 0 & & \\
\hline 197227 May & LKBI & LKBI & v & $\begin{array}{l}2582 ; 2.434- \\
52-282\end{array}$ & $7: 42,876$ \\
\hline 197220 Aug. & RK & RK & 0 & & \\
\hline $197325 \mathrm{Mar}$. & & UMASS & v & G83 193 & $1: 18,988$ \\
\hline 19737 April & RK & RK & 0 & & \\
\hline 197329 Aug. & RK & RK & 0 & & \\
\hline 19737 Sept. & RK & RK & 0 & & \\
\hline 197421 Feb. & USGS & EROS & v & GS VD5T & $1: 23,937$ \\
\hline 197412 Aug. & RK & RK & v & $42,43 \& 44$ & $1: 8700$ \\
\hline 197425 Aug. & RK & RK & 0 & & \\
\hline 197411 oct. & NED & UMASS & v & & $1: 16,916$ \\
\hline $197424 \quad t$ & RK & RK & v & & \\
\hline 19752 Jan. & RK & PK & 0 & & \\
\hline 197518 Mar. & $\mathrm{COL}$ & $\mathrm{COL}$ & v & $7247-37-26$ & $1: 954,1$ \\
\hline 197525 Mar. & RK & RK & 0 & & \\
\hline 197511 Apri1 & RK & RK & 0 & & \\
\hline 197526 July & RK & RK & 0 & & \\
\hline 197520 Aug. & USGS & EROS & 02196 & & $1: 60,000$ \\
\hline
\end{tabular}




\section{AERIAL PHOTOGRAPHS OF NAUSET INLET}

Year Date Photographed Obtained Vertical/Frame \#('s) Scale By From oblique

\begin{tabular}{|c|c|c|c|c|c|c|}
\hline 197528 Aug. & PK & RK & 0 & & & \\
\hline 19755 oct. & RK & RK & 0 & & & \\
\hline 197511 Nov. & RK & RK & 0 & & & \\
\hline $19766 \mathrm{Jan}$. & RK & RK & 0 & & & \\
\hline $197623 \mathrm{Mar}$. & RK & RK & 0 & & & \\
\hline 1976 May/Nov. & REDI & REDI & v & $49 \& 51$ & & $1: 11,836$ \\
\hline 19763 June & RK & RK & 0 & & & \\
\hline 197623 Aug. & RK & PK & 0 & & & \\
\hline 197612 oct. & RK & PK & 0 & & & \\
\hline 19776 JuTy & RK & PK & 0 & & & \\
\hline 197710 Aug. & RK & RK & 0 & & & \\
\hline 19779 Sept. & RK & RK & V & & & \\
\hline 197730 Sept. & & NED & v & & & \\
\hline $197820 \mathrm{Feb}$. & PK & PK & 0 & & & \\
\hline 197828 Feb. & RK & RK & 0 & & & \\
\hline 19786 Mar. & NOS & UMASS & V & $\begin{array}{l}\text { LMI-632; } \\
80 \& 81\end{array}$ & 5979 & $1: 19,920$ \\
\hline 197818 Mar. & RK & PK & 0 & & & \\
\hline 197531 Mar. & JWS & USNPS & V & & & \\
\hline 197831 Mar. & RK & RK & 0 & & & \\
\hline 19786 Apri1 & RK & RK & 0 & & & \\
\hline 197810 Apri1 & RK & RK & 0 & & & \\
\hline 23 Aprit & & UMASS & v & & & $7: 23,350$ \\
\hline
\end{tabular}




\begin{tabular}{|c|c|c|c|c|c|c|}
\hline Year & Date & $\begin{array}{c}\text { lotographed } \\
\text { By }\end{array}$ & $\begin{array}{l}\text { Obtained } \\
\text { From }\end{array}$ & $\begin{array}{l}\text { Vertical/ } \\
\text { Oblique }\end{array}$ & Frame \#('s) & Scale \\
\hline 1978 & April/May & LMI & LMI & v & $x-12 \& 13$ & $1: 5013$ \\
\hline 1978 & 4 May & AVIS & AVIS & v & $\begin{array}{l}P 77871,2-36 \\
5,6 \& 7\end{array}$ & $1: 14,408$ \\
\hline 1978 & 10 June & RK & RK & 0 & & \\
\hline 1978 & 8 Nov. & RK & RK & 0 & & \\
\hline 1979 & $23 \mathrm{Jan}$. & RK & RK & v & $\begin{array}{l}51 \text { thru } 61, \\
10,12,13\end{array}$ & \\
\hline 1979 & 22 May & P.K & RK & v & 62 thru 70 & $1: 627$ \\
\hline 1979 & 27 May & RK & P.K & v & 23 thru 26 & $1: 8848$ \\
\hline 1979 & 27 June & Speer & WHOI & $\mathrm{V} / 0$ & & \\
\hline 1980 & 28 Mar. & Aubrey & WHOI & 0 & & \\
\hline 1980 & Aug. & WHOI & WHOI & 0 & & \\
\hline 1980 & 12 Sept. & Aubrey & WHOI & 0 & & \\
\hline 1980 & 27 oct. & Aubrey & WHOI & 0 & & \\
\hline 1981 & 14 Feb. & Aubrey & WHOI & 0 & & \\
\hline 1981 & 28 July & Aubrey & WHOI & 0 & & \\
\hline 1981 & 21 Sept. & $\mathrm{COL}$ & $\mathrm{COL}$ & v & & \\
\hline
\end{tabular}

\section{ABBREVIATIONS}

See Appendix III for most abbreviations

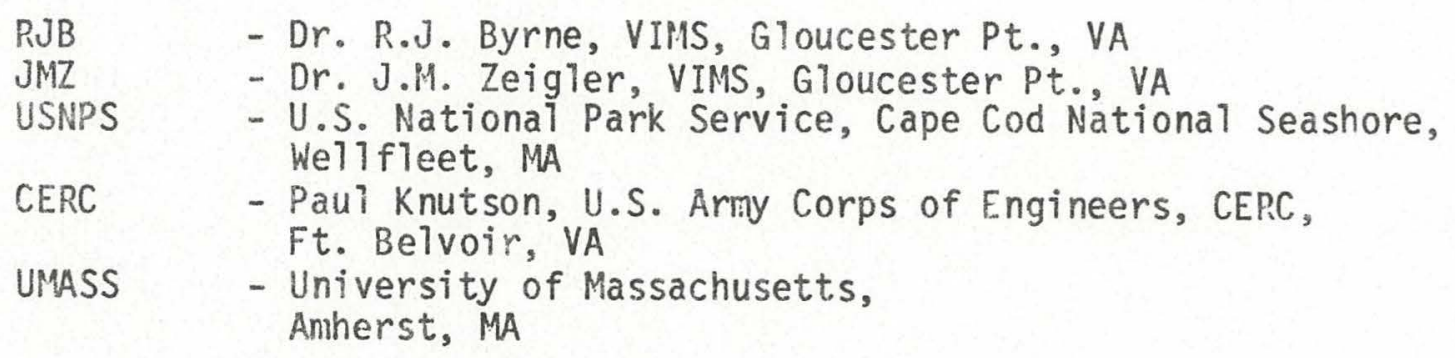




$$
-62 a-
$$


APPENDIX 3

DEPOSITORIES OF AERIAL PHOTOGRAPHY 


\section{APPENDIX 3 \\ DEPOSITORIES OF VERTICAL AERIAL PHOTOGRAPHS}

A. Private

APNE Aerial Photos of New England, Inc. Norwood Municipal Airport

Access Road, Norwood, MA 02062

AGC Aero-Graphics Corp.

Box 248, Bohemia, NY 11716

Alls Aero-Marine Surveys

38 Green Street, New London, CT 06320

AIT Air Image Technology

Boxboro Road, Stow, MA 01775

ANCO Anderson-Nichols Co.

150 Causeway Street, Boston, MA 02.114

AVIS Avis Air Map, Inc.

454 Washington Street, Braintree, MA 02184

BSC Boston Survey Consultants

263 Summer Street, Boston, MA 022.10

COL Col-East, Inc.

Harriman Airport, North

Adams, MA 01247

DFS Dutton Flying Service 239 Newton Road, Haverhill, MA 01830

FAS Fairchild Aerial Surveys

Los Angeles, CA

P.K Mr. Richard Kelsey

20 Heritage Lane, Chatham, MA

KAS Keystone Aerial Surveys, Inc.

North Philadelphia, PA

LKBI Lockwood, Kessler \& Bartlett, Inc.

One Aerial Way, Syosset, NY 11791

LMI Lockwood Mapping, Inc.

P.0. Box 5790,580 Jefferson

Rd., Rochester, NY 14623

LAPS Lowry Aerial Photo Service

234 Cabot Street, Beverly, MA 01915

NESS New England Survey Service

1220 Adams Street, Box 412, Dorchester, MA 02122 

NEAA Northeast Airphoto Association, Inc. 29 Grafton Circle, Shrewsbury, MA 02576
REDI Real Estate Data, Inc.
Northeast Division, 629 Fifth Avenue, P.0. Call Box D, Pelham, NY 10803
RAS Robinson Aerial Surveys
JWS James W. Seval1 Company
TDG Teledyne Geotronics
West Wareham, MA 02576
725 E. 3rd Street, Long Beach, CA 90802
WHOI Data Library
Woods Hole Oceanographic Institution, Wood Hole, MA 02543

B. Government

NED U.S. Army Corps of Engineers

USDA U.S. Department of Agriculture

NARS National Archives and Record Service

NCIC U.S. Department of Defense

and Soil Conservation Service, Cartographic Division, Federal Center Building No. 1, Hyattaville, MD 20782

General Services Administration, Cartographic Archives Division $\mathrm{Rm} 2 \mathrm{~W}, 8$ Pennsylavnia Avenue, NW, Washington, DC 20408

Central Film Library, U.S. Geological Survey, National Cartographic Infomation Center, National Center, Mail Stop 507, Reston, VA 2209?

EROS U.S. Department of Interior EROS Data Center, Sioux Falls, SD 57198

NOS Chief, Photo Map \& Imagery Section

Coastal Mapping Division, C3415, National Ocean Survey, NOAA, Rockville, MD 20852 
APPENDIX 4

TRACINGS OF SELECTED HISTORICAL MAPS AND PHOTOGRAPHS DOTS ON TRACINGS MARK REFERENCE POINTS. 


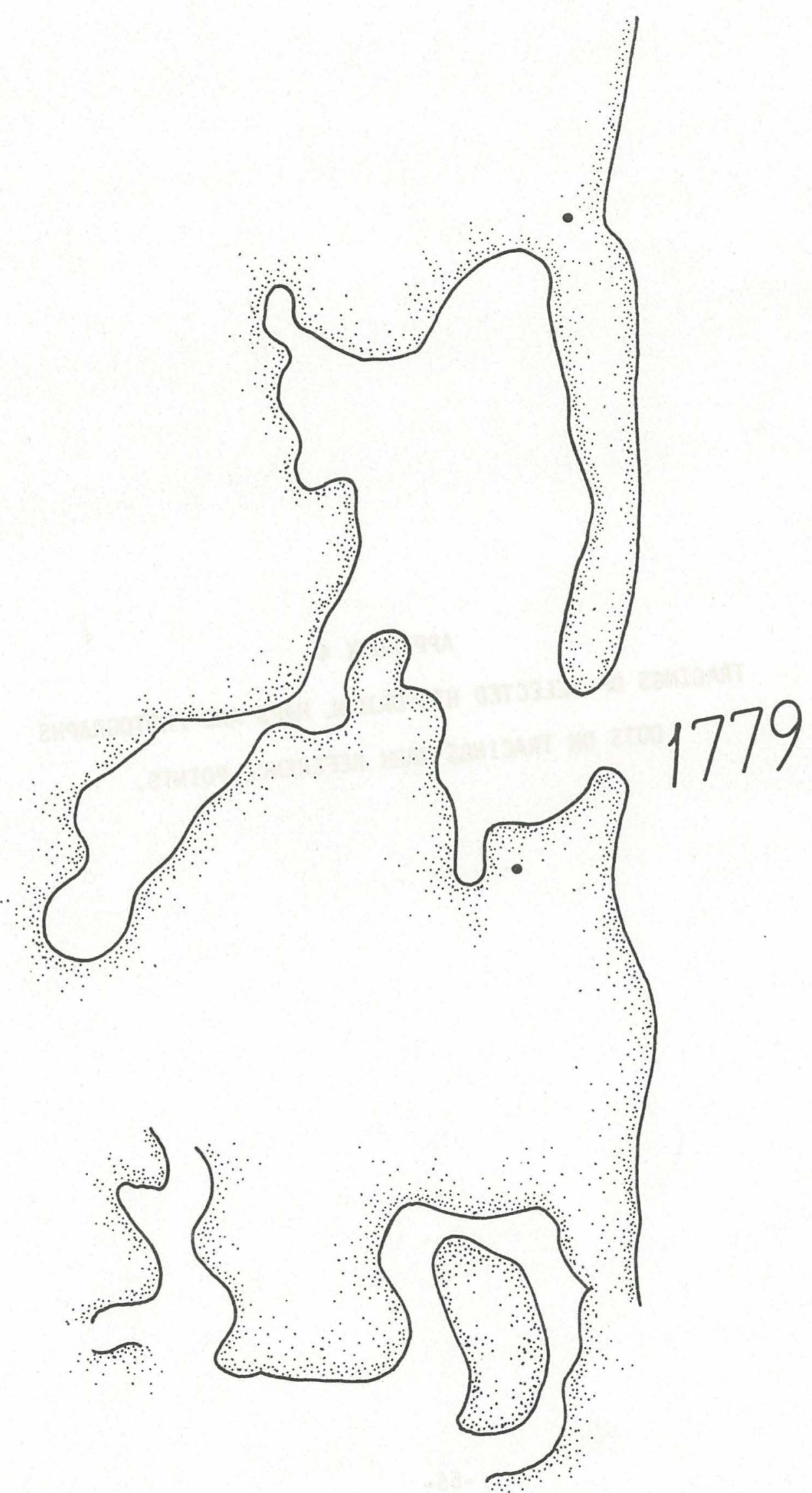

$-67-$ 


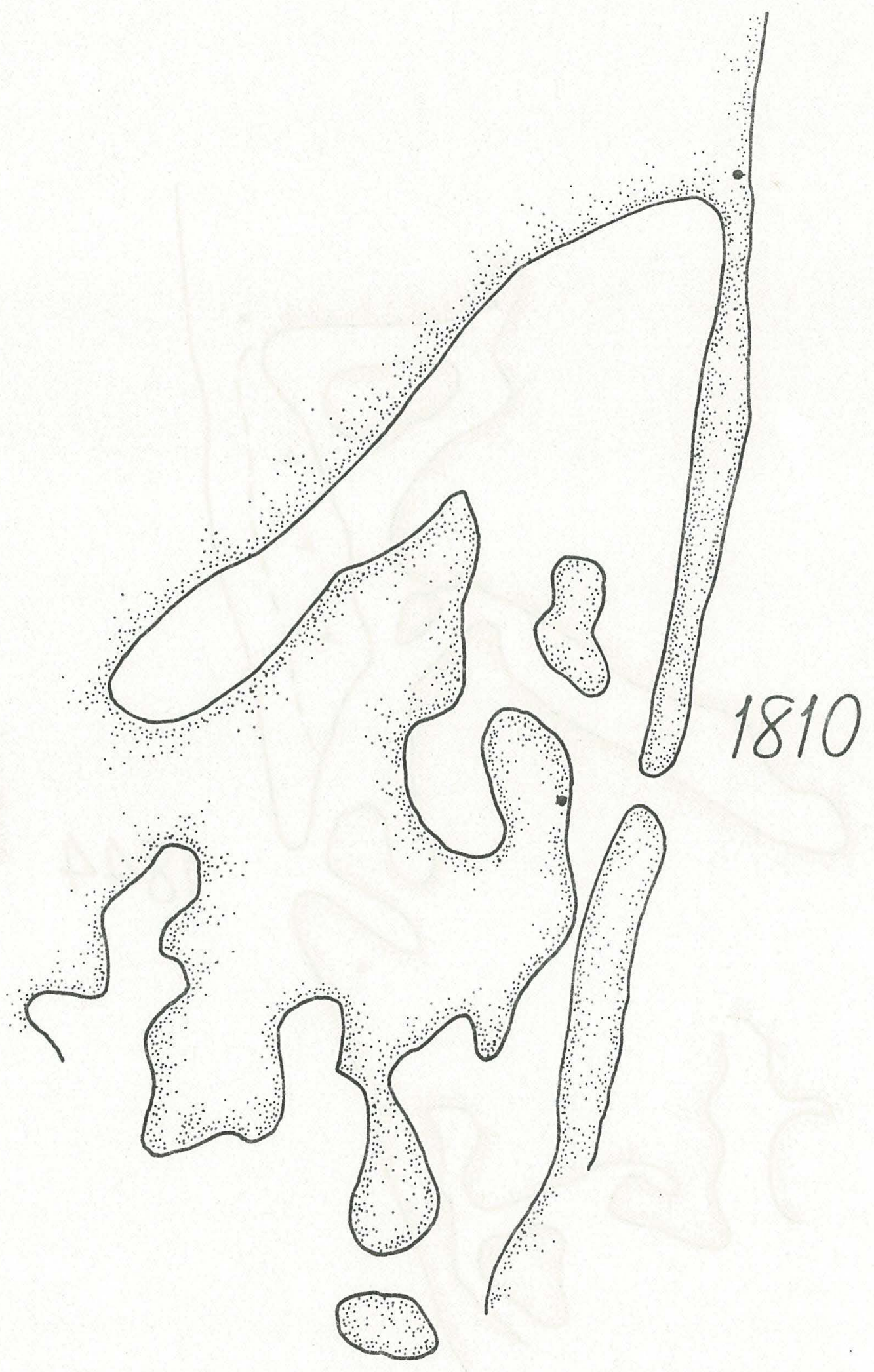




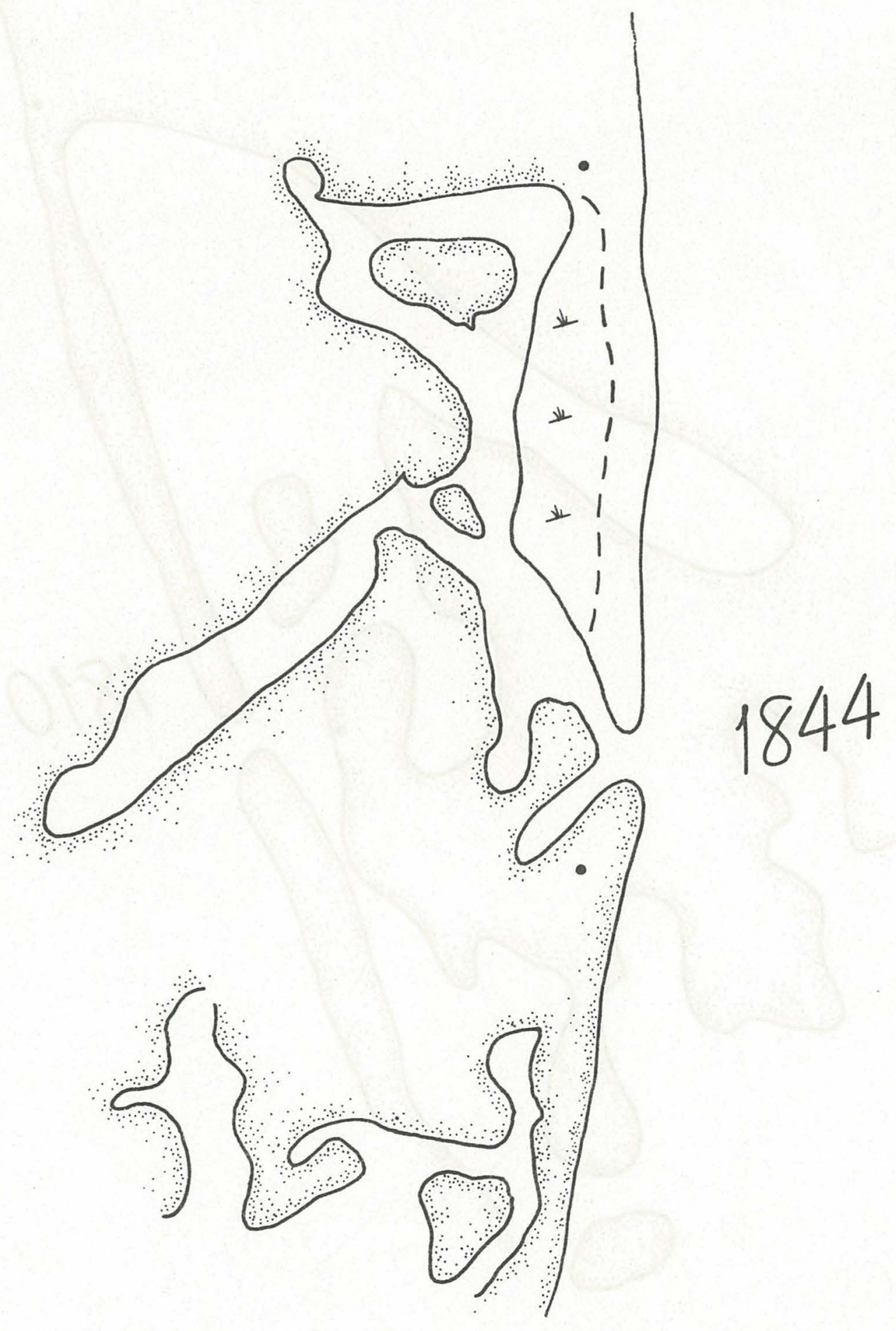

$-69-$ 


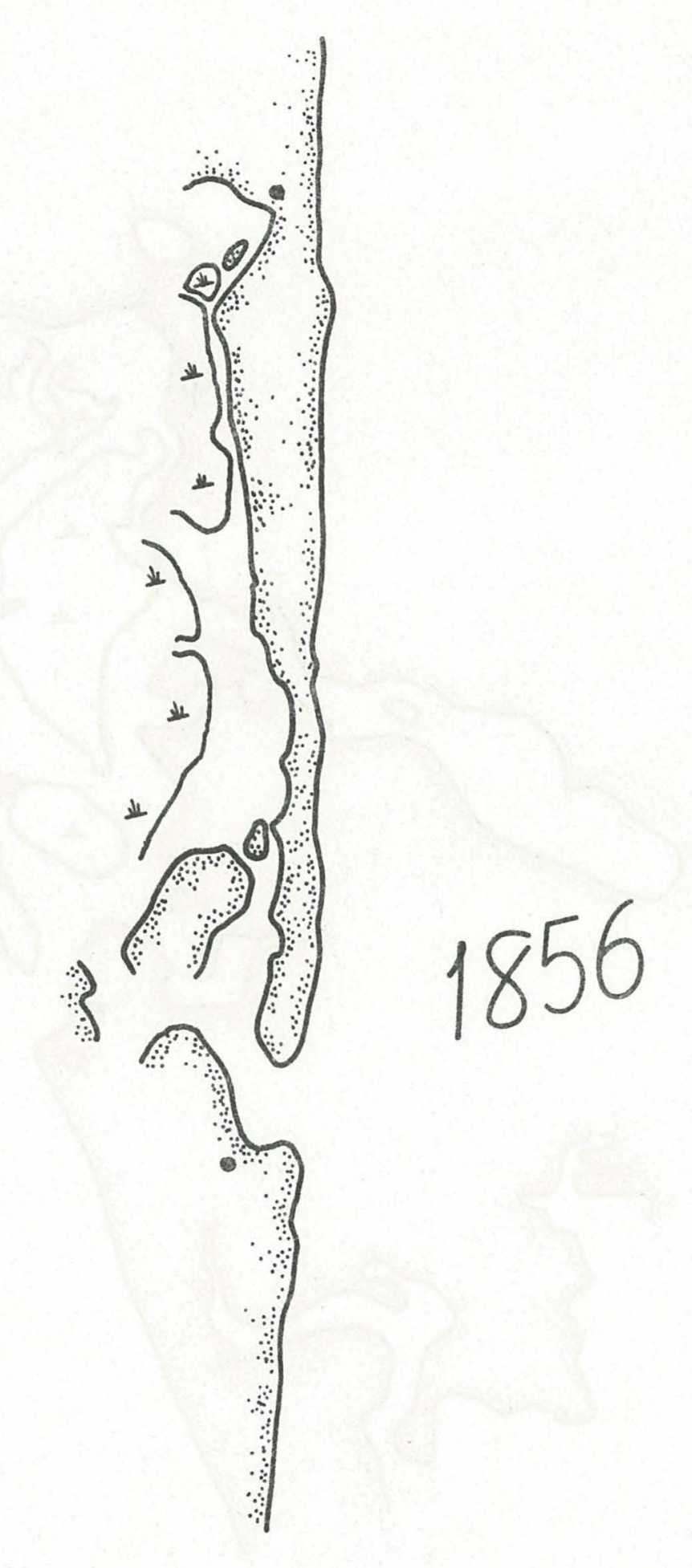




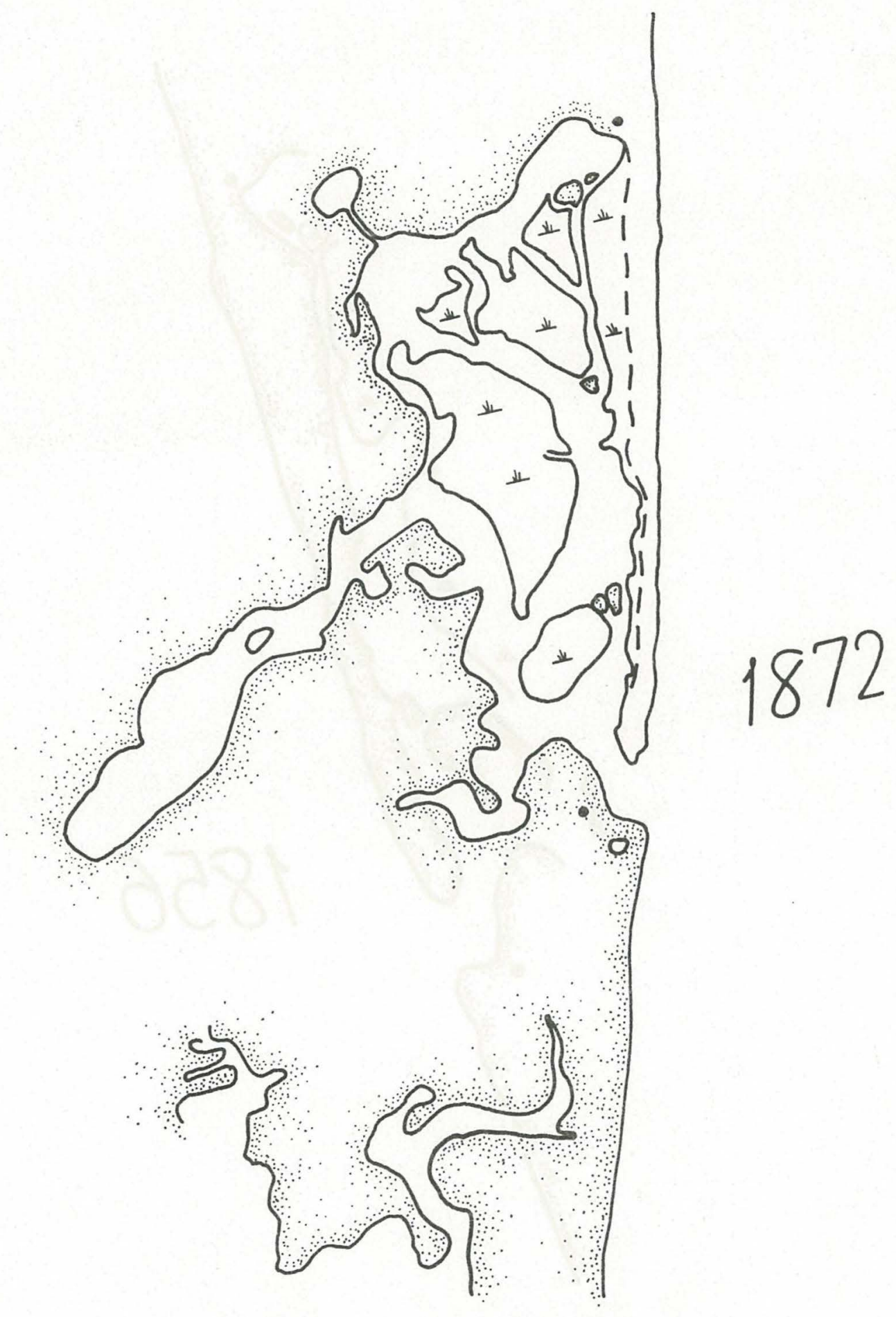




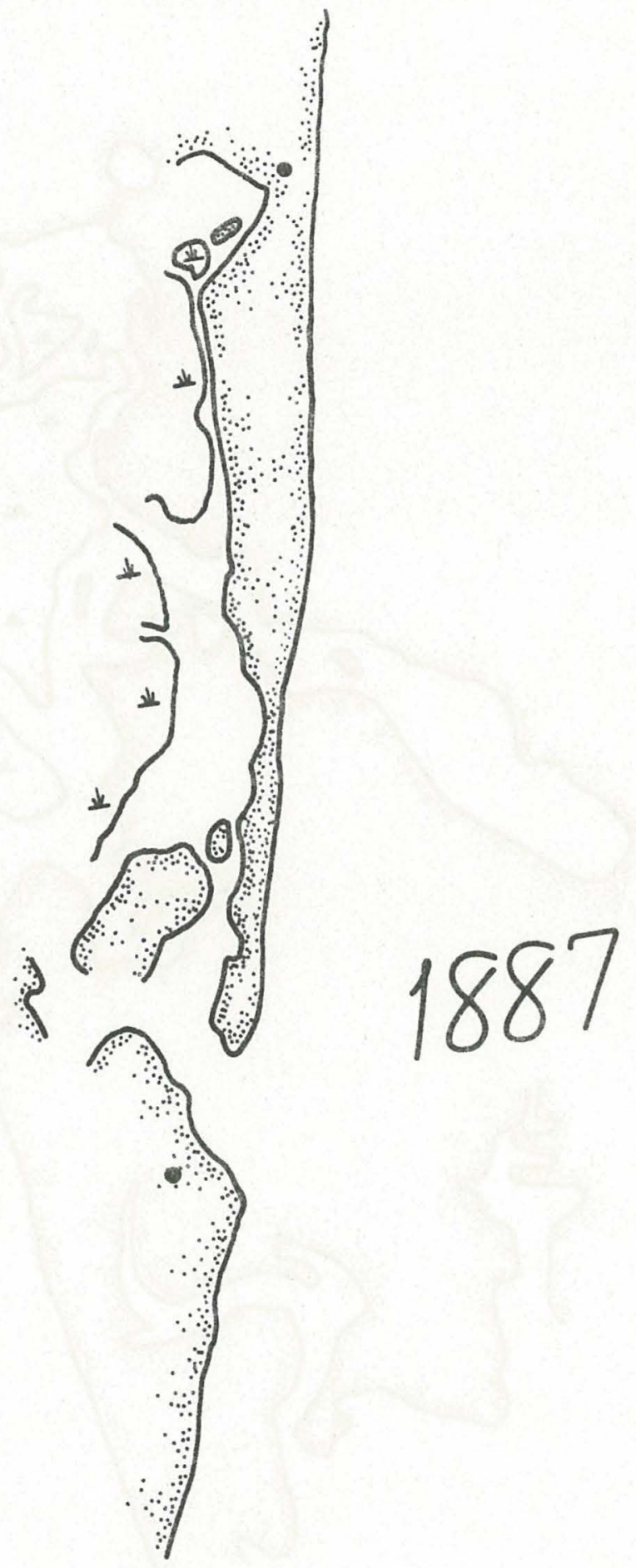




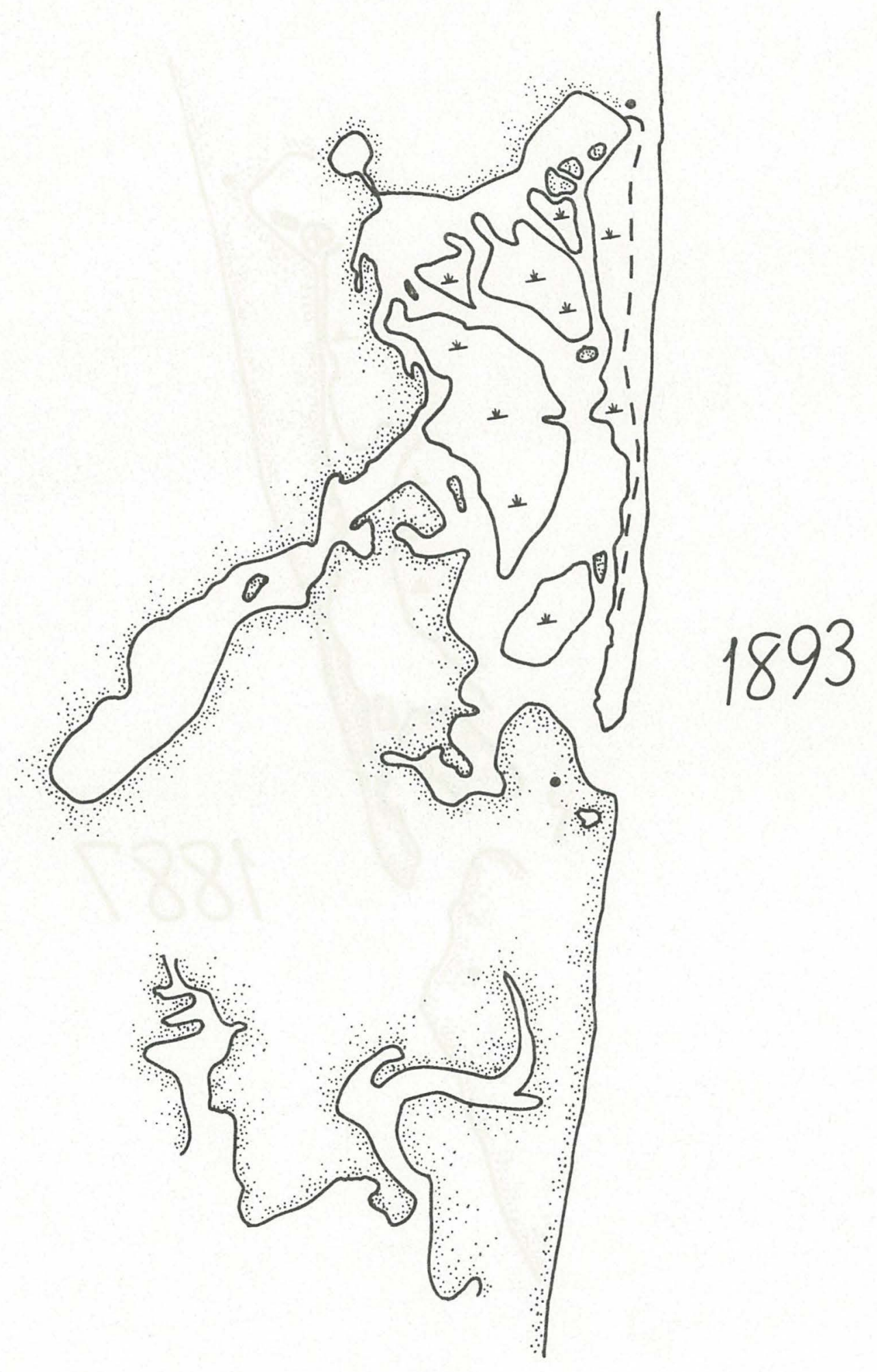




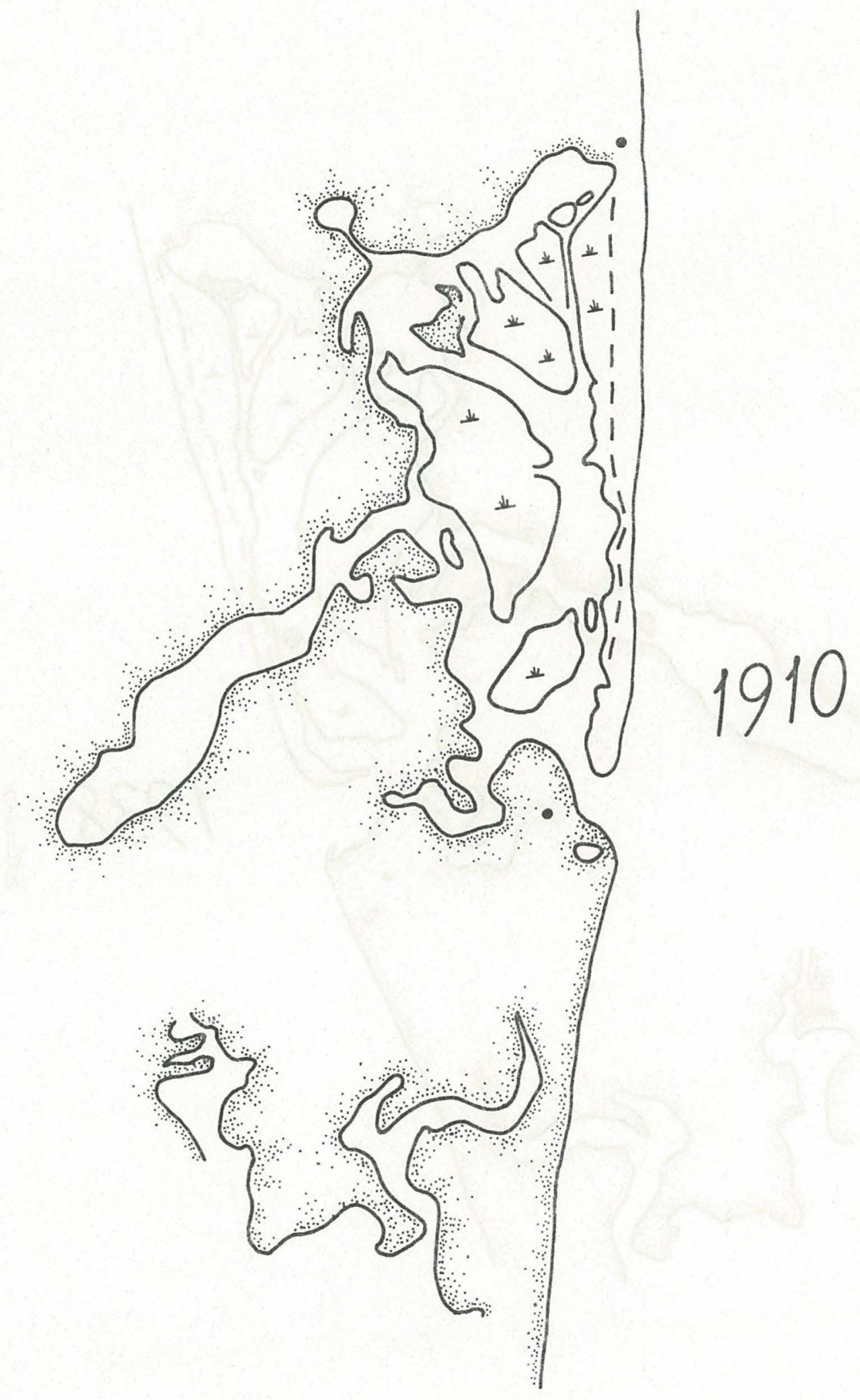




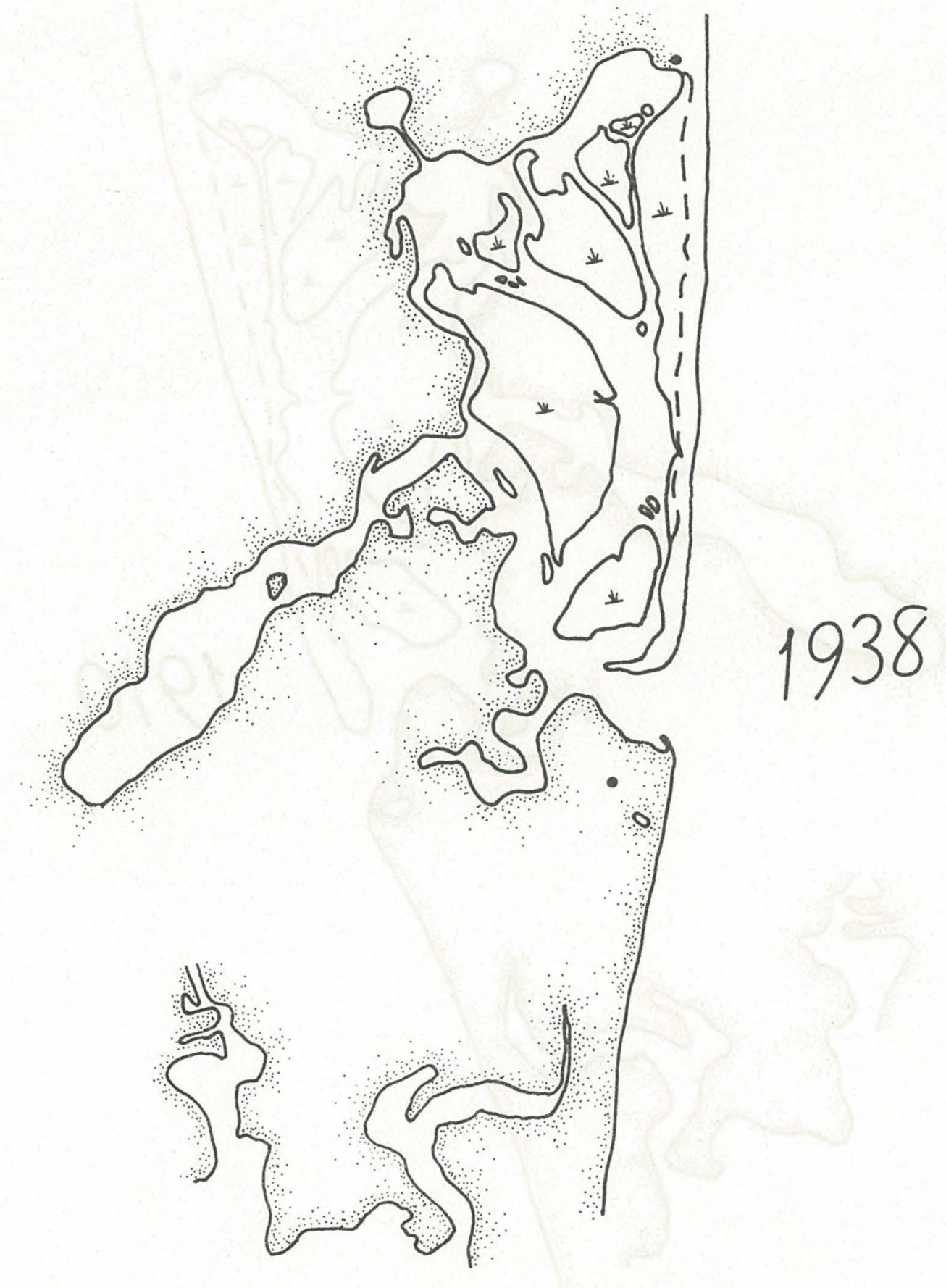




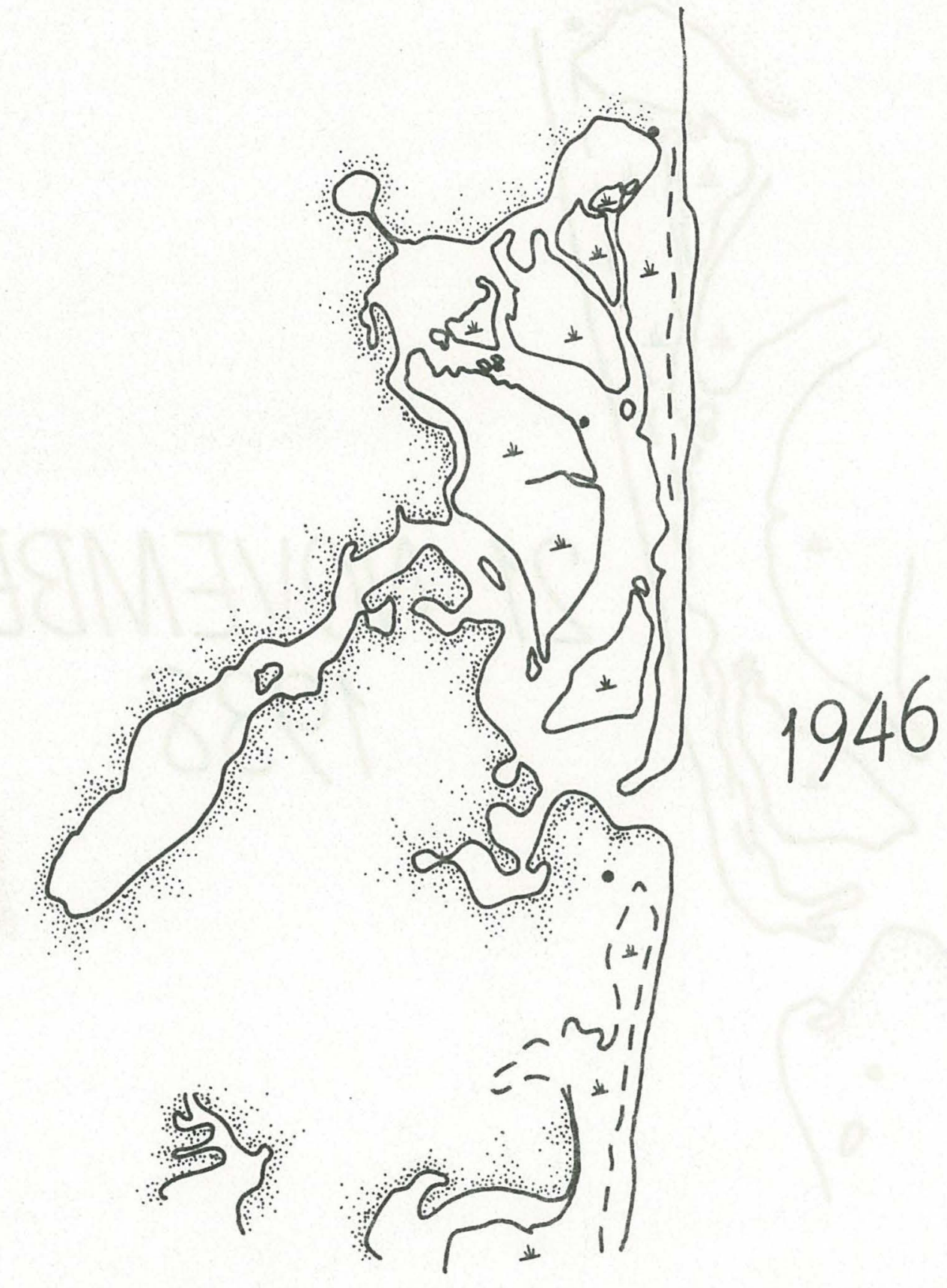




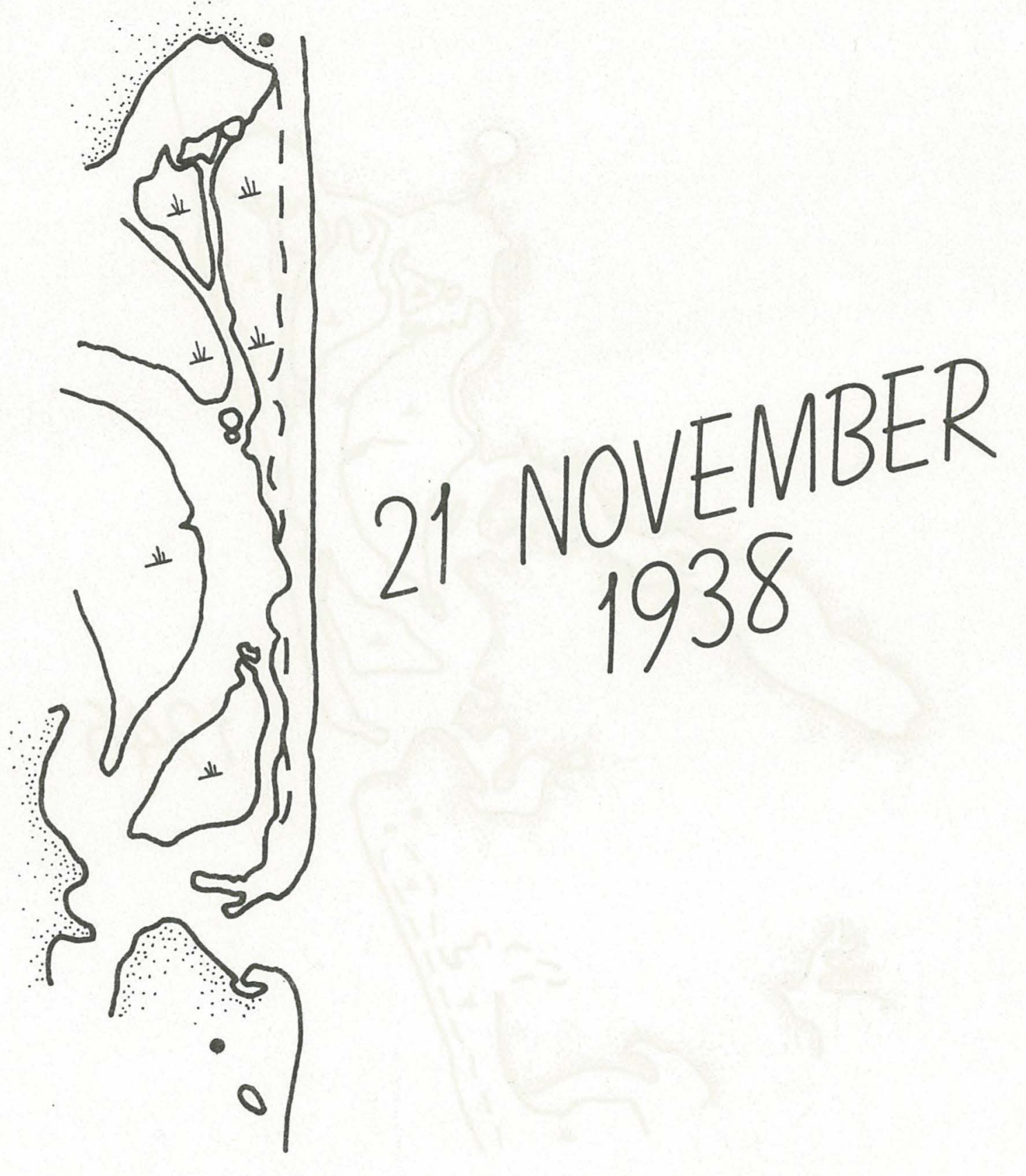




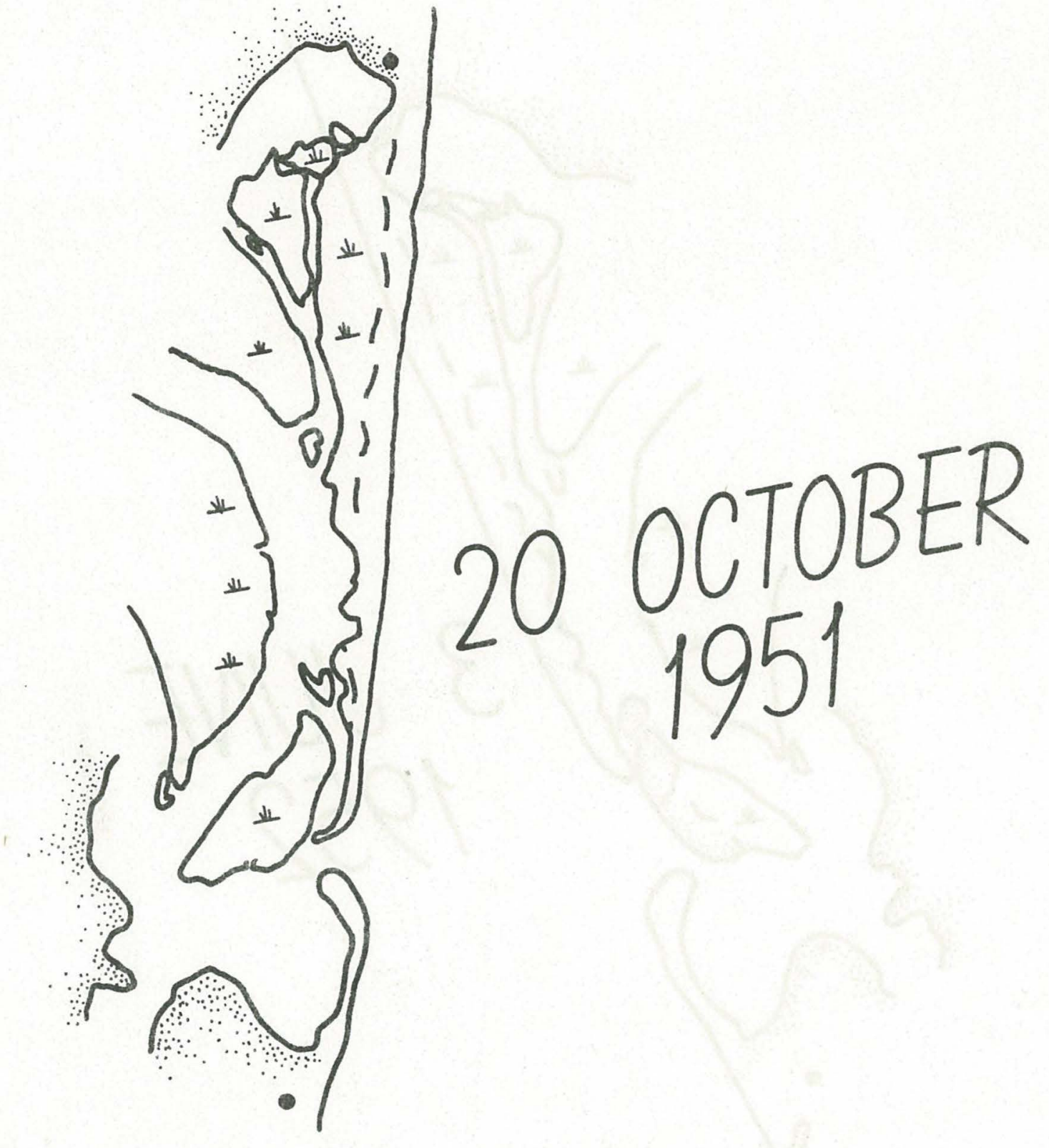




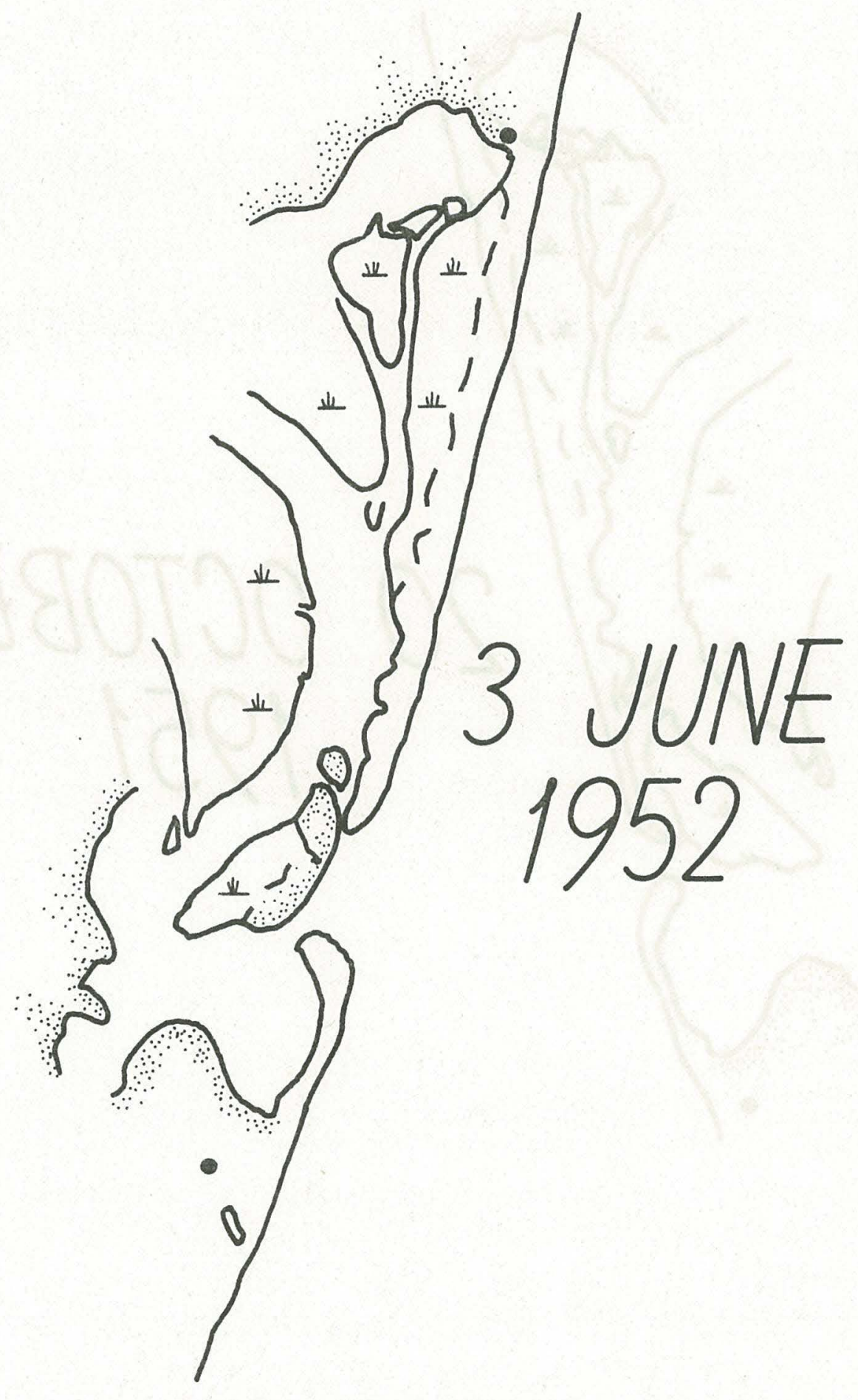




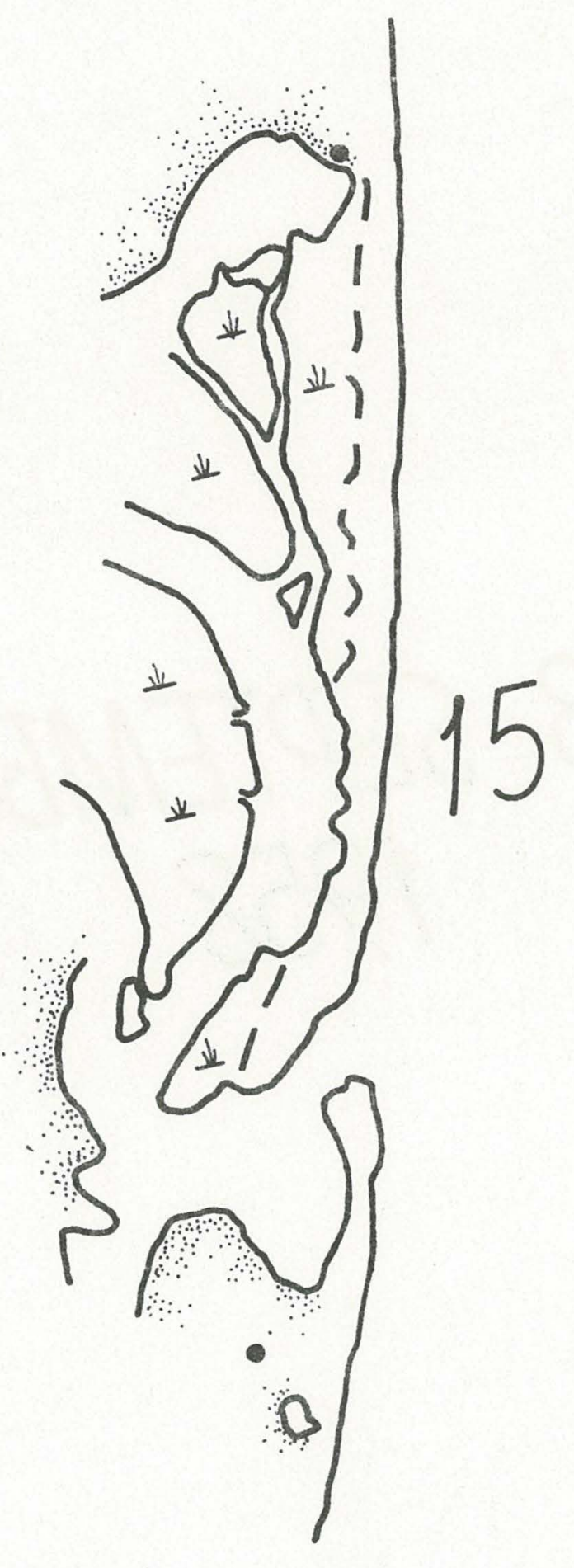

$-80-$ 


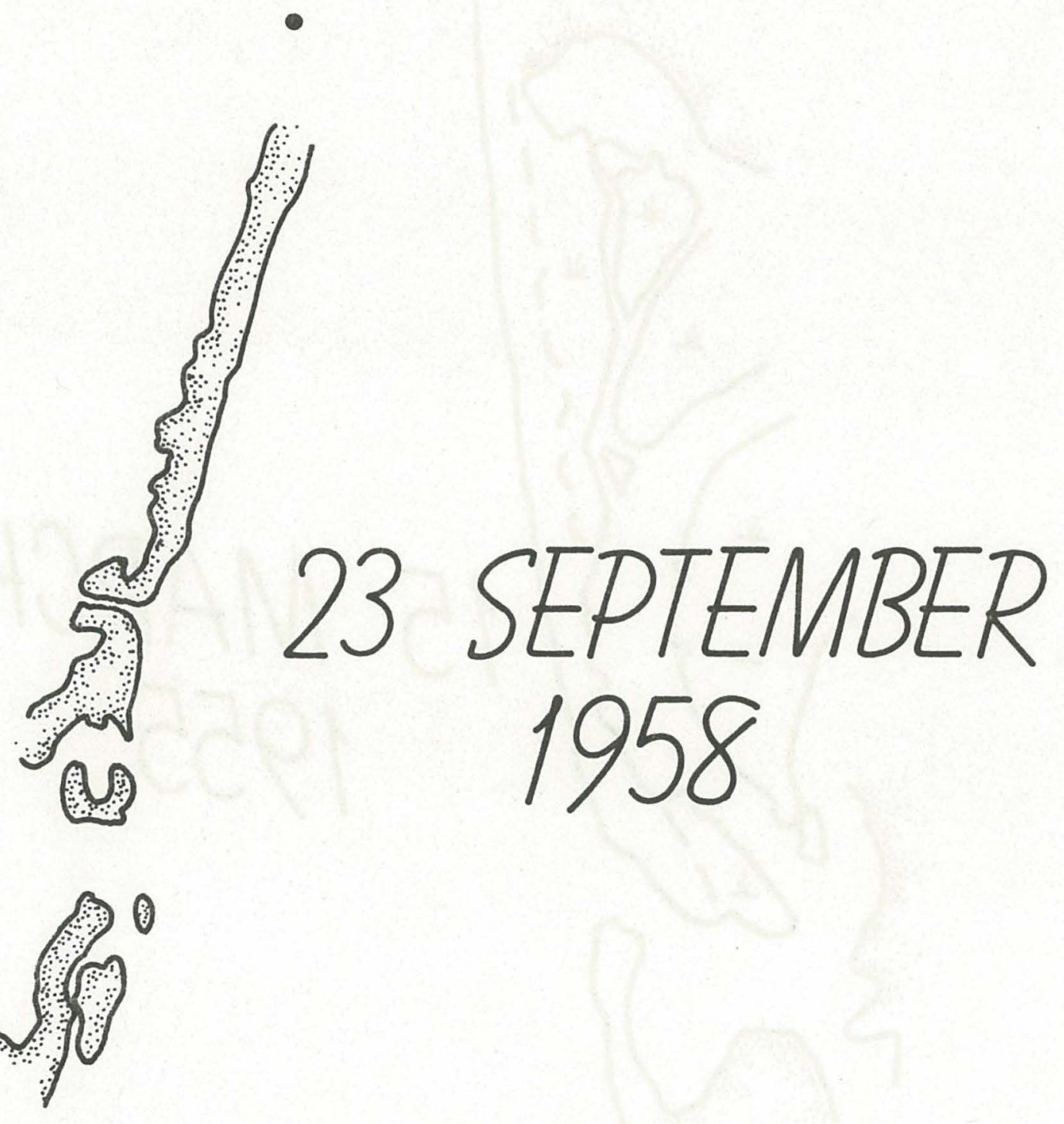




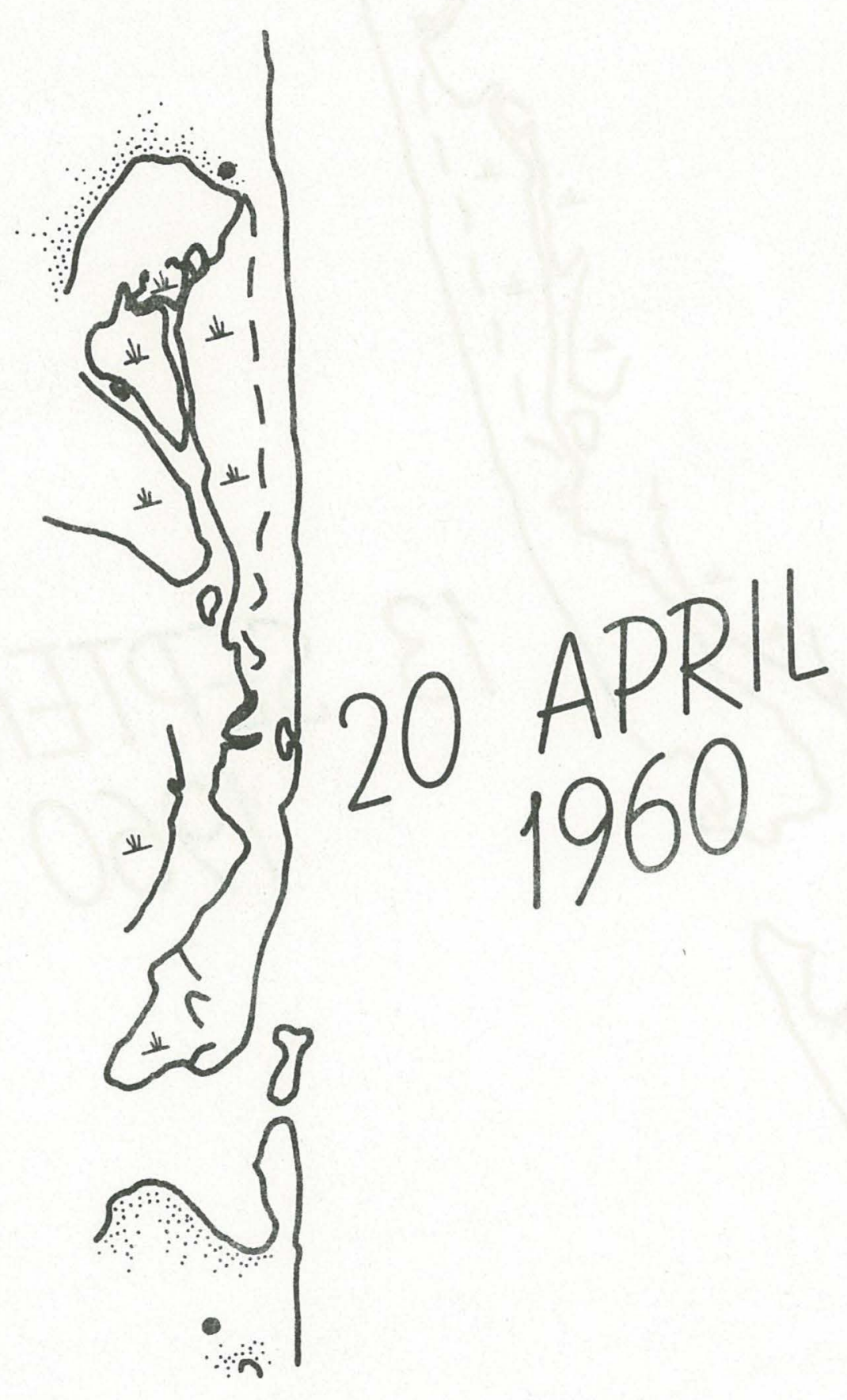



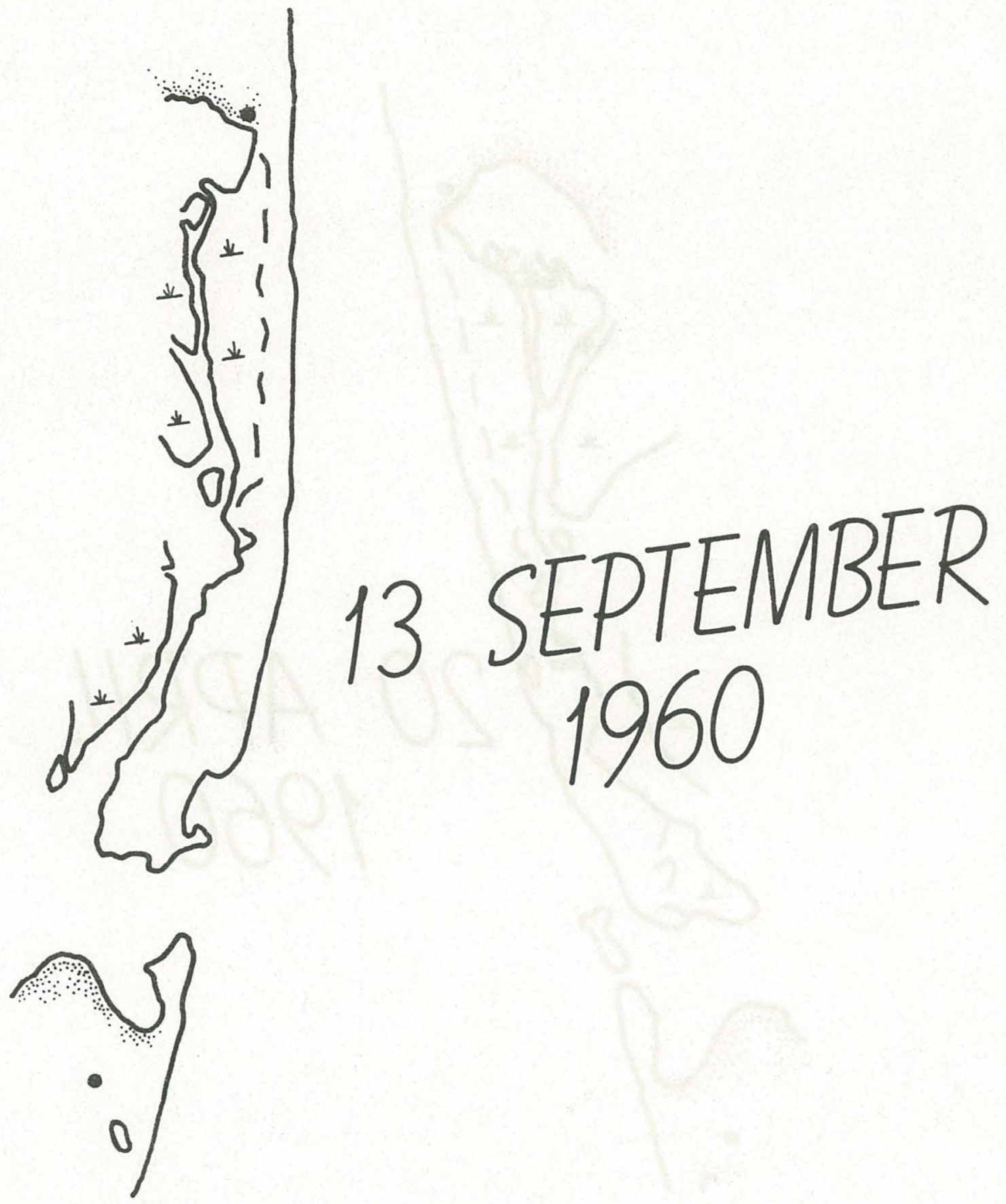


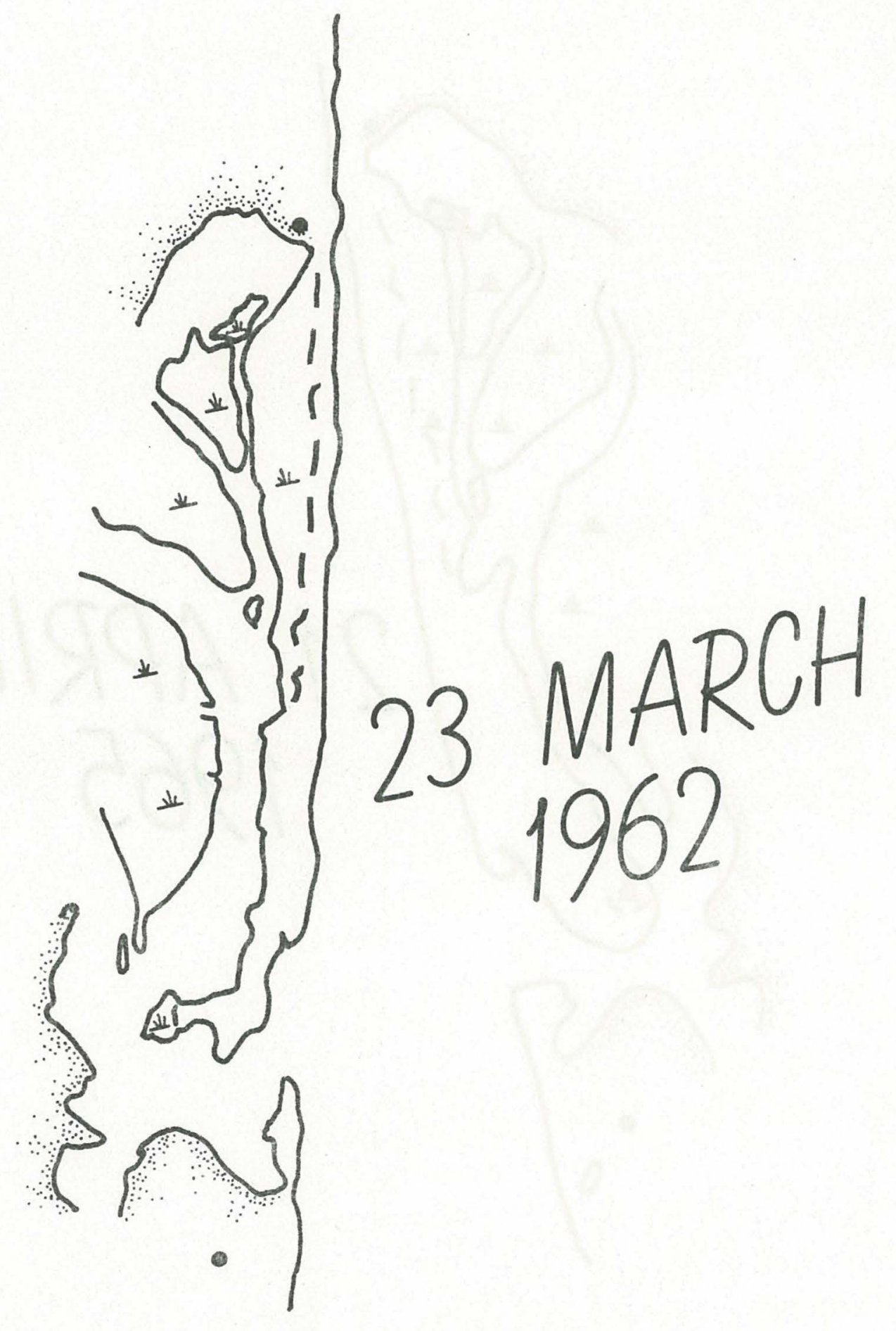

$-84-$ 


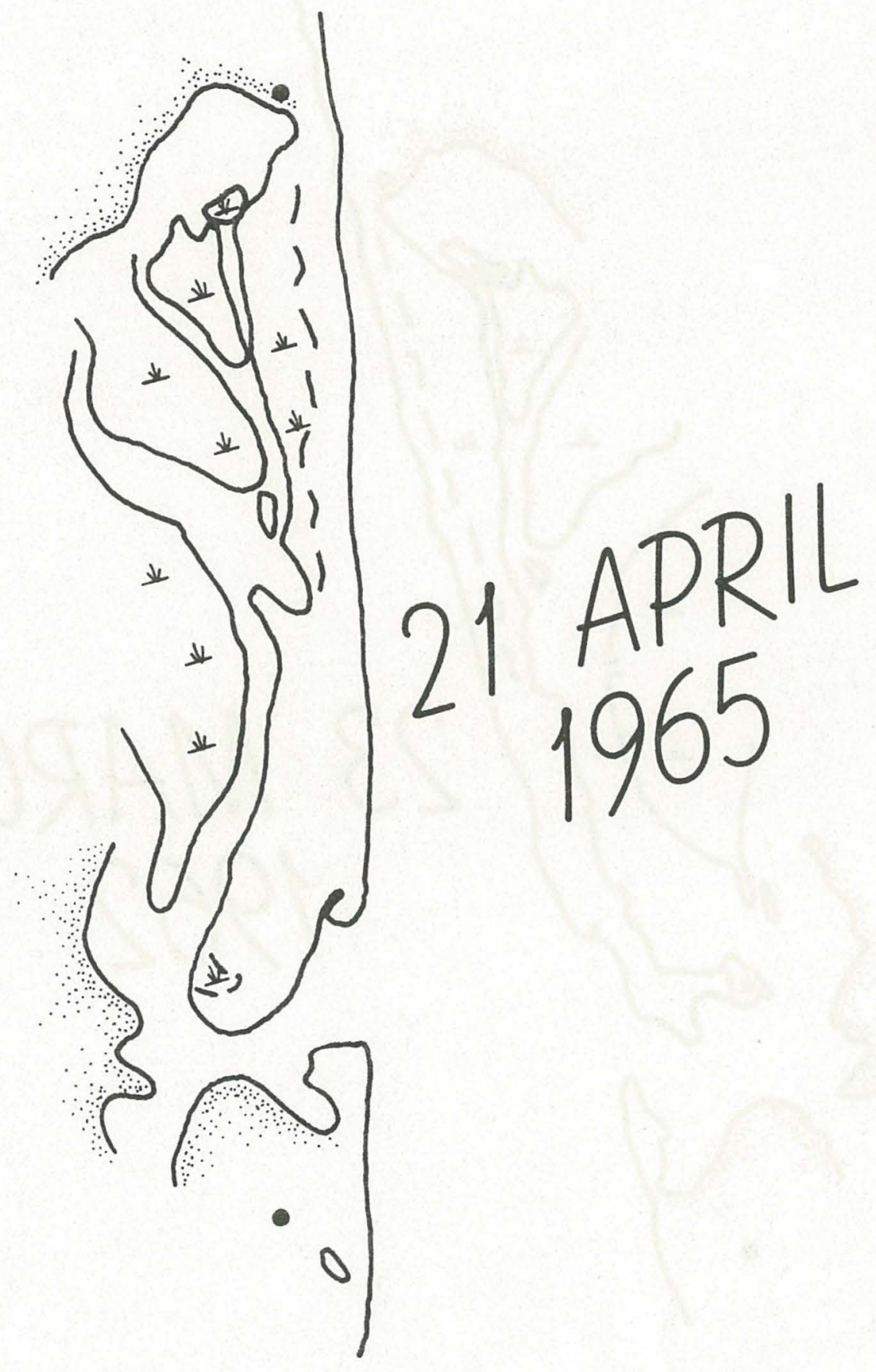




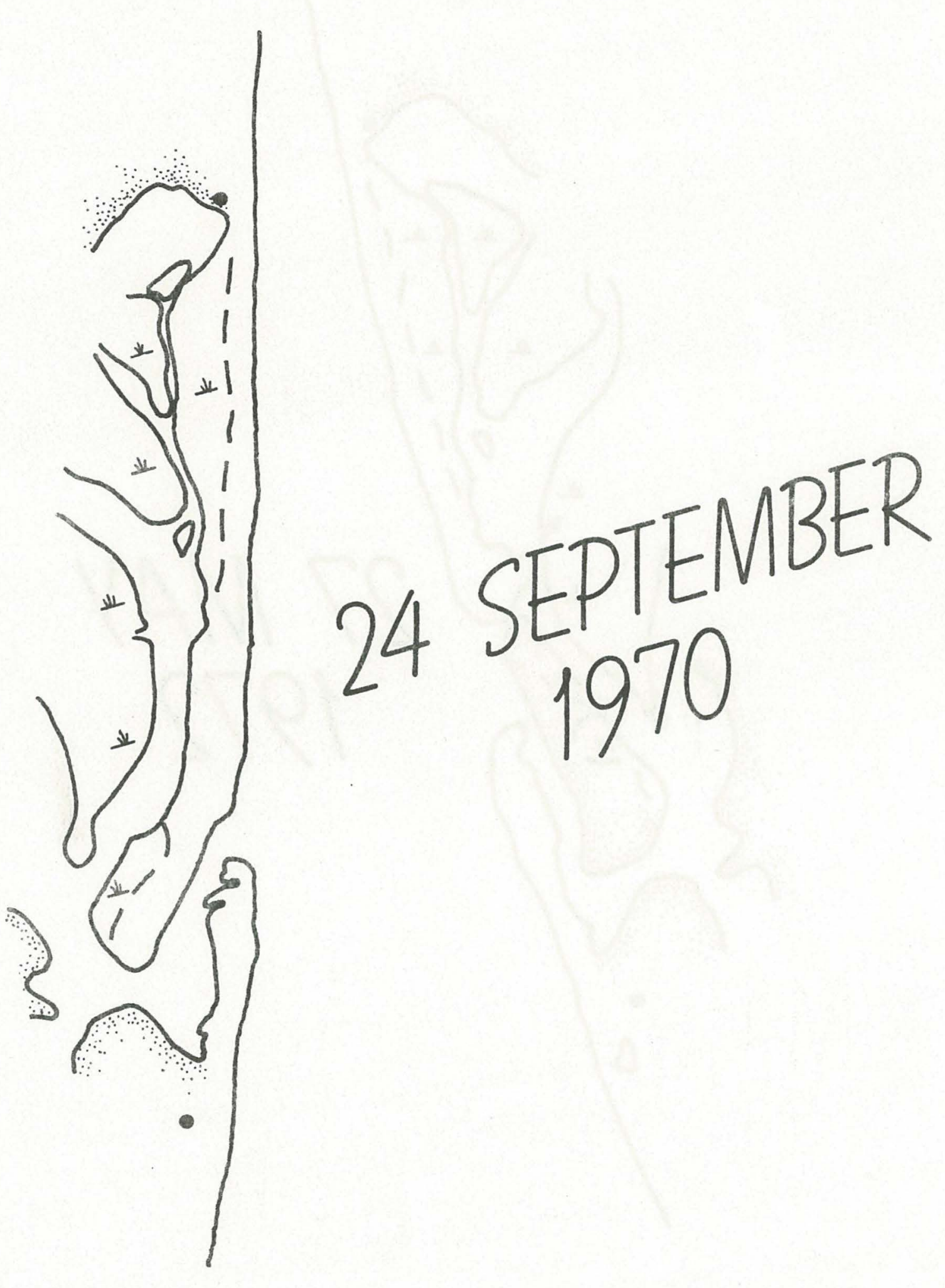




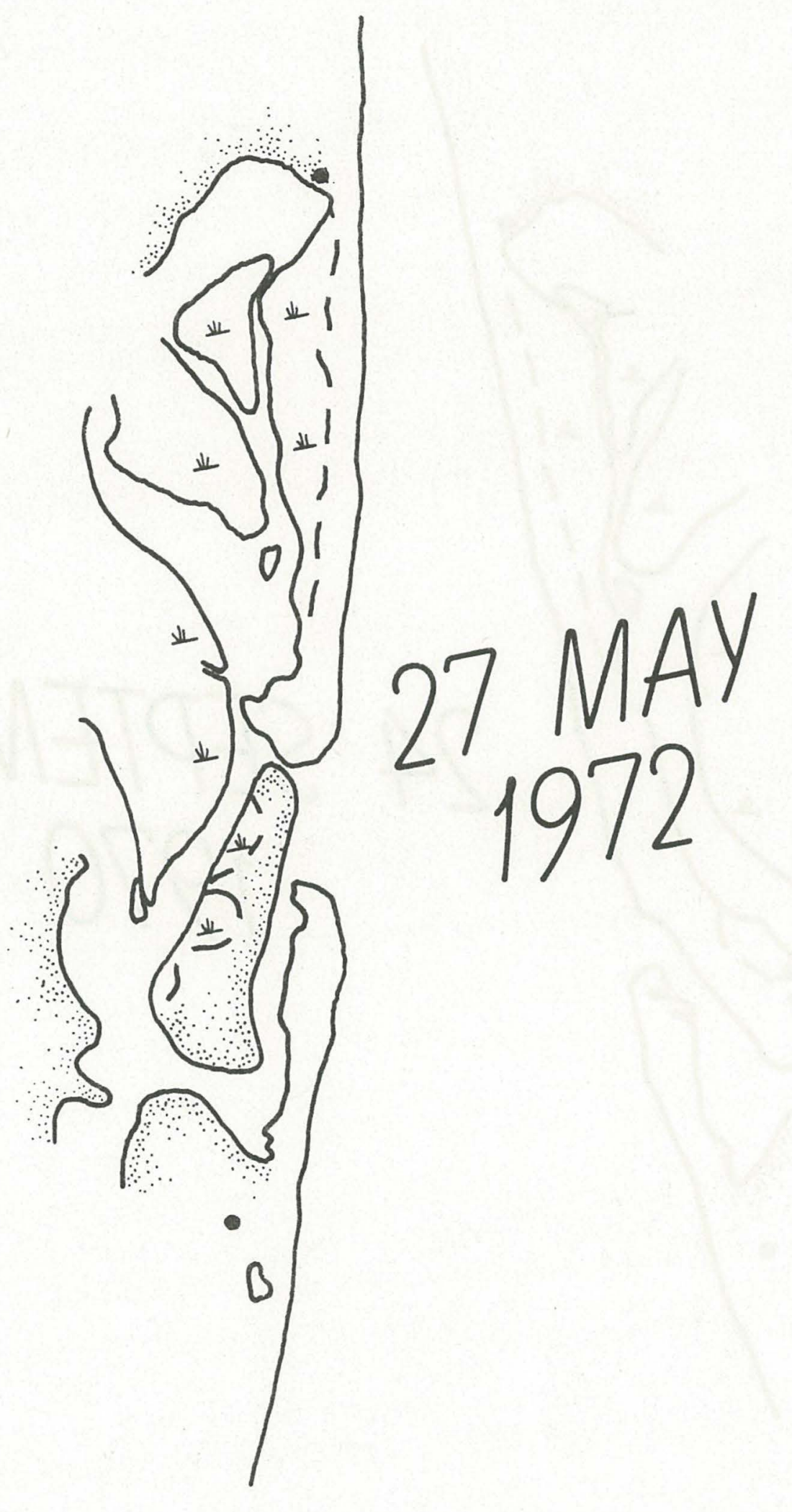

$-87-$ 


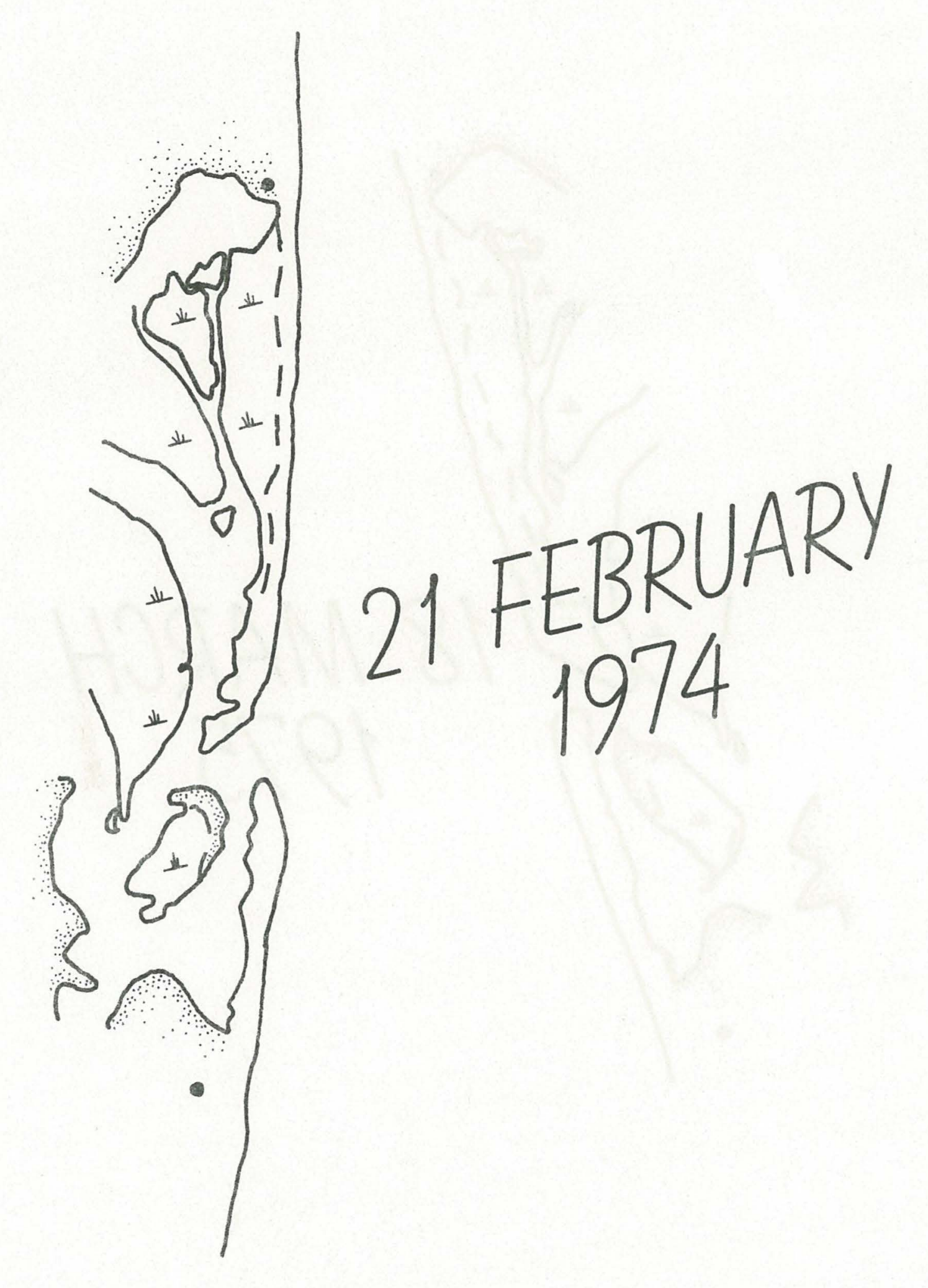




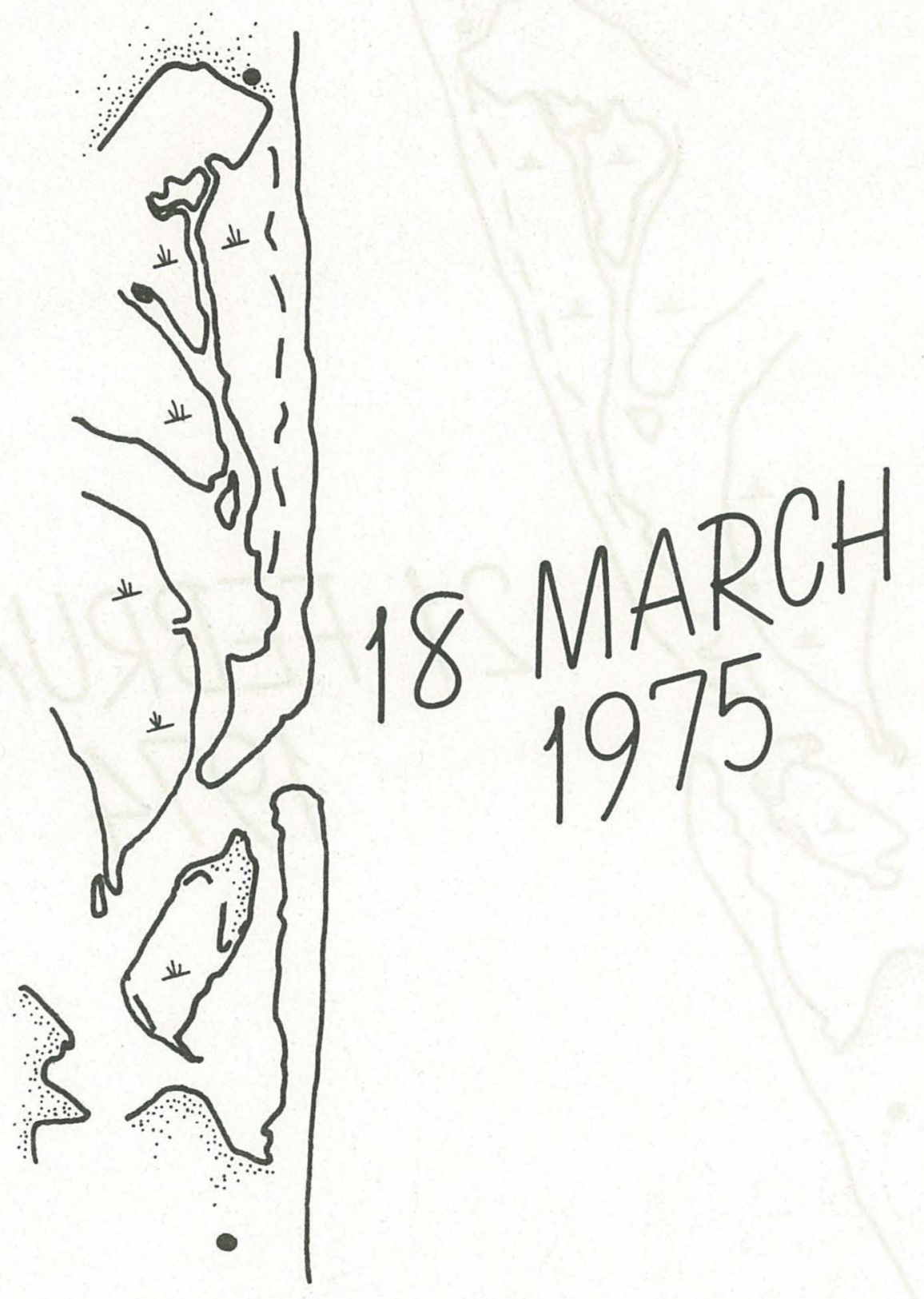

$-89-$ 


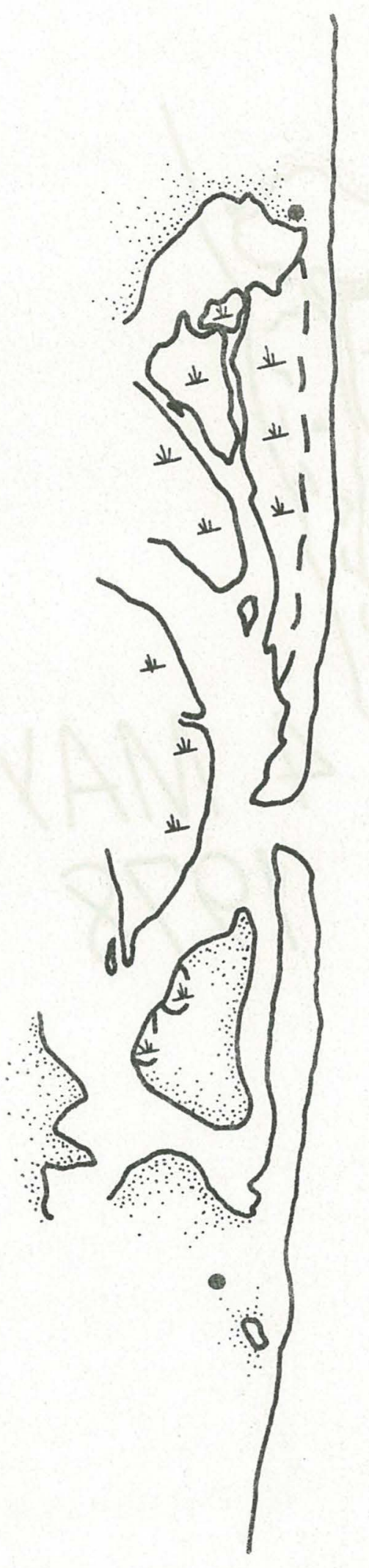

$.90-$ 


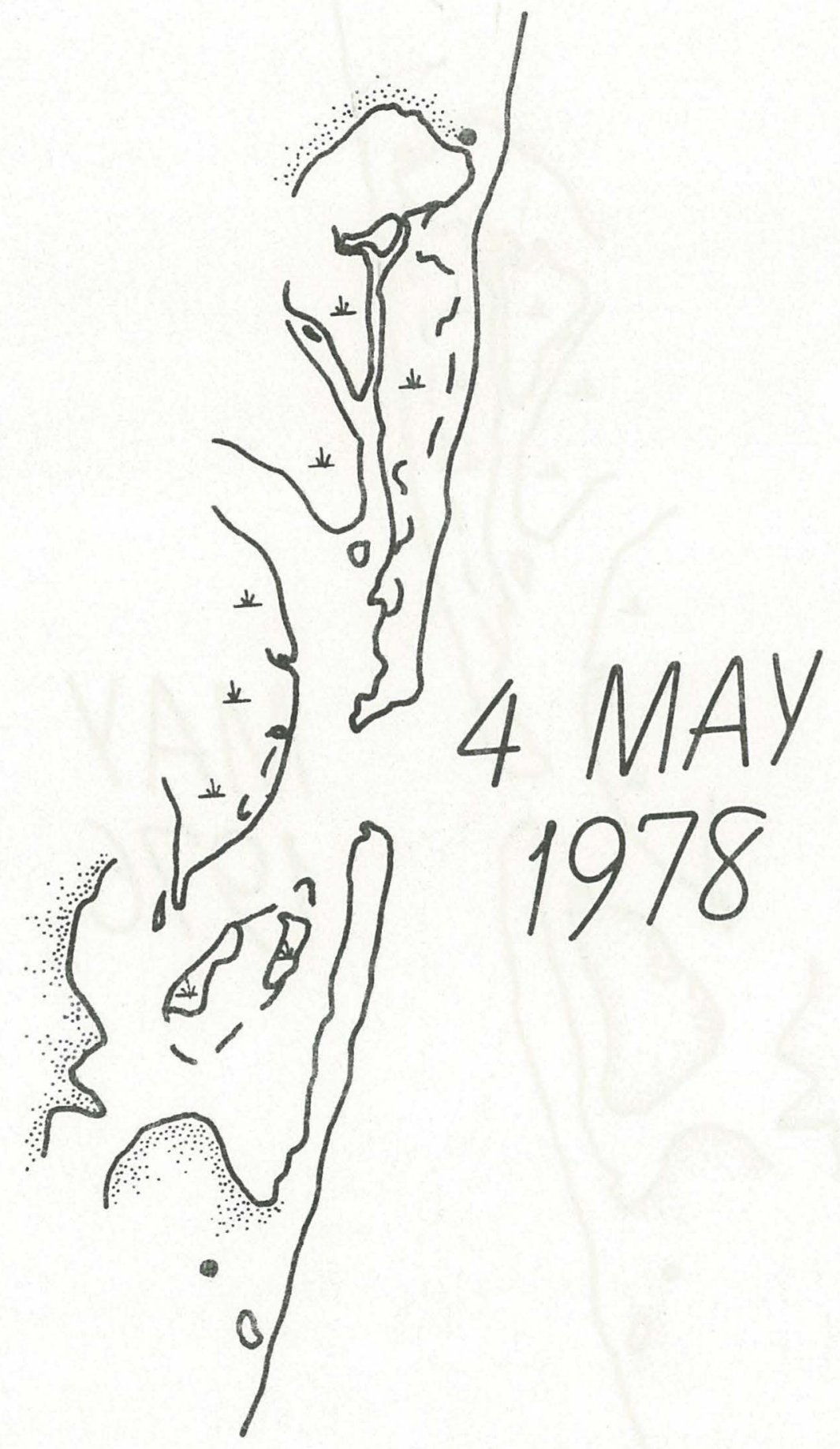




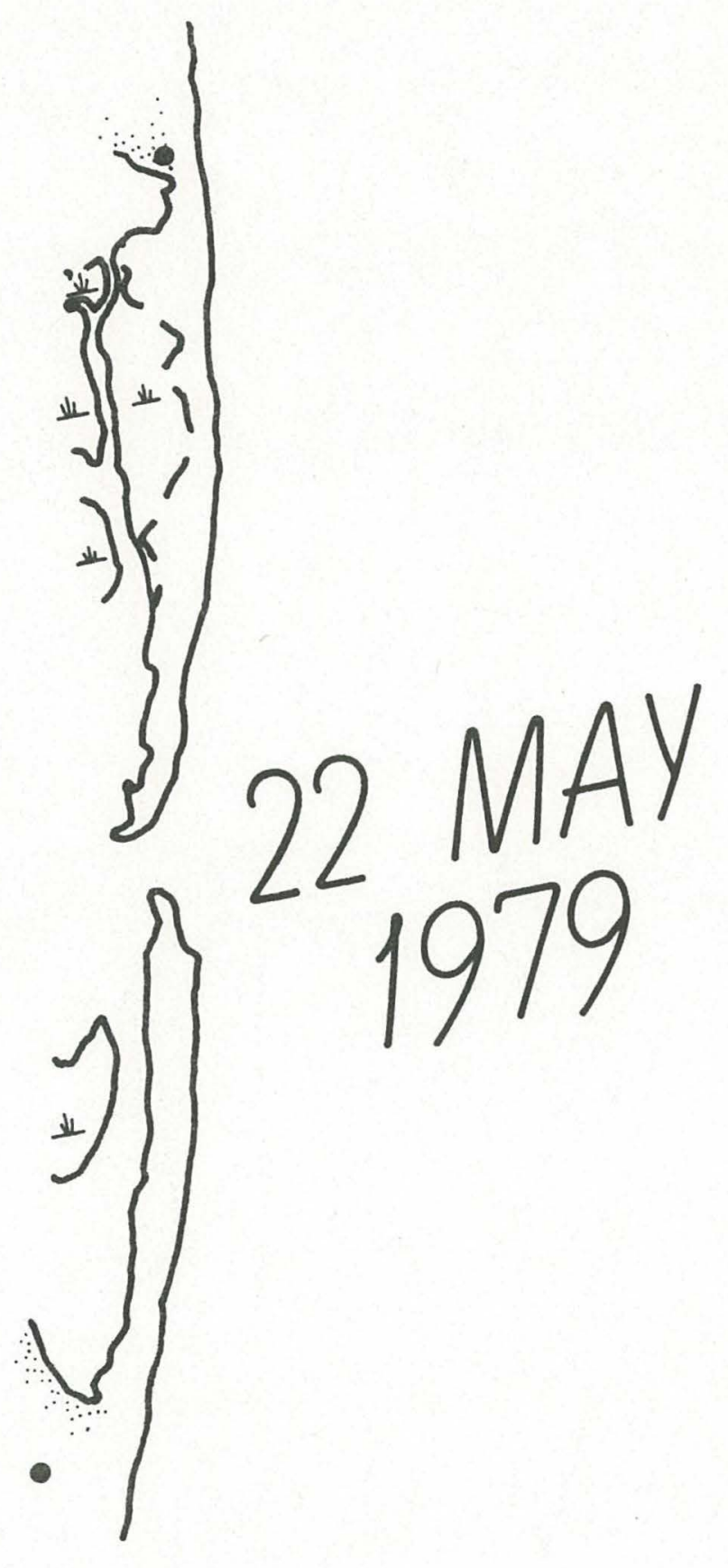

$-92-$ 
May 1982

DISTRIBUTION FOR SEA GRANT REPORTS

No. of Copies

3

5

25

1 $\underline{\text { Address }}$

National Sea Grant Depository

Pel1 Marine Science Library University of Rhode Is land

Kingston, RI 02881

Communications Specialist NOAA, Office of Sea Grant 6010 Executive Blyd.

Rockville, MD 20852

NOAA

Environmental Data \& Info. Serv., ESIC D812 11400 Rockville Pike Rockville, MD 20852

Sea Grant Today

Editor, Food Science and Technology VPI \& SU

B1acksburg, VA 24061 


\begin{tabular}{|c|c|c|}
\hline $\begin{array}{l}\text { REPORT DOCUMENTATION } \\
\text { PAGE }\end{array}$ & \begin{tabular}{|l|l|} 
1. REPORT NO. & 2. \\
\end{tabular} & 3. Recipient's Accession No. \\
\hline \multirow{2}{*}{\multicolumn{2}{|c|}{$\begin{array}{l}\text { 4. Titie and subeitie } \\
\text { BEACH CHANGES AT NAUSET INLET, CAPE COD, MASSACHUSETTS } \\
1670-1981\end{array}$}} & $\begin{array}{l}\text { 5. Report Date } \\
\text { August } 1982\end{array}$ \\
\hline & & 6. \\
\hline \multicolumn{2}{|c|}{$\begin{array}{l}\text { Author(s) } \\
\text { P.E. Speer, D.G. Aubrey and E. Ruder }\end{array}$} & 8. Performing Oreanization Rept. No. \\
\hline \multirow{2}{*}{\multicolumn{2}{|c|}{$\begin{array}{l}\text { 9. Perlorming Organization Name and Addrass } \\
\text { Woods Hole Oceanographic Institution } \\
\text { Woods Hole, Massachusetts } 02543\end{array}$}} & \multirow{2}{*}{$\begin{array}{l}\text { 10. Project/Task/Work Unit No. } \\
\text { 11. Contract(C) or Grant(G) No. } \\
\text { (C) } N A 80-A A-D-00077 \text { (R/B-2 } \\
\text { (G) } D A A G 29-87-K-0004\end{array}$} \\
\hline & & \\
\hline \multicolumn{2}{|c|}{ 12. Sponsoring Organization Name and Address } & \multirow[t]{2}{*}{ 13. Type of Report \& Period Covered } \\
\hline \multirow{2}{*}{\multicolumn{2}{|c|}{$\begin{array}{l}\text { NOAA, Office of Sea Grant } \\
\text { U.S. Army Research Office }\end{array}$}} & \\
\hline & & 14. \\
\hline
\end{tabular}

15. Supplementary Notes

This report should be cited as: Woods Hole Oceanog. Inst. Tech. Rept. WHOI-82-40.

16. Abstract (Limit: 200 words)

A historical study of barrier beach and inlet changes for the Nauset Inlet region, Cape Cod, Massachusetts, was performed to document patterns of beach and inlet change as a preliminary to designing and carrying out field studies of inlet sediment transport. 120 historical charts from 1670 and 125 sets of aerial photographs from 1938 formed the basis for this study. Specific aspects of barrier beach and inlet change addressed include onshore barrier beach movement, longshore tidal inlet migration, and longshore sand bypassing past the inlet. In an effort to correlate forcing events with barrier changes, an exhaustive study of the local storm climate was performed. Detailed treatment of the specific mechanisms responsible for Nauset Inlet migration episodes in a direction opposite the dominant littoral drift are treated in a companion paper by Aubrey, Speer, and Ruder (1982). Documentation of the data base available for the Nauset Area is presented herein as appendices.

17. Document Analysis a. Descriptors

1. Barrier beaches

2. Tidal inlets

3. Inlet bypassing

b. Identifiers/Open-Ended Terms

c. CosArI Field/Group

18. Avallability Statement

19. Security Class (This Report)

Unclassified

20. Security Class (This Page)
21. No. of Pages

92

22. Price 


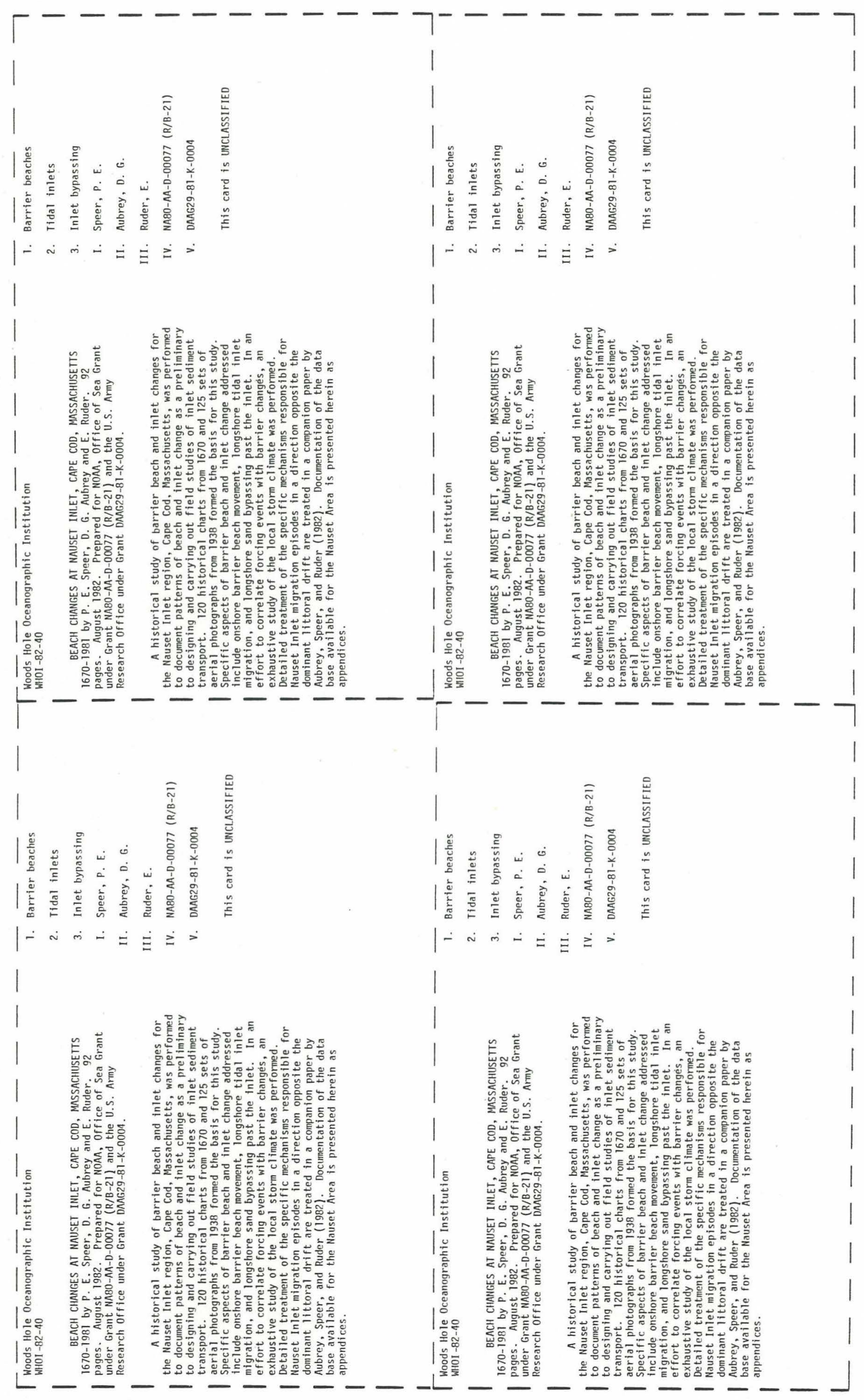

